\title{
Cleanup Verification Package for the 118-F-7, 100-F Miscellaneous Hardware Storage Vault
}

\author{
Prepared for the U.S. Department of Energy \\ by Washington Closure Hanford
}




\section{EXECUTIVE SUMMARY}

This cleanup verification package documents completion of remedial action for the 100-F, Miscellaneous Hardware Storage Vault (also referred to as the 118-F-7 site). The 118-F-7 site is located within the 100-FR-2 Operable Unit in the 100-F Area of the Hanford Site in southeastern Washington State. The site consisted of an inactive solid waste storage vault used from 1945 to 1965 for temporary storage of slightly contaminated reactor parts that could be recovered and reused for the 100-F Area reactor operations. The storage vault was approximately $23 \mathrm{~m}^{2}\left(247.5 \mathrm{ft}^{2}\right)$ and $2.4 \mathrm{~m}$ $(8 \mathrm{ft})$ deep and was covered with a wooden lid. The site was located south of the 105-F Reactor Building and east of the railroad line connecting to the 105-F Reactor Building.

Remediation of the 118-F-7 site was completed in April 2006. Remedial activities included complete removal of the storage vault, the wooden roof structure, and underlying contaminated soil. Results of the sampling, laboratory analyses, and data evaluations for the 118-F-7 site (which includes the remediation footprint, below cleanup level overburden [stockpiled soil], and the above cleanup level staging pile footprint) indicate that all remedial action objectives and goals for direct exposure, protection of groundwater, and protection of the Columbia River have been met (see Table ES-1).

The site meets cleanup standards and has been reclassified as "interim closed out" in accordance with the Hanford Federal Facility Agreement and Consent Order (Ecology et al. 1989) and the Waste Site Reclassification Guideline TPA-MP-14 (RL-TPA-90-0001) (DOE-RL 1998). A copy of the waste site reclassification form is included as Attachment ES-1. 


\section{Table ES-1. Summary of Cleanup Verification Results for the 118-F-7 Burial Ground. (2 Pages)}

\begin{tabular}{|c|c|c|c|c|}
\hline $\begin{array}{l}\text { Regulatory } \\
\text { Requirement }\end{array}$ & Remedial Action Goals & Results & $\begin{array}{l}\text { Remedial } \\
\text { Action } \\
\text { Objectives } \\
\text { Attained? }\end{array}$ & Ref. \\
\hline $\begin{array}{l}\text { Direct Exposure - } \\
\text { Radionuclides }\end{array}$ & $\begin{array}{l}\text { 1. Attain } 15 \mathrm{mrem} / \mathrm{yr} \text { dose rate } \\
\text { above background over } \\
1,000 \text { years. }\end{array}$ & $\begin{array}{l}\text { 1. Maximum activities for } \\
\text { cesium-137 and strontium-90 (the } \\
\text { only radionuclide COCs detected) } \\
\text { are below the cumulative } \\
15 \mathrm{mrem} / \mathrm{yr} \text { dose rate. }\end{array}$ & Yes & d,e \\
\hline $\begin{array}{l}\text { Direct Exposure- } \\
\text { Nonradionuclides }\end{array}$ & 1. Attain individual COC RAGs. & $\begin{array}{l}\text { 1. All individual COC concentrations } \\
\text { are below the direct exposure } \\
\text { criteria. }\end{array}$ & Yes & d,e \\
\hline \multirow{4}{*}{$\begin{array}{l}\text { Meet } \\
\text { Nonradionuclide } \\
\text { Risk } \\
\text { Requirements }\end{array}$} & $\begin{array}{l}\text { 1. Hazard quotient of }<1 \text { for } \\
\text { noncarcinogens. }\end{array}$ & $\begin{array}{l}\text { 1. All individual hazard quotients } \\
\text { are less than } 1 .\end{array}$ & \multirow{2}{*}{ Yes } & e \\
\hline & $\begin{array}{l}\text { 2. Cumulative hazard quotient of }<1 \\
\text { for noncarcinogens. }\end{array}$ & $\begin{array}{l}\text { 2. All cumulative hazard quotients } \\
\text { are less than } 1 .\end{array}$ & & e \\
\hline & $\begin{array}{l}\text { 3. Excess cancer risk of }<1 \times 10^{-6} \\
\text { for individual carcinogens. }\end{array}$ & $\begin{array}{l}\text { 3. Cadmium, the only carcinogenic } \\
\text { nonradionuclide COC for this site, } \\
\text { was not detected. }\end{array}$ & Yes & d,e \\
\hline & $\begin{array}{l}\text { 4. Attain a total excess cancer risk } \\
\text { of }<1 \times 10^{-5} \text { for carcinogens. }\end{array}$ & $\begin{array}{l}\text { 4. Cadmium, the only carcinogenic } \\
\text { nonradionuclide COC for this site, } \\
\text { was not detected. }\end{array}$ & Yes & d,e \\
\hline \multirow[t]{4}{*}{$\begin{array}{l}\text { Groundwater/ } \\
\text { River Protection - } \\
\text { Radionuclides }\end{array}$} & $\begin{array}{l}\text { 1. Attain single COC groundwater } \\
\text { and river protection RAGs. }\end{array}$ & $\begin{array}{l}\text { 1. Groundwater and river RAGs for } \\
\text { cesium- } 137 \text { and strontium- } 90 \text {, } \\
\text { have been attained. }\end{array}$ & \multirow[b]{2}{*}{ Yes } & d,e \\
\hline & $\begin{array}{l}\text { 2. Attain National Primary Drinking } \\
\text { Water Standards: } 4 \mathrm{mrem} / \mathrm{yr} \\
\text { (beta/gamma) dose rate to target } \\
\text { receptor/organs. }\end{array}$ & $\begin{array}{l}\text { 2. RESRAD modeling predicts that } \\
\text { residual concentrations of } \\
\text { cesium- } 137 \text { and strontium- } 90 \\
\text { meet the dose rate limit of } \\
4 \mathrm{mrem} / \mathrm{yr} \text {. }\end{array}$ & & d \\
\hline & $\begin{array}{l}\text { 3. Meet drinking water standards for } \\
\text { alpha emitters: the more } \\
\text { stringent of the } 15 \mathrm{pCi} / \mathrm{L} \mathrm{MCL} \\
\text { or } 1 / 25 \text { th of the derived } \\
\text { concentration guide per } \\
\text { DOE Order } 5400.5 . \text {. }^{\text {DO }}\end{array}$ & $\begin{array}{l}\text { 3. There are no alpha-emitting } \\
\text { COCs for this site. }\end{array}$ & NA & \\
\hline & $\begin{array}{l}\text { 4. Meet total uranium standard of } \\
21.2 \mathrm{pCi} / \mathrm{L} .\end{array}$ & $\begin{array}{l}\text { 4. Uranium is not a COC for this } \\
\text { site. }\end{array}$ & NA & \\
\hline
\end{tabular}




\section{Table ES-1. Summary of Cleanup Verification Results for the 118-F-7 Burial Ground. (2 Pages)}

\begin{tabular}{|c|c|c|c|c|}
\hline $\begin{array}{l}\text { Regulatory } \\
\text { Requirement }\end{array}$ & Remedial Action Goals & Results & $\begin{array}{l}\text { Remedial } \\
\text { Action } \\
\text { Objectives } \\
\text { Attained? }\end{array}$ & Ref. \\
\hline $\begin{array}{l}\text { Groundwater/ } \\
\text { River Protection - } \\
\text { Nonradionuclides }\end{array}$ & $\begin{array}{l}\text { 1. Attain individual nonradionuclide } \\
\text { groundwater and river cleanup } \\
\text { requirements. }\end{array}$ & $\begin{array}{l}\text { 1. Lead and copper exceeded } \\
\text { groundwater and/or river } \\
\text { protection RAGs. However, } \\
\text { results of the } 100 \text { Area } \\
\text { Analogous Sites RESRAD } \\
\text { Calculations (BHI 2005) } \\
\text { indicate that these constituents } \\
\text { will not reach groundwater } \\
\text { (and, therefore, the Columbia } \\
\text { River) within 1,000 years. } \\
\text { Therefore, the residual } \\
\text { concentrations achieve the } \\
\text { remedial action objectives for } \\
\text { groundwater and river } \\
\text { protection. }\end{array}$ & Yes & d \\
\hline $\begin{array}{l}\text { Other supporting } \\
\text { Information }\end{array}$ & \multicolumn{3}{|c|}{$\begin{array}{l}\text { 118-F-7 cleanup verification } 95 \% \text { UCL calculation (Appendix C). }{ }^{e} \\
118-F-7 \text { cleanup verification sample location design (Appendix C). }\end{array}$} & \\
\hline \multicolumn{5}{|c|}{ 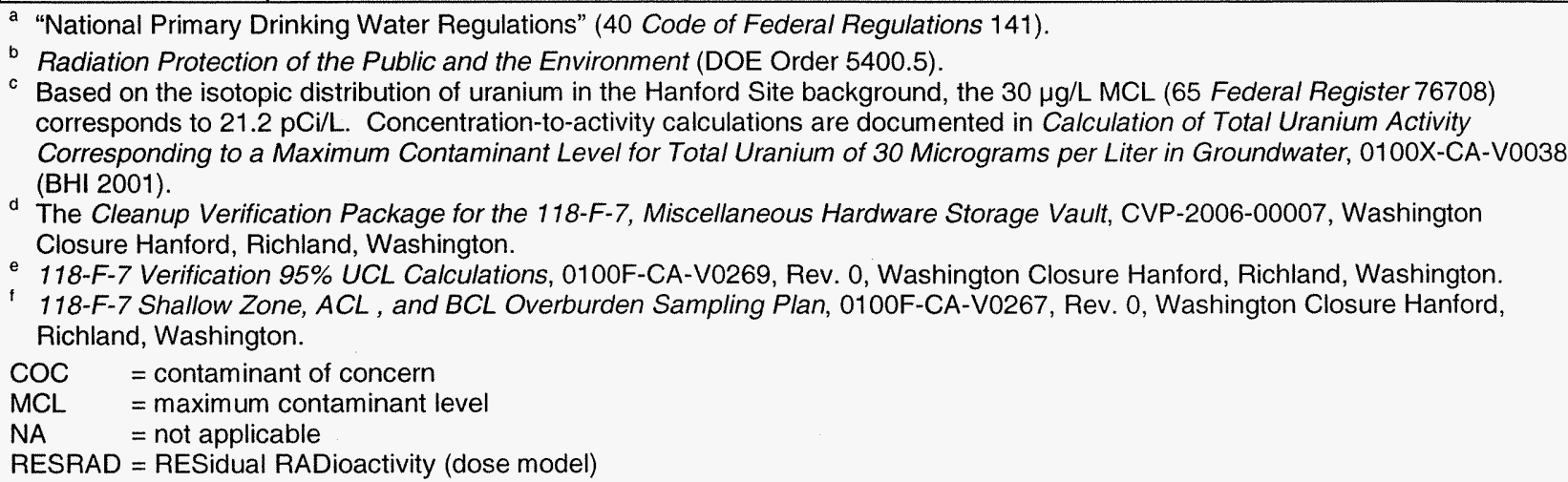 } \\
\hline
\end{tabular}


CVP-2006-00007

Rev. 0

ES-4 


\section{Attachment ES-1}

\section{Waste Site Reclassification Form}

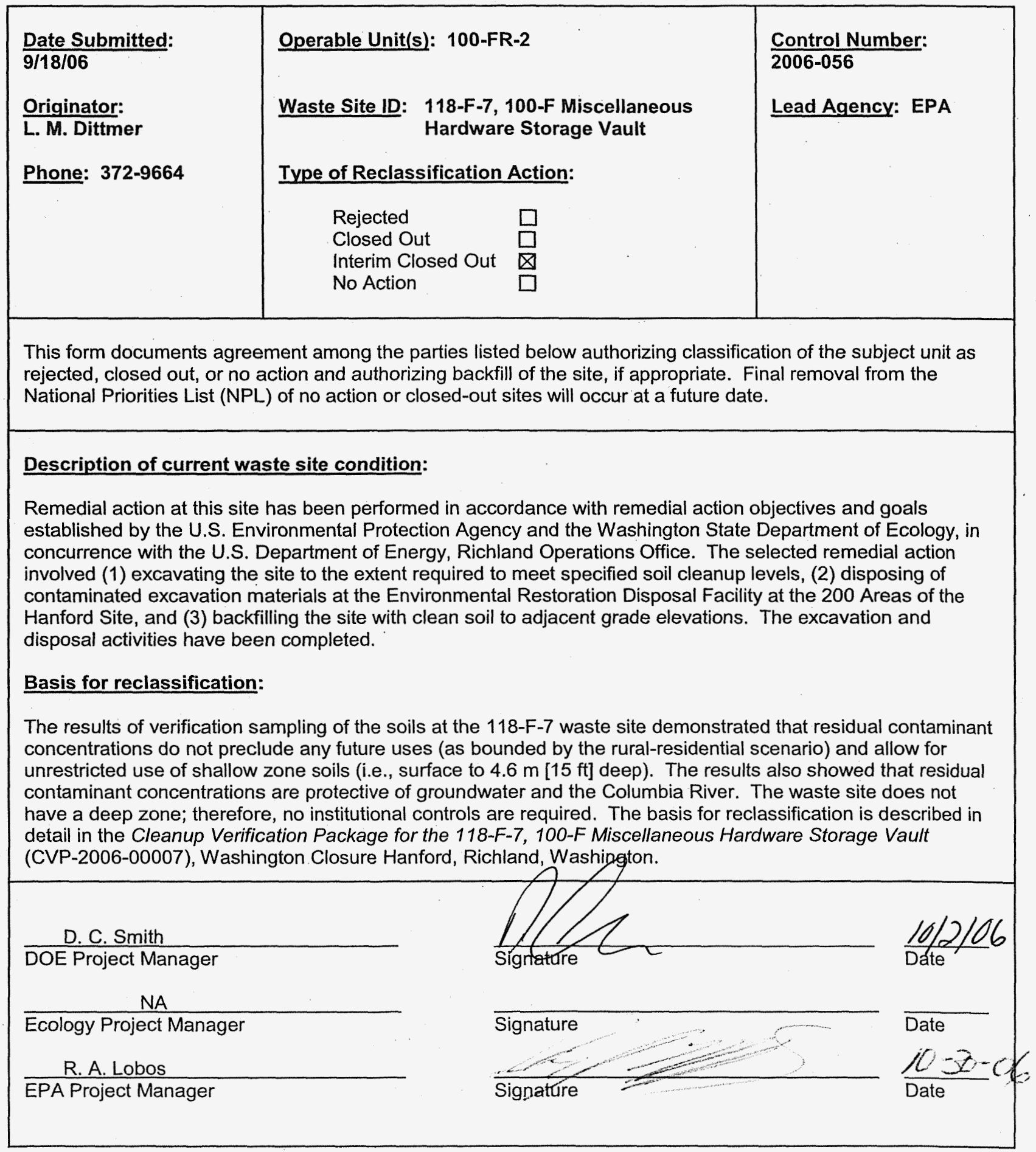


Rev. 0

ES-6 


\section{CONTENTS}

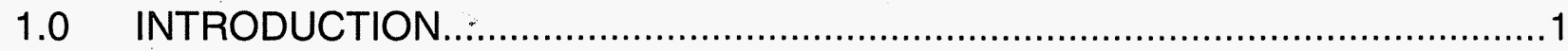

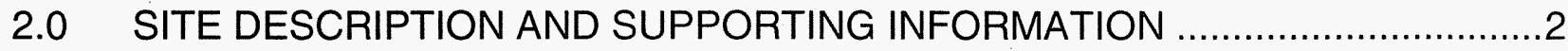

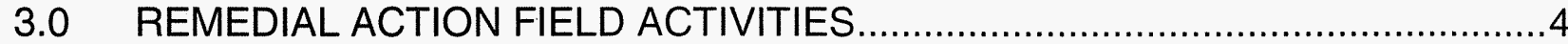

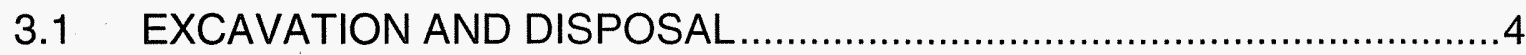

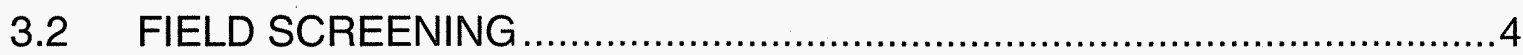

3.3 CLEANUP VERIFICATION SAMPLING AND ANALYSIS ....................

4.0 CLEANUP VERIFICATION DATA EVALUATION .....................................

$4.1 \quad$ DATA QUALITY ASSESSMENT PROCESS ...................................

4.2 CONTAMINANTS OF CONCERN 95\% UPPER CONFIDENCE LIMIT .....8

$4.3 \quad$ FOCUSED SAMPLE RESULTS .....................................................10

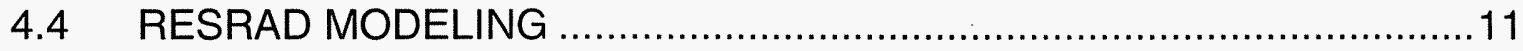

5.0 EVALUATION OF REMEDIAL ACTION GOAL ATTAINMENT …....................11

5.1 DIRECT EXPOSURE SOIL REMEDIAL ACTION GOALS ATTAINED ....12

5.1.1 Radionuclides ................................................................... 12

5.1.2 Nonradionuclides .............................................................. 13

5.2 GROUNDWATER REMEDIAL ACTION GOALS ATTAINED .................14

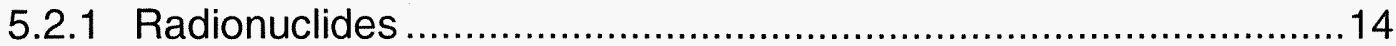

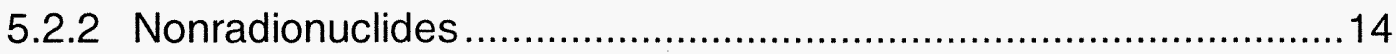

5.3 COLUMBIA RIVER REMEDIAL ACTION GOALS ATTAINED ...............16

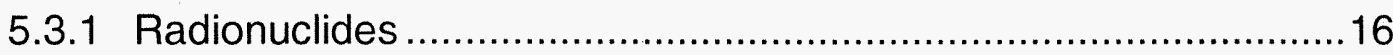

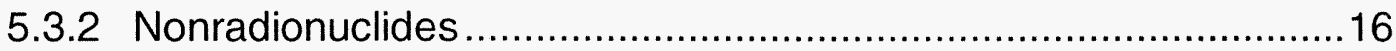

5.4 WAC 173-340 THREE-PART TEST FOR NONRADIONUCLIDES .........16

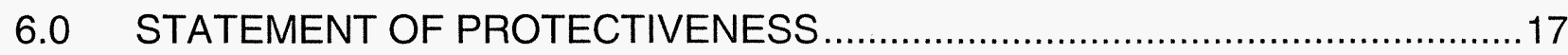

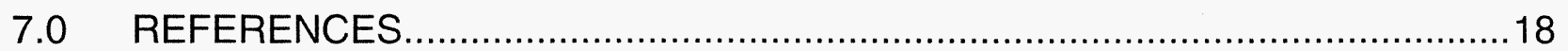

\section{APPENDICES}

A SUMMARY OF VERIFICATION SOIL SAMPLING AND ANALYTICAL RESULTS FOR THE 118-F-7 WASTE SITE CONTAMINANTS OF CONCERN

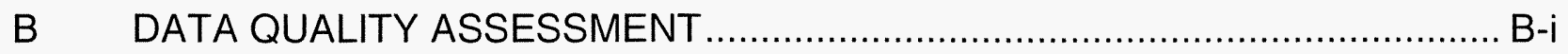

C CALCULATION BRIEF EXCERPTS …..................................................... C-

C1 118-F-7 Shallow Zone, ACL, and BCL Overburden Sampling Plan 0100F-CA-V0267 .......................................................................

C2 118-F-7 Cleanup Verification 95\% UCL Calculations, 0100F-CA-V0269

\section{FIGURES}

Figure 1. Hanford Site Map and 118-F-7 Site Plan. 
Figure 2. 118-F-7 Pre-Remediation Topographic Map............................................ 5

Figure 3. 118-F-7 Post-Remediation Topographic Map Showing Focused Sample Location.

Figure 4. GPRS Radiological Survey Gamma Track Map of the 118-F-7 Remediation Footprint (February 2, 2006).

\section{TABLES}

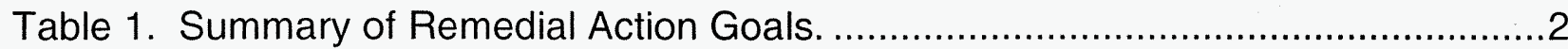

Table 2. Cleanup Verification Data Set................................................................

Table 3. Comparison of Focused Sample Results to Remedial Action Goals...............10

Table 4. Attainment of Radionuclide Direct Exposure RAG for the Shallow Zone Remediation Footprint.

Table 5. Attainment of Radionuclide Direct Exposure RAG for the ACL Staging Pile Footprint. 12

Table 6. Attainment of Nonradionuclide Direct Exposure Standards. (2 Pages)..........13

Table 7. Attainment of Nonradionuclide Remedial Action Goals for Protection of Groundwater and the Columbia River. (2 Pages).

Table 8. Application of the WAC 173-340 Three-Part Test. (2 Pages) 


\section{ACRONYMS AND ABBREVIATIONS}

ACL
BCL
COC
DQA
EPA
ERDF
RAG
RDR/RAWP
RESRAD
ROD
SAP
UCL
WAC

above cleanup level

below cleanup level

contaminant of concern

data quality assessment

U.S. Environmental Protection Agency

Environmental Restoration Disposal Facility

remedial action goal

remedial design report/remedial action work plan

RESidual RADioactivity dose assessment model

record of decision

sampling and analysis plan

upper confidence limit

Washington Administrative Code 


\section{$1.0 \quad$ INTRODUCTION}

The purpose of this cleanup verification package is to document that the 118-F-7 waste site was remediated in accordance with the Record of Decision for the 100-BC-1, 100-BC-2, 100-DR-1, 100-DR-2, 100-FR-2, 100-HR-2, and 100-KR-2 Operable Units, Hanford Site (100 Area Burial Grounds), Benton County, Washington (ROD) (EPA 2000). Remedial action objectives and goals for the 118-F-7 site were established by the U.S. Environmental Protection Agency (EPA) and the U.S. Department of Energy, Richland Operations Office, in concurrence with the Washington State Department of Ecology. These goals and objectives are documented in the 100 Area Burial Grounds ROD (EPA 2000) and the Remedial Design Report/Remedial Action Work Plan for the 100 Area (RDR/RAWP) (DOE-RL 2005). The ROD (EPA 2000) provides the U.S. Department of Energy, Richland Operations Office the authority, guidance, and objectives to conduct this remedial action.

The preferred remedy specified in the ROD (EPA 2000) and conducted for the 118-F-7 site included (1) excavating the site to the extent required to meet specified soil cleanup levels, (2) disposing of contaminated excavation materials at the Environmental Restoration Disposal Facility (ERDF) at the 200 Areas of the Hanford Site, and (3) backfilling the site with overburden (stockpiled soil) and clean soil to average adjacent grade elevation. Excavation was driven by remedial action objectives for direct exposure, protection of groundwater, and protection of the Columbia River. For the respective points of compliance, remedial action goals (RAGs) summarized in Table 1 were established for the radionuclide and nonradionuclide contaminants of concern (COCs). Waste site COCs were identified in the Remedial Design Report/Remedial Action Work Plan for the 100 Area (DOE-RL 2005) and are listed in Table 1. At the request of EPA cesium-137 and strontium-90 were added to the site verification $C O C$ list (WCH 2006). Additionally, copper was added as a COC as a result of a single detection above the RAGs within the above cleanup level (ACL) staging pile footprint.

Soil cleanup levels were established in the interim action ROD based on a limited ecological risk assessment. Although not required by the ROD (EPA 2000), a comparison against ecological risk screening levels has been made for the site COCs, as identified in the RDR/RAWP. Copper and lead exceeded screening level values; however, exceedance of screening values does not necessarily indicate the existence of risk to ecological receptors. The exceedance of soil screening values by lead and copper concentrations at the site will be evaluated in the context of additional lines of evidence for ecological effects. A baseline risk assessment for the river corridor portion of the Hanford Site began in 2004, which includes a more complete quantitative ecological risk assessment. That baseline risk assessment will be used as part of the final closeout decision for this site. 
Table 1. Summary of Remedial Action Goals.

\begin{tabular}{|c|c|c|c|}
\hline cocs & $\begin{array}{c}\text { Direct Exposure } \\
\text { RAG }\end{array}$ & $\begin{array}{c}\text { Groundwater } \\
\text { Protection RAG } \\
(p \mathrm{C} / \mathrm{L})\end{array}$ & $\begin{array}{l}\text { Columbia River } \\
\text { Protection RAG } \\
(\mathrm{pCi} / \mathrm{L})\end{array}$ \\
\hline \multicolumn{4}{|c|}{ Radionuclides } \\
\hline Cobalt- 60 & \multirow{4}{*}{$\begin{array}{l}15 \mathrm{mrem} / \mathrm{yr} \\
\text { (cumulative) }^{\mathrm{a}}\end{array}$} & \multirow{3}{*}{$\begin{array}{c}4 \mathrm{mrem} / \mathrm{yr} \\
\text { (cumulative) }^{\mathrm{b}}\end{array}$} & \multirow{3}{*}{$\begin{array}{c}4 \mathrm{mrem} / \mathrm{yr} \\
\text { (cumulative) }^{\mathrm{b}}\end{array}$} \\
\hline & & & \\
\hline Silver-108M & & & \\
\hline Strontium-90 & & $8^{c, d}$ & $8^{c, d}$ \\
\hline cOCs & $\begin{array}{c}\text { Direct Exposure } \\
\text { RAGs } \\
\text { (mg/kg) }\end{array}$ & $\begin{array}{c}\text { Soil RAG for } \\
\text { Groundwater Protection } \\
(\mathrm{mg} / \mathrm{kg})\end{array}$ & $\begin{array}{l}\text { Soil RAG for Columbia } \\
\text { River Protection } \\
\text { (mg/kg) }\end{array}$ \\
\hline \multicolumn{4}{|c|}{ Nonradionuclides } \\
\hline Cadmium & 13.9 & $0.81^{\mathrm{e}}$ & $0.81^{\mathrm{e}}$ \\
\hline Copper & 2,960 & 59.2 & $22.0^{\mathrm{e}}$ \\
\hline Lead & $353^{\dagger}$ & $10.2^{e}$ & $10.2^{e}$ \\
\hline \multicolumn{4}{|c|}{$\begin{array}{l}\text { Lookup values that correspond to the } 15 \mathrm{mrem} / \mathrm{yr} \text { dose rate are based on a generic site model and are } \\
\text { presented in the Remedial Design Report/Remedial Action Work Plan for the } 100 \text { Area (DOE-RL 2005). } \\
\text { b Lokup values based on individual radionuclide } 4 \mathrm{mrem} / \mathrm{yr} \text { dose rate equivalent for beta and gamma emitters per } \\
\text { national drinking water standards as presented in the } 100 \text { Area Burial Grounds Remedial Action Sampling and } \\
\text { Analysis Plan (DOE-RL 2001). Alpha emitters must meet drinking water standards based on the more } \\
\text { conservative of the } 15 \mathrm{pCi} / \mathrm{L} \text { maximum contaminant level or } 1 / 25 \text { th of the derived concentration guide per } \\
\text { DOE Order } 5400.5 \text {. } \\
\text { c Strontium-90 contributes to the } 4 \text { mrem/yr (cumulative) RAG for groundwater and river protection. } \\
\text { d Promulgated groundwater protection standard (40 CFR 141). } \\
\text { e Where cleanup levels are less than background, cleanup levels default to background (WAC 173-340-700[4][d]) } \\
\text { (1996). }\end{array}$} \\
\hline $\begin{array}{l}\text { COC }=\text { contaminant } \\
\text { RAG }=\text { remedial act } \\
\text { WAC }=\text { Washington }\end{array}$ & e Code & & \\
\hline
\end{tabular}

\subsection{SITE DESCRIPTION AND SUPPORTING INFORMATION}

The 118-F-7 site is located in the 100-FR-2 Operable Unit of the 100-F Area at the Hanford Site. The site is south of the 105-F Reactor Building and east of the railroad line connecting to the 105-F Reactor Building (Figure 1). This site was an inactive solid waste storage vault used from 1945 to 1965 for temporary storage of slightly contaminated reactor parts that could be recovered and reused for the 100-F Area reactor operations. The vault was a concrete box measuring approximately $23 \mathrm{~m}^{2}$

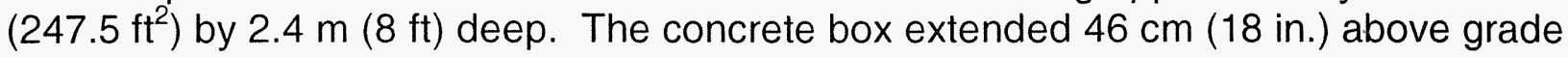
and was covered with a wooden lid. Underground Radioactive Material signs were posted on the wooden lid. 
Figure 1. Hanford Site Map and 118-F-7 Site Plan.

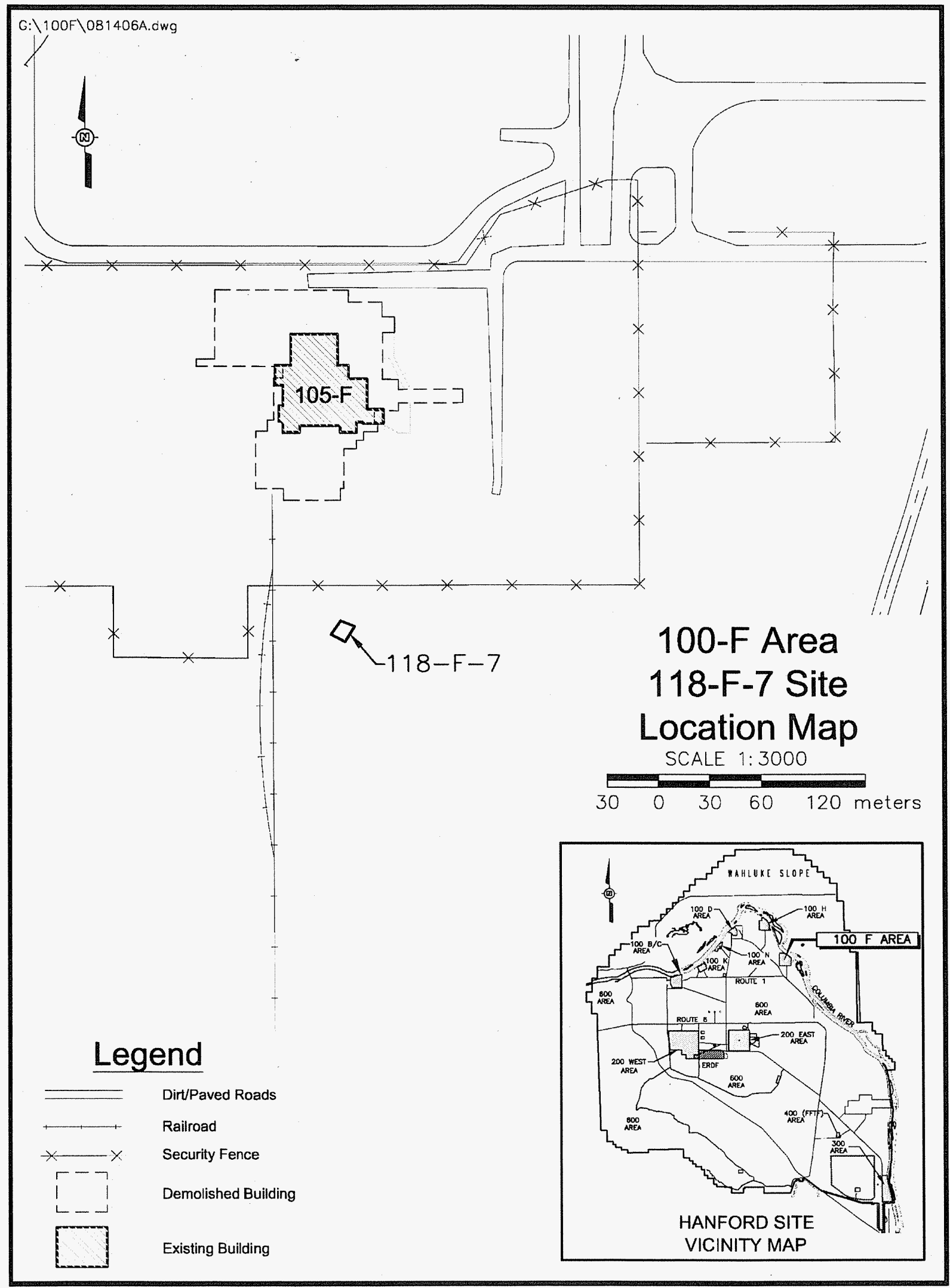


Rev. 0

\subsection{REMEDIAL ACTION FIELD ACTIVITIES}

\subsection{EXCAVATION AND DISPOSAL}

Remedial action at the 118-F-7 site began on January 31, 2006, with load out completed in April 2006. Excavation of the site involved removing the concrete vault structure, the wooden roof structure, and any underlying contaminated soil. A single lead/cadmium reactor poison piece, measuring $15 \mathrm{~cm}(6 \mathrm{in}$.) in length and $3.8 \mathrm{~cm}(1.5 \mathrm{in})$ in diameter, was discovered in the vault during excavation (WCH 2006). All contaminated materials were disposed at ERDF.

Pre- and post-remediation topographic maps are shown in Figures 2 and 3 , respectively. At the conclusion of excavation activities, the elevation at the bottom of the excavation was $123 \mathrm{~m}(403.5 \mathrm{ft})$. The excavation area was $138 \mathrm{~m}^{2}\left(1,487 \mathrm{ft}^{2}\right)$ with an approximate depth of $3.0 \mathrm{~m}(9.8 \mathrm{ft})$. An estimated 104 metric tons (115 U.S. tons) of material from the site was disposed at ERDF.

\subsection{FIELD SCREENING}

Radiological field screening was conducted during the site remedial actions as specified in the SAP (DOE-RL 2001). Field screening was used to guide the excavation to quickly assess the presence and level of contamination. Field screening at the site included using a radiological data mapping system survey. The radiological mapping survey was performed over more than $50 \%$ of the site excavation surface area using a Global Positioning Environmental Radiological Surveyor (GPERS). No significant levels of radiological activity were detected during the radiological field screening, as shown in Figure 4, and, therefore, no further remediation was required prior to collection of the final cleanup verification samples.

\subsection{CLEANUP VERIFICATION SAMPLING AND ANALYSIS}

Final cleanup verification samples were collected on June 5,2006 , to confirm acceptability of residual contaminant concentrations in the soil at the 118-F-7 waste site. The verification samples were submitted to offsite laboratories for analysis using approved EPA analytical methods, as required per the 100 Area Burial Grounds Remedial Action Sampling and Analysis Plan (SAP) (DOE-RL 2001). The 118-F-7 site was excavated to a depth of approximately $3 \mathrm{~m}(9.8 \mathrm{ft})$. Therefore, the 118-F-7. remediation excavation footprint was classified as one shallow zone decision unit based on its size and depth. The below cleanup level $(B C L)$ overburden (stockpiled soil) and the ACL staging pile footprint are separate shallow zone decision units. As specified in the SAP (DOE-RL 2001), four composite samples were collected from each of the waste site decision units, in addition to the single focused sample collected from beneath the location of the former vault. 
Figure 2. 118-F-7 Pre-Remediation Topographic Map.

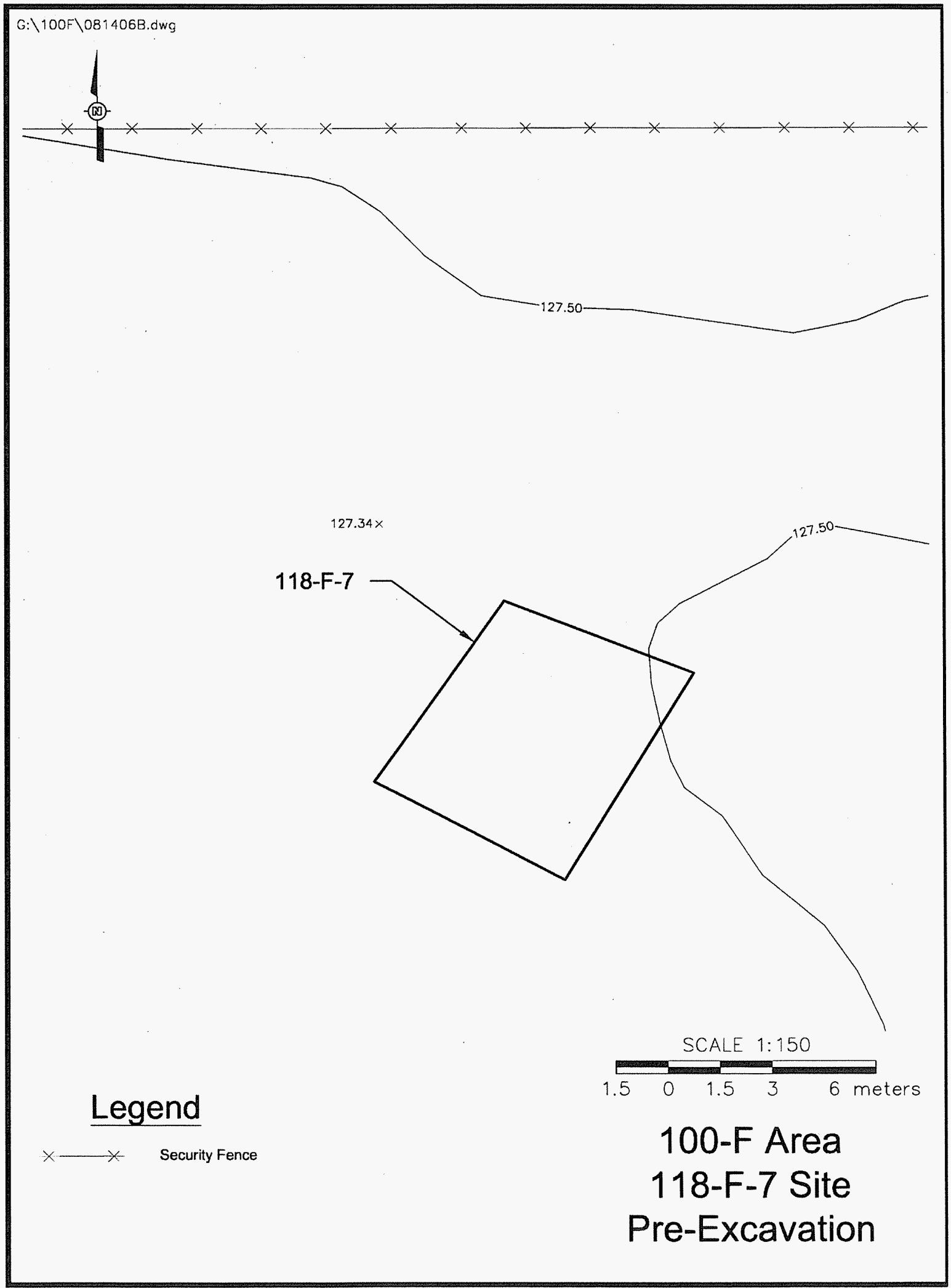


Figure 3. 118-F-7 Post-Remediation Topographic Map Showing Focused Sample Location.

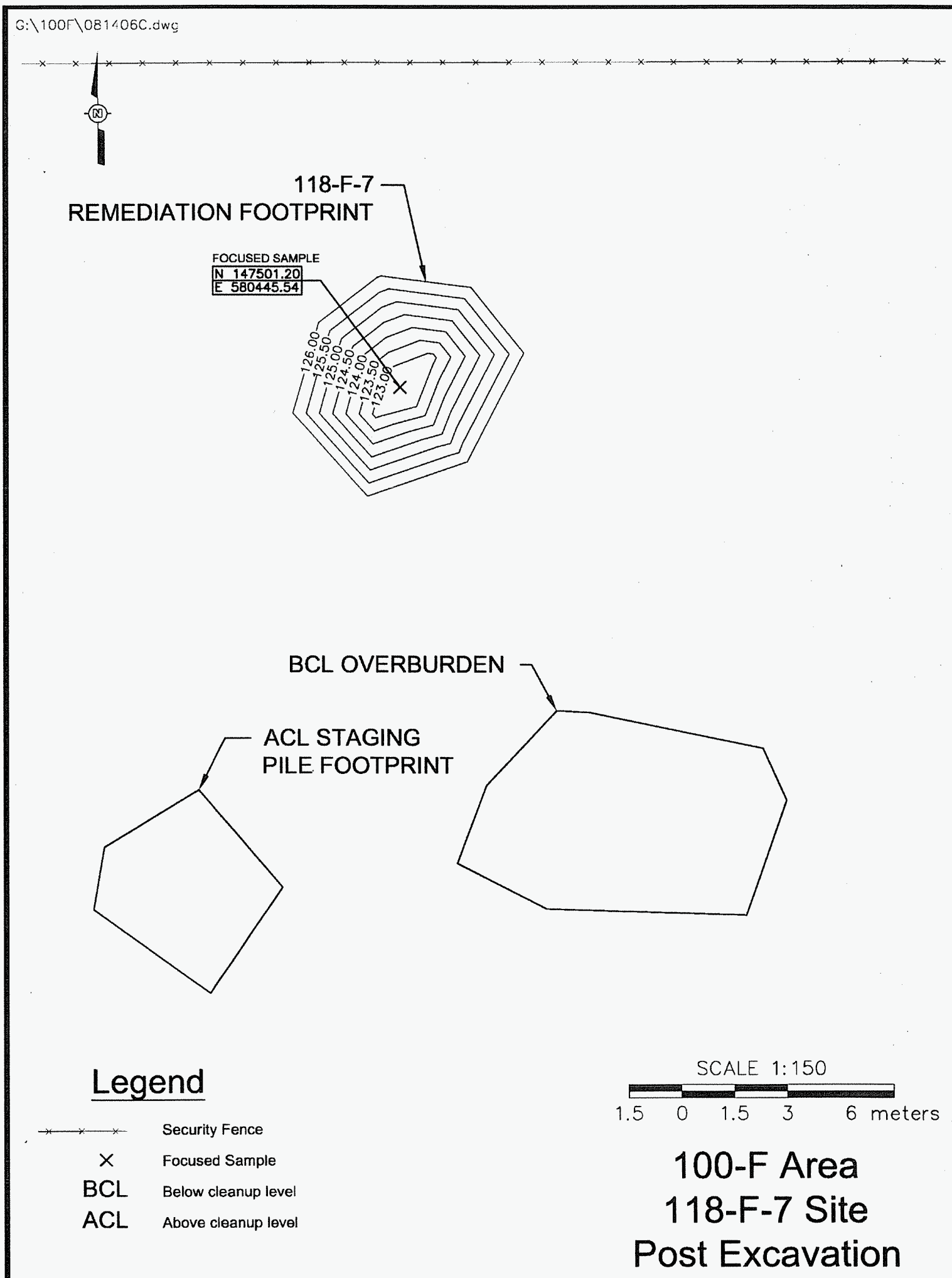




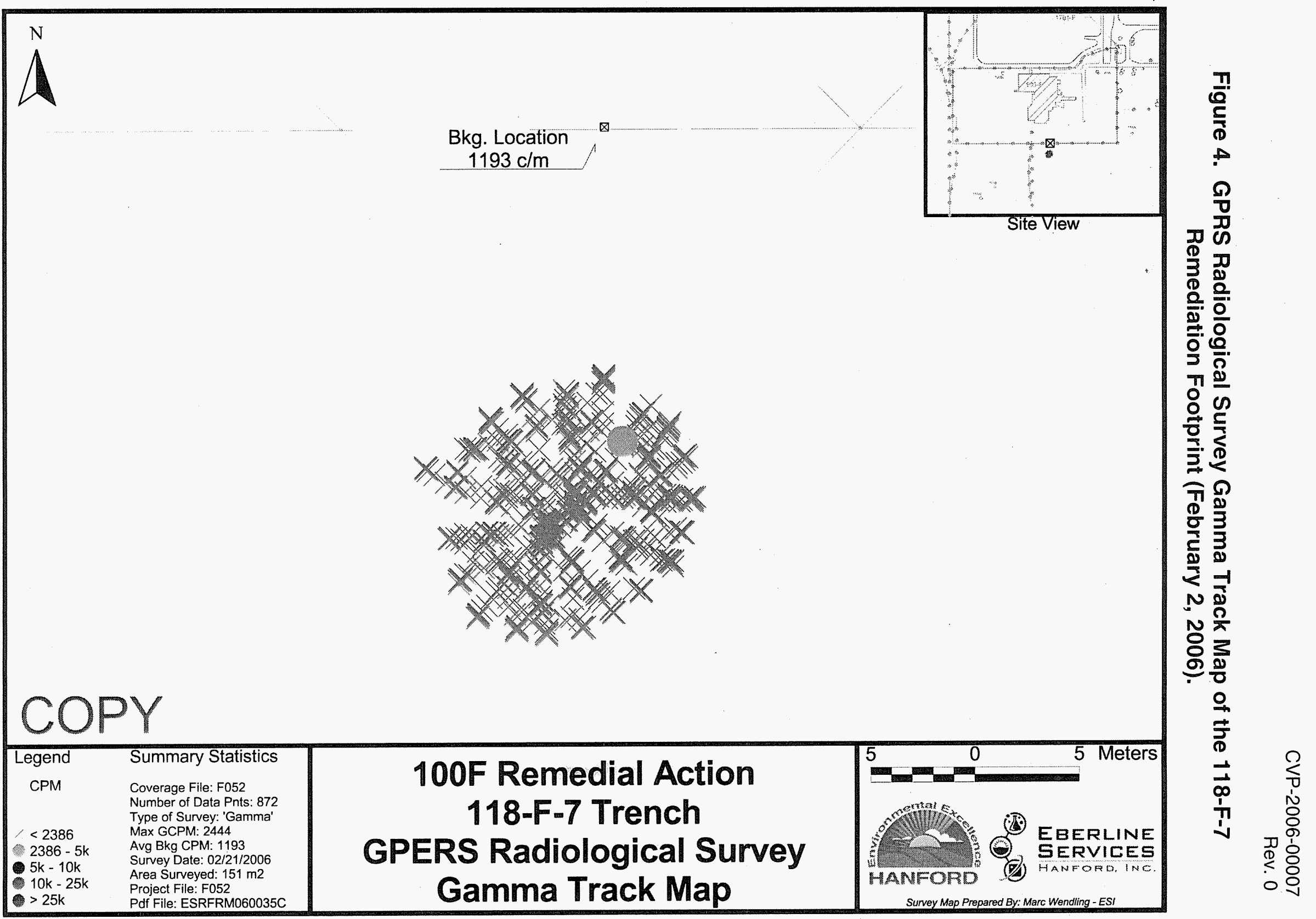


Verification sampling was performed by dividing each shallow zone decision unit (i.e., the excavation footprint, stockpiled soil, and $A C L$ staging pile footprint) into four sampling areas (A1, A2, A3, and A4) with the sampling areas further divided into16-node sample grids. One statistical verification sample was collected per sampling area by compositing soil collected at four randomly selected nodes. As such, each decision unit was represented by four composite statistical verification samples. Additionally, one focused soil sample was collected from the bottom of the remediation excavation beneath the location of the former vault. The sample design methodology and sample location figures are presented in the verification sample design calculation brief in Appendix C, and the location of the focused sample is provided in Figure 3.

\subsection{CLEANUP VERIFICATION DATA EVALUATION}

This section presents the evaluation and modeling of the 118-F-7 cleanup verification data for comparison with the data quality criteria and RAGs.

\subsection{DATA QUALITY ASSESSMENT PROCESS}

A data quality assessment (DQA) was performed to compare the verification sampling approach and resulting analytical data with the sampling and data quality requirements specified by the project objectives and performance specifications.

The DQA for the 118-F-7 site determined that the data are of the right type, quality, and quantity to support site verification decisions within specified error tolerances. All analytical data were found to be acceptable for decision-making purposes. The evaluation verified that the sample design was sufficient for the purpose of clean site verification. The cleanup verification sample analytical data are stored in the Environmental Restoration project-specific database for data evaluation prior to being submitted for inclusion in the Hanford Environmental Information System database. The verification data are summarized in Appendix $A$. The detailed DQA is presented in Appendix B.

\subsection{CONTAMINANTS OF CONCERN 95\% UPPER CONFIDENCE LIMIT}

The primary statistical calculation to support cleanup verification is the $95 \%$ upper confidence limit (UCL) on the arithmetic mean of the data. The $95 \% \mathrm{UCL}$ values for each $\mathrm{COC}$ are computed for each decision unit (e.g., for the shallow zone, BCL overburden [stockpiled soil], and ACL staging pile footprint). Prior to calculating the 95\% UCL, the individual sample results are reviewed and, as appropriate, adjusted per the SAP (DOE-RL 2001) and RDR/RAWP (DOE-RL 2005). This process is summarized below. 
For radionuclides, the laboratory-reported value is used in the calculation of the $95 \%$ UCL. In cases where the laboratory does not report a value for data qualified with a " $U$ " (i.e., less than the detection limit), one-half of the minimum detectable activity is used in the calculation of the $95 \%$ UCL. For nonradionuclides, a value equal to one-half the practical quantitation limit is used for data flagged with a "U" (i.e., less than the detection limit) in the calculation of the $95 \% \mathrm{UCL}$, as required by Washington Administrative Code (WAC) 173-340-740[7][g]. If greater than half of the sample results for a given nonradionuclide $\mathrm{COC}$ are below detection, the statistical value is set equal to the maximum concentration detected (i.e., versus computing a 95\% UCL).

Verification sampling summary statistics (95\% UCL values) are listed in Table 2. Individual sample cleanup verification results are presented in Appendix A. The columns on the left side of Table 2 are the COCs and the $95 \% \mathrm{UCL}$ values before subtraction of background. The fifth column of Table 2 presents the background, where values exist, and the last three columns present the statistical values adjusted for background, if appropriate, which becomes the cleanup verification data set used for further evaluation and modeling.

Table 2. Cleanup Verification Data Set.

\begin{tabular}{|c|c|c|c|c|c|c|c|}
\hline \multirow[b]{2}{*}{ cocs } & \multicolumn{3}{|c|}{$95 \%$ UCL Statistical Values ${ }^{\mathrm{a}}(\mathrm{pCi} / \mathrm{g})$} & \multirow[b]{2}{*}{$\begin{array}{l}\text { Hanford Site } \\
\text { Background } \\
\quad(p C i / g)\end{array}$} & \multicolumn{3}{|c|}{ Cleanup Verification Data Set ${ }^{c}(\mathrm{pCi} / \mathrm{g})$} \\
\hline & $\begin{array}{l}\text { Shallow } \\
\text { Zone }\end{array}$ & $\begin{array}{c}\mathrm{BCL} \\
\text { Overburden }\end{array}$ & $\begin{array}{c}\mathrm{ACL} \\
\text { Staging } \\
\text { Pile } \\
\text { Footprint }\end{array}$ & & $\begin{array}{l}\text { Shallow } \\
\text { Zone }\end{array}$ & $\begin{array}{c}B C L \\
\text { Overburden }\end{array}$ & $\begin{array}{c}\text { ACL } \\
\text { Staging } \\
\text { Pile } \\
\text { Footprint }\end{array}$ \\
\hline Cobalt -60 & $\begin{array}{l}0.230 \\
\text { (ND) }\end{array}$ & $\begin{array}{l}0.190 \\
\text { (ND) }\end{array}$ & $0.150(\mathrm{ND})$ & 0.008 & $\begin{array}{l}0.230 \\
\text { (ND) }\end{array}$ & $\begin{array}{l}0.182 \\
\text { (ND) }\end{array}$ & $\begin{array}{l}0.150 \\
\text { (ND) }\end{array}$ \\
\hline Cesium-137 & 0.301 & $\begin{array}{l}0.0587 \\
\text { (ND) }\end{array}$ & 0.205 & 1.1 & 0.301 & $\begin{array}{c}0 \text { (<BG) } \\
\text { (ND) }\end{array}$ & 0.205 \\
\hline Silver-108m & $\begin{array}{c}0.0351 \\
\text { (ND) }\end{array}$ & $\begin{array}{c}0.0281 \\
\text { (ND) }\end{array}$ & $\begin{array}{l}0.0298 \\
\text { (ND) }\end{array}$ & NA & $\begin{array}{l}0.0351 \\
\text { (ND) }\end{array}$ & $\begin{array}{c}0.0281 \\
\text { (ND) }\end{array}$ & $\begin{array}{l}0.0298 \\
\text { (ND) }\end{array}$ \\
\hline Strontium-90 & 0.183 & $\begin{array}{l}0.0418 \\
\text { (ND) }\end{array}$ & 0.573 & 0.18 & 0.183 & $\begin{array}{c}0(<B G) \\
(N D)\end{array}$ & 0.573 \\
\hline \multirow[b]{2}{*}{ cocs } & \multicolumn{3}{|c|}{$95 \%$ UCL Statistical Values ${ }^{a}(\mathrm{mg} / \mathrm{kg})$} & \multirow[b]{2}{*}{$\begin{array}{l}\text { Hanford Site } \\
\text { Background } \\
(\mathrm{mg} / \mathrm{kg})\end{array}$} & \multicolumn{3}{|c|}{ Cleanup Verification Data Set $(\mathrm{mg} / \mathrm{kg})$} \\
\hline & $\begin{array}{c}\text { Shallow } \\
\text { Zone }\end{array}$ & $\begin{array}{c}B C L \\
\text { Overburden }\end{array}$ & $\begin{array}{c}\text { ACL } \\
\text { Staging } \\
\text { Pile } \\
\text { Footprint }\end{array}$ & & $\begin{array}{c}\text { Shallow } \\
\text { Zone }\end{array}$ & $\begin{array}{c}\mathrm{BCL} \\
\text { Overburden }\end{array}$ & $\begin{array}{c}\text { ACL } \\
\text { Staging } \\
\text { Pile } \\
\text { Footprint }\end{array}$ \\
\hline Cadmium & $\begin{array}{l}0.21 \\
(\mathrm{ND}) \\
\end{array}$ & $\begin{array}{l}0.21 \\
\text { (ND) } \\
\end{array}$ & $\begin{array}{l}0.21 \\
\text { (ND) } \\
\end{array}$ & $0.81^{\mathrm{d}}$ & $\begin{array}{l}0.21 \\
\text { (ND) } \\
\end{array}$ & $\begin{array}{l}0.21 \\
\text { (ND) } \\
\end{array}$ & $\begin{array}{l}0.21 \\
\text { (ND) } \\
\end{array}$ \\
\hline Copper & 12.2 & 10.8 & 369 & 22.0 & 12.2 & 10.8 & 369 \\
\hline Lead & 10.9 & 5.2 & 25.4 & 10.2 & 10.9 & 5.2 & 25.4 \\
\hline
\end{tabular}

a The shallow zone, ACL staging pile footprint, and BCL overburden are from the 118-F-7 Cleanup Verification $95 \%$ UCL Calculations, 0100F-CA-V0269, Rev. 0, Refer to Appendix C for additional details on determination of statistical values.

b Represents the 90th percentile of the lognormal distribution (DOE-RL 1996).

c For overburden (stockpiled soil) the anthropogenic background (DOE-RL 1996) and naturally occurring background is subtracted from all radionuclides. For other decision units (i.e., shallow zone and ACL staging pile footprint), only naturally occurring background (uranium) is subtracted. Refer to the $95 \%$ UCL calculation brief in Appendix C for additional details on determination of statistical values. 
Table 2. Cleanup Verification Data Set.

\begin{tabular}{|c|c|c|c|c|c|c|c|}
\hline \multirow[b]{2}{*}{ cocs } & \multicolumn{3}{|c|}{$95 \%$ UCL Statistical Values ${ }^{a}(\mathrm{pCi} / \mathrm{g})$} & \multirow[b]{2}{*}{$\begin{array}{l}\text { Hanford Site } \\
\text { Background }^{\mathrm{b}} \\
(\mathrm{pCi} / \mathrm{g})\end{array}$} & \multicolumn{3}{|c|}{ Cleanup Verification Data Set $^{c}(\mathrm{pCi} / \mathrm{g})$} \\
\hline & $\begin{array}{c}\text { Shallow } \\
\text { Zone }\end{array}$ & $\begin{array}{c}\mathrm{BCL} \\
\text { Overburden }\end{array}$ & $\begin{array}{c}\text { ACL } \\
\text { Staging } \\
\text { Pile } \\
\text { Footprint }\end{array}$ & & $\begin{array}{l}\text { Shallow } \\
\text { Zone }\end{array}$ & $\begin{array}{c}\mathrm{BCL} \\
\text { Overburden }\end{array}$ & $\begin{array}{c}\text { ACL } \\
\text { Staging } \\
\text { Pile } \\
\text { Footprint }\end{array}$ \\
\hline
\end{tabular}

Hanford Site-specific background value is not available; not evaluated during background study. Value used is from Natural Background Soil Metals Concentrations in Washington State (Ecology 1994).

$\mathrm{ACL}=$ above cleanup level

$\mathrm{BCL}=$ below cleanup level

$\mathrm{NA}=$ not applicable

$\mathrm{COC}=$ contaminant of concern

$\mathrm{ND}=$ not detected (in all samples in the data set)

$\mathrm{UCL}=$ upper confidence limit

\subsection{FOCUSED SAMPLE RESULTS}

One focused sample was collected from the bottom of the excavation underlying the former concrete vault structure and analyzed for the site COCs. Statistical analysis (e.g., calculation of a $95 \% \mathrm{UCL}$ value) is inappropriate to use for evaluation of the focused sample; therefore, the sample results are evaluated using a direct comparison of the detected values to the cleanup levels. Table 3 provides a comparison of the focused sample results against the cleanup criteria.

Table 3. Comparison of Focused Sample Results to Remedial Action Goals.

\begin{tabular}{|c|c|c|c|c|c|c|}
\hline \multirow[b]{2}{*}{ cocs } & \multirow[b]{2}{*}{$\begin{array}{l}\text { Maximum } \\
\text { Result } \\
\text { (pCi/g) }\end{array}$} & \multicolumn{3}{|c|}{ Generic Site Lookup Values ${ }^{\mathrm{a}}(\mathrm{pCi} / \mathrm{g})$} & \multirow[b]{2}{*}{$\begin{array}{l}\text { Does the } \\
\text { Maximum } \\
\text { Result } \\
\text { Exceed } \\
\text { Lookup } \\
\text { values? }\end{array}$} & \multirow[b]{2}{*}{$\begin{array}{c}\text { Does the } \\
\text { Maximum } \\
\text { Result } \\
\text { Pass } \\
\text { Modeling? }\end{array}$} \\
\hline & & $\begin{array}{l}\text { Shallow } \\
\text { Zone } \\
\text { Lookup } \\
\text { Value }^{\mathrm{b}}\end{array}$ & $\begin{array}{c}\text { Soil } \\
\text { Concentration } \\
\text { for } \\
\text { Groundwater } \\
\text { Protection }\end{array}$ & $\begin{array}{c}\text { Soil } \\
\text { Concentration } \\
\text { for River } \\
\text { Protection }\end{array}$ & & \\
\hline Cesium-137 & $0.110(\mathrm{ND})$ & 6.2 & $1,465^{c}$ & $1,465^{\mathrm{C}}$ & No & NA \\
\hline Cobalt- 60 & $0.180(N D)$ & 1.4 & $13,900^{c}$ & $13,900^{c}$ & No & NA \\
\hline Silver-108m & 0.0590 (ND) & $2.38^{d}$ & $N V^{d}$ & $N V^{d}$ & No & NA \\
\hline Strontium-90 & $0.168(\mathrm{ND})$ & 4.5 & $27.6^{c}$ & $27.6^{\mathrm{e}}$ & No & NA \\
\hline \multirow[b]{2}{*}{ cocs } & \multirow[b]{2}{*}{$\begin{array}{c}\text { Maximum } \\
\text { Result } \\
\text { (mg/kg) }\end{array}$} & \multicolumn{3}{|c|}{ Remedial Action Goals ${ }^{a}$ (mg/kg) } & \multirow[b]{2}{*}{$\begin{array}{l}\text { Does the } \\
\text { Maximum } \\
\text { Result } \\
\text { Exceed } \\
\text { RAGs? }\end{array}$} & \multirow[b]{2}{*}{$\begin{array}{c}\text { Does the } \\
\text { Maximum } \\
\text { Result } \\
\text { Pass } \\
\text { Modeling? }\end{array}$} \\
\hline & & $\begin{array}{c}\text { Direct } \\
\text { Exposure }\end{array}$ & $\begin{array}{c}\text { Soil } \\
\text { Concentration } \\
\text { for } \\
\text { Groundwater } \\
\text { Protection }\end{array}$ & $\begin{array}{c}\text { Soil } \\
\text { Concentration } \\
\text { for River } \\
\text { Protection }\end{array}$ & & \\
\hline Cadmium $^{\mathrm{e}}$ & 0.21 (ND) & 13.9 & $0.81^{\dagger}$ & $0.81^{\dagger}$ & No & NA \\
\hline Copper & 11.3 & 2960 & 59.2 & $22.0^{f}$ & No & NA \\
\hline Lead & 63.8 & 353 & $10.2^{\dagger}$ & $10.2^{f}$ & Yes & $\mathrm{Yes}^{\mathrm{g}}$ \\
\hline
\end{tabular}


Table 3. Comparison of Focused Sample Results to Remedial Action Goals.

\begin{tabular}{|c|c|c|c|c|c|c|}
\hline \multirow[b]{2}{*}{ cocs } & \multirow[b]{2}{*}{$\begin{array}{l}\text { Maximum } \\
\text { Result } \\
(\mathrm{pCi} / \mathrm{g})\end{array}$} & \multicolumn{3}{|c|}{ Generic Site Lookup Values ${ }^{a}(\mathrm{pCi} / \mathrm{g})$} & \multirow[b]{2}{*}{$\begin{array}{c}\text { Does the } \\
\text { Maximum } \\
\text { Result } \\
\text { Exceed } \\
\text { Lookup } \\
\text { values? }\end{array}$} & \multirow[b]{2}{*}{$\begin{array}{c}\text { Does the } \\
\text { Maximum } \\
\text { Result } \\
\text { Pass } \\
\text { Modeling? }\end{array}$} \\
\hline & & $\begin{array}{l}\text { Shallow } \\
\text { Zone } \\
\text { Lookup } \\
\text { Value }^{b}\end{array}$ & $\begin{array}{c}\text { Soil } \\
\text { Concentration } \\
\text { for } \\
\text { Groundwater } \\
\text { Protection }\end{array}$ & $\begin{array}{c}\text { Soil } \\
\text { Concentration } \\
\text { for River } \\
\text { Protection }\end{array}$ & & \\
\hline
\end{tabular}

${ }^{a}$ Lookup values and RAGs obtained from the Remedial Design Report/Remedial Action Work Plan for the 100 Area (100 Area RDR/RAWP) (DOE-RL 2005) or calculated per WAC 173-340-720, WAC 173-340-730, and WAC 173-340-740, Method B, 1996, unless otherwise noted.

b. Activity corresponding to a single-radionuclide $15 \mathrm{mrem} / \mathrm{yr}$ exposure as calculated using a generic RESRAD model (DOE-RL 2005).

C Revised lookup value per 100 Area Radionuclide and Nonradionuclide Lookup Values for the 1995 Interim Remedial Action Record of Decision (BHI 2004).

d Radionuclide was not included in the 100 Area RDR/RAWP (DOE-RL 2005); lookup value presented obtained from 100 Area Radionuclide and Nonradionuclide Lookup Values for the 1995 Interim Remedial Action Record of Decision (BHI 2004).

e Hanford Site-specific background value is not available; not evaluated during background study. Value used is from Natural Background Soil Metals Concentrations in Washington State (Ecology 1994).

+ Where cleanup levels are less than background, cleanup levels default to background (WAC 173-340-700[4][d]) (1996).

9 Based on 100 Area Analogous Sites RESRAD Calculations (BHI 2005), with a groundwater table elevation of $114 \mathrm{~m}(374 \mathrm{ft})$ and a clean zone extending from groundwater to an elevation of $123 \mathrm{~m}(404 \mathrm{ft})$ lead is not predicted to reach groundwater within 1,000 years.

$\mathrm{COC}=$ contaminant of concern

$\mathrm{NA}=$ not applicable

$\mathrm{ND}=$ not detected

NV $=$ no value

$$
\begin{aligned}
& \text { RAG }=\text { remedial action goal } \\
& \text { RESRAD }=\text { RESidual RADioactivity (dose model) } \\
& \text { WAC }=\text { Washington Administrative Code }
\end{aligned}
$$

\subsection{RESRAD MODELING}

A site-specific RESidual RADioactivity (RESRAD) model was not developed for the 118-F-7 waste site. The statistical sampling results, shown in Table 2 , meet the remedial action goals summarized in Table 1. Additionally, no radionuclides were detected in the focused soil sample, as shown in Table 3.

\subsection{EVALUATION OF REMEDIAL ACTION GOAL ATTAINMENT}

This section demonstrates that remedial actions at the 118-F-7 site have achieved the applicable RAGs. Sections 5.1, 5.2, and 5.3 address attainment of direct exposure RAGs, groundwater protection RAGs, and Columbia River protection RAGs, respectively. Section 5.4 documents application of the WAC 173-340 three-part test to the shallow zone, BCL overburden (stockpiled soil), and the ACL staging pile footprint. This test is required for nonradionuclide COCs only and is based on the most restrictive RAG for each zone. 


\subsection{DIRECT EXPOSURE SOIL REMEDIAL ACTION GOALS ATTAINED}

\subsubsection{Radionuclides}

Cesium-137 and strontium-90 were the only radionuclide COCs detected in the shallow zone remediation footprint and $A C L$ staging pile footprint. The cumulative radionuclide dose was calculated separately for the shallow zone remediation footprint and ACL staging pile footprint, using the sum-of-fractions method as shown in Tables 4 and 5 . The columns on the left side of Tables 4 and 5 are the COCs and the $95 \%$ UCL values. The third column of Tables 4 and 5 presents the single radionuclide $15 \mathrm{mrem} / \mathrm{yr}$ dose-equivalence activity, and the last column presents the statistical values divided by the dose-equivalence activity. The cumulative dose $(1.4 \mathrm{mrem} / \mathrm{yr})$ for the shallow zone remediation footprint is less than the $15 \mathrm{mrem} / \mathrm{yr}$ RAG. The cumulative dose (2.4 mrem/yr) for the ACL staging pile footprint is also less than the $15 \mathrm{mrem} / \mathrm{yr}$ RAG.

Table 4. Attainment of Radionuclide Direct Exposure RAG for the Shallow Zone Remediation Footprint.

\begin{tabular}{|c|c|c|c|}
\hline $\begin{array}{l}\text { Contaminants of } \\
\text { Potential Concern }\end{array}$ & $\begin{array}{c}\text { Maximum } \\
\text { Activity }(\mathrm{pCi} / \mathrm{g})\end{array}$ & $\begin{array}{c}\text { Activity Equivalent } \\
\text { to } 15 \mathrm{mrem} / \mathrm{yr} \\
\text { Dose }(\mathrm{pCi} / \mathrm{g})\end{array}$ & Fraction \\
\hline Cesium-137 & 0.301 & 6.2 & 0.049 \\
\hline Strontium-90 & 0.183 & 4.5 & 0.041 \\
\hline \multicolumn{3}{|r|}{ Sum of Fractions } & 0.090 \\
\hline \multicolumn{3}{|c|}{ Equivalent Dose (mrem/yr) } & 1.4 \\
\hline
\end{tabular}

Table 5. Attainment of Radionuclide Direct Exposure RAG for the ACL Staging Pile Footprint.

\begin{tabular}{|l|c|c|c|}
\hline $\begin{array}{c}\text { Contaminants of } \\
\text { Potential Concern }\end{array}$ & $\begin{array}{c}\text { Maximum } \\
\text { Activity (pCi/g) }\end{array}$ & $\begin{array}{c}\text { Activity Equivalent } \\
\text { to } 15 \text { mrem/yr } \\
\text { Dose (pCi/g) }\end{array}$ & Fraction \\
\hline Cesium-137 & 0.205 & 6.2 & 0.033 \\
\hline Strontium-90 & 0.573 & 4.5 & 0.127 \\
\hline \multicolumn{3}{r|}{ Equivalent Dose (mrem/yr) } & 2.4 \\
\hline
\end{tabular}

The statistical values for the BCL overburden (stockpiled soil) radionuclide COCs were either not detected or detected below the statistical background levels as reported in the Hanford Site Background: Part 2, Soil Background for Radionuclides (DOE-RL 1996). No radionuclide COCs were detected in the focused sample collected from the bottom of the remediation excavation. All applicable radionuclide RAGs have been met for direct exposure at the 118-F-7 waste site. 


\subsubsection{Nonradionuclides}

5.1.2.1 Direct Comparison to RAGs. Table 6 compares the cleanup verification statistical values presented in Tables 2 and 3 to the direct exposure RAGs presented in Table 1. All residual concentrations are below the direct exposure RAG, and as such all applicable nonradionuclide RAGs have been meet for direct exposure.

Table 6. Attainment of Nonradionuclide Direct Exposure Standards. (2 Pages)

\begin{tabular}{|c|c|c|c|}
\hline Nonradionuclides & $\begin{array}{l}\text { Cleanup Verification } \\
\text { Data Set }(\mathrm{mg} / \mathrm{kg})\end{array}$ & $\begin{array}{l}\text { Direct Exposure RAG } \\
(\mathrm{mg} / \mathrm{kg})\end{array}$ & $\begin{array}{l}\text { Direct Exposure RAGs } \\
\text { Attained? }^{\mathrm{b}}\end{array}$ \\
\hline \multicolumn{4}{|c|}{ Shallow Zone } \\
\hline Cadmium & 0.21 (ND) & 13.9 & Yes \\
\hline Copper & 12.2 & 2,960 & Yes \\
\hline Lead & 10.9 & 353 & Yes \\
\hline \multicolumn{4}{|c|}{$B C L$ Overburden } \\
\hline Cadmium & 0.21 (ND) & 13.9 & Yes \\
\hline Copper & 10.8 & 2,960 & Yes \\
\hline Lead & 5.2 & 353 & Yes \\
\hline \multicolumn{4}{|c|}{ ACL Staging Pile Footprint } \\
\hline Cadmium & 0.21 (ND) & 13.9 & Yes \\
\hline Copper & 369 & 2,960 & Yes \\
\hline Lead & 25.4 & 353 & Yes \\
\hline \multicolumn{4}{|c|}{ Focused Sample } \\
\hline Cadmium & $0.21(\mathrm{ND})$ & 13.9 & Yes \\
\hline Copper & 11.3 & 2,960 & Yes \\
\hline Lead & 63.8 & 353 & Yes \\
\hline
\end{tabular}

${ }^{a}$ Lookup values and RAGs obtained from the Remedial Design Report/Remedial Action Work Plan for the 100 Area (DOE-RL 2005) or calculated per WAC 173-340-720, WAC 173-340-730, and WAC 173-340-740, Method B, 1996, unless otherwise noted.

${ }^{b}$ Criterion is comparison to the cleanup criteria (RAG).

$\mathrm{ACL}=$ above cleanup level

$\mathrm{BCL}=$ below cleanup level

$\mathrm{ND}=$ not detected (in all samples in the data set)

$\mathrm{RAG}=$ remedial action goal

WAC $=$ Washington Administrative Code

5.1.2.2 Noncarcinogenic Hazard Quotient RAG Attained. For noncarcinogenic COCs, WAC 173-340-740(5)(a) and (b) specify the evaluation of the hazard quotient, which is given as the daily intake divided by a reference dose (DOE-RL 2005). This 
evaluation is shown for the ACL staging pile footprint in the $95 \%$ UCL calculation brief (Appendix C). A hazard quotient was not evaluated for the BCL overburden (stockpiled soil) as all nonradionuclide COCs were detected below background. Because lead was the only COC detected above background levels in the shallow zone remediation footprint, no further evaluation of the hazard quotient was required.

The calculated hazard quotient for residual concentrations of copper and lead in the ACL staging pile footprint is $2.0 \times 10^{-1}$. These values are below the individual and cumulative RAGs (a hazard quotient of $<1.0$ in both cases).

5.1.2.3 Carcinogenic Risk RAG Attained. For individual nonradionuclide carcinogenic COCs, the WAC 173-340 Method B cleanup limits are based on an incremental cancer risk of $1 \times 10^{-6}$. For nonradionuclide carcinogenic COCs, the total excess cancer risk must be less than $1 \times 10^{-5}$ (DOE-RL 2005).

Cadmium is the only carcinogenic $\mathrm{COC}$ at this site. Cadmium was not detected in any of the samples collected at the 118-F-7 waste site; therefore, the calculation for carcinogenic risk is not required.

\subsection{GROUNDWATER REMEDIAL ACTION GOALS ATTAINED}

\subsubsection{Radionuclides}

Strontium-90 and cesium-137 were detected in the verification samples for the 118-F-7 shallow zone remediation footprint and ACL staging pile footprint. RESRAD modeling, using distribution coefficient $\left(\mathrm{K}_{\mathrm{d}}\right)$ values of $50 \mathrm{~mL} / \mathrm{g}$ for cesium-137 and $25 \mathrm{~mL} / \mathrm{g}$ for strontium-90, predicts that the soil concentrations of cesium-137 and strontium-90 will be protective of groundwater (and therefore the Columbia River) at the maximum contaminant level that meets the $4 \mathrm{mrem} / \mathrm{yr}$ drinking water standard.

\subsubsection{Nonradionuclides}

Table 7 illustrates the comparison of cleanup verification values to the groundwater protection RAGs. The table shows that residual concentrations of lead in the shallow zone remediation footprint and lead and copper in the ACL staging pile footprint exceeded the soil RAGs for groundwater protection. Given the soil-partitioning coefficient of lead $(30 \mathrm{~mL} / \mathrm{g})$ and copper $(22 \mathrm{~mL} / \mathrm{g})$, the results of the 100 Area Analogous Sites RESRAD Calculations (BHI 2005) indicate that these constituents will not reach groundwater (and therefore the Columbia River) in 1,000 years given a clean zone extending at least $3 \mathrm{~m}(9.8 \mathrm{ft})$. 
Table 7. Attainment of Nonradionuclide Remedial Action Goals for Protection of Groundwater and the Columbia River. (2 Pages)

\begin{tabular}{|c|c|c|c|c|c|}
\hline Nonradionuclides & $\begin{array}{c}\text { Cleanup } \\
\text { Verification } \\
\text { Data Set } \\
(\mathbf{m g} / \mathbf{k g})\end{array}$ & $\begin{array}{l}\text { Soil RAG for } \\
\text { Groundwater } \\
\text { Protection }^{\mathrm{a}} \\
(\mathrm{mg} / \mathrm{kg})\end{array}$ & $\begin{array}{l}\text { Soil RAG for } \\
\text { Columbia River } \\
\text { Protection }^{\mathrm{a}} \\
(\mathrm{mg} / \mathrm{kg})\end{array}$ & $\begin{array}{l}\text { Groundwater } \\
\text { and/or River } \\
\text { Protection } \\
\text { RAGs } \\
\text { Exceeded? }\end{array}$ & $\begin{array}{c}\text { Does RESRAD } \\
\text { Predict } \\
\text { Migration to } \\
\text { Groundwater } \\
\text { in } \\
1,000 \text { Years? }\end{array}$ \\
\hline \multicolumn{6}{|c|}{ Shallow Zone } \\
\hline Cadmium & 0.21 (ND) & $0.81^{b}$ & $0.81^{\mathrm{b}}$ & No & NA \\
\hline Copper & 12.2 & 59.2 & $22.0^{b}$ & No & NA \\
\hline Lead & 10.9 & $10.2^{b}$ & $10.2^{b}$ & Yes & $\mathrm{No}^{\mathrm{C}}$ \\
\hline \multicolumn{6}{|c|}{$B C L$ Overburden } \\
\hline Cadmium & 0.21 (ND) & $0.81^{b}$ & $0.81^{b}$ & No & NA \\
\hline Copper & 10.8 & 59.2 & $22.0^{\mathrm{b}}$ & No & NA \\
\hline Lead & 5.2 & $10.2^{b}$ & $10.2^{b}$ & No & NA \\
\hline \multicolumn{6}{|c|}{ ACL Staging Pile Footprint } \\
\hline Cadmium & 0.21 (ND) & $0.81^{b}$ & $0.81^{b}$ & No & NA \\
\hline Copper & 369 & 59.2 & $22.0^{b}$ & Yes & $\mathrm{No}^{\mathrm{C}}$ \\
\hline Lead & 25.4 & $10.2^{b}$ & $10.2^{b}$ & Yes & $\mathrm{No}^{\mathrm{C}}$ \\
\hline \multicolumn{6}{|c|}{ Focused Sample } \\
\hline Cadmium & 0.21 (ND) & $0.81^{b}$ & $0.81^{b}$ & No & NA \\
\hline Copper & 11.3 & 59.2 & $22.0^{b}$ & No & NA \\
\hline Lead & 63.8 & $10.2^{b}$ & $10.2^{b}$ & Yes & $\mathrm{No}^{\mathrm{C}}$ \\
\hline
\end{tabular}

${ }^{a}$ Lookup values and RAGs obtained from the 100 Area RDR/RAWP (DOE-RL 2005) or calculated per WAC 173-340-720, WAC 173-340-730, and WAC 173-340-740, Method B, 1996, unless otherwise noted.

${ }^{b}$ Where cleanup levels are less than background, cleanup levels default to background (WAC 173-340-700[4][d]) (1996).

c Based on 100 Area Analogous Sites RESRAD Calculations (BHI 2005), with a groundwater table elevation of

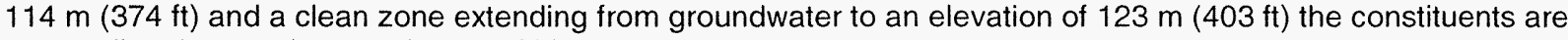
not predicted to reach groundwater within 1,000 years.

$\mathrm{ACL} \quad=$ above cleanup level

$\mathrm{BCL}=$ below cleanup level

NA = Not applicable. RESRAD modeling was not performed because residual concentrations meet the groundwater and river protection RAGs.

ND $\quad=$ not detected (in all samples in the data set)

RAG = remedial action goal

RESRAD = RESidual RADioactivity (dose model)

WAC = Washington Administrative Code 


\subsection{COLUMBIA RIVER REMEDIAL ACTION GOALS ATTAINED}

\subsubsection{Radionuclides}

The river protection RAGs for radionuclides are identical to the groundwater protection RAGs. The results indicated that radionuclides are not predicted to reach groundwater (and, by extension, not predicted to reach the Columbia River) at levels above $4 \mathrm{mrem} / \mathrm{yr}$; therefore, the Columbia River protection RAGs have been attained.

\subsubsection{Nonradionuclides}

Table 7 illustrates the comparison of cleanup verification statistical values to the Columbia River protection RAGs. Residual concentrations of lead in the remediation footprint and lead and copper in the ACL staging pile footprint exceeded the soil RAGs for river protection. Given the soil-partitioning coefficients of lead $(30 \mathrm{~mL} / \mathrm{g})$ and copper $(22 \mathrm{~mL} / \mathrm{g})$, the results of the 100 Area Analogous Sites RESRAD Calculations $(\mathrm{BHI} 2005)$ indicate that these constituents will not reach groundwater (and therefore the Columbia River) in 1,000 years given a clean zone extending at least $3 \mathrm{~m}(9.8 \mathrm{ft})$.

\subsection{WAC 173-340 THREE-PART TEST FOR NONRADIONUCLIDES}

Sections 5.1, 5.2, and 5.3 looked separately at compliance with direct exposure RAGs, groundwater protection soil RAGs, and Columbia River protection soil RAGs.

Section 5.4 documents application of the WAC 173-340 three-part test for nonradionuclides using the most restrictive RAGs applicable to each decision unit (i.e., shallow zone, overburden [stockpiled soil], and ACL staging pile footprint). The most restrictive RAG is defined as the lowest of the direct exposure, groundwater protection, and river protection RAGs. The direct exposure, groundwater protection, and river protection RAGs are applicable to the shallow zone, overburden (stockpiled soil), and ACL staging pile footprint. The WAC 173-340 three-part test consists of the following criteria: (1) the cleanup verification statistical value must be less than the cleanup level, (2) no single detection can exceed two times the cleanup criteria, and (3) the percentage of samples exceeding the cleanup criteria must be less than $10 \%$.

Table 8 summarizes the results of the WAC 173-340 three-part test (WAC 173-340-740[7]) for the shallow zone, overburden (stockpiled soil), and ACL staging pile footprint sample data sets. For cadmium, copper, and lead, the table lists the most restrictive applicable RAG (selected from the RAGs in Table 1), the maximum detected value, the total number of samples collected, and the number of samples exceeding the most restrictive RAG. The final column of the table describes the result of applying the three WAC 173-340 criteria using the values listed in the preceding columns. Table 8 shows that cadmium, copper and lead pass the WAC 173-340 three-part test for all data sets. 
Table 8. Application of the WAC 173-340 Three-Part Test. (2 Pages)

\begin{tabular}{|c|c|c|c|c|c|c|}
\hline Nonradionuclides & $\begin{array}{c}\text { Most } \\
\text { Stringent } \\
\text { Applicable } \\
\text { RAG } \\
(\mathrm{mg} / \mathrm{kg})\end{array}$ & $\begin{array}{c}\text { Statistical } \\
\text { Value } \\
(\mathrm{mg} / \mathrm{kg})^{\mathrm{a}}\end{array}$ & $\begin{array}{c}\text { Maximum } \\
\text { Detected } \\
\text { Value } \\
(\mathrm{mg} / \mathrm{kg})^{\mathrm{b}}\end{array}$ & $\begin{array}{c}\text { Total } \\
\text { Number } \\
\text { of } \\
\text { Samples }^{c}\end{array}$ & $\begin{array}{l}\text { Number } \\
\text { Exceeding } \\
\text { Criteria }^{\mathrm{d}}\end{array}$ & $\begin{array}{c}\text { RAGs } \\
\text { Attained? } \\
\text { (Yes/No) }\end{array}$ \\
\hline \multicolumn{7}{|c|}{ Shallow Zone } \\
\hline Cadmium & $0.81^{e}$ & 0.21 (ND) & 0.21 (ND) & 5 & 0 & Yes \\
\hline Copper & $22.0^{\mathrm{e}}$ & 12.2 & 12.5 & 5 & 0 & Yes \\
\hline Lead & $10.2^{\mathrm{e}}$ & 10.9 & 18.8 & 5 & 1 & Yes $^{\dagger}$ \\
\hline \multicolumn{7}{|c|}{$B C L$ Overburden } \\
\hline Cadmium & $0.81^{e}$ & 0.21 (ND) & 0.21 (ND) & 5 & 0 & Yes \\
\hline Copper & $22.0^{\mathrm{e}}$ & 10.8 & 11.5 & 5 & 0 & Yes \\
\hline Lead & $10.2^{\mathrm{e}}$ & 5.2 & 5.3 & 5 & 0 & Yes \\
\hline \multicolumn{7}{|c|}{ ACL Staging Pile Footprint } \\
\hline Cadmium & $0.81^{\mathrm{e}}$ & 0.21 (ND) & 0.21 (ND) & 5 & 0 & Yes \\
\hline Copper & $22.0^{\mathrm{e}}$ & 369 & 552 & 5 & 1 & Yes $^{g}$ \\
\hline Lead & $10.2^{e}$ & 25.4 & 31.1 & 5 & 1 & Yes $^{f}$ \\
\hline
\end{tabular}

${ }^{a}$ Criterion is comparison to the cleanup criteria (RAG).

${ }^{b}$ Criterion is no single detection can exceed two times the cleanup criteria.

c The total number of samples includes field duplicate samples, which are included in the evaluation as separate samples.

d Criterion is the percentage of samples exceeding the cleanup criteria must be less than $10 \%$.

e Where cleanup levels are less than background or required detection limits (RDLs), cleanup levels default to background or RDLs per WAC 173-340-700(4)(d), and WAC 173-340-707(2), respectively.

f Lead does not meet all three criteria of the WAC 173-340 three part test for the shallow zone and ACL staging pile footprint. However, because lead has a distribution coefficient value of $30 \mathrm{~mL} / \mathrm{g}$, an evaluation based on the 100 Area Analogous Sites RESRAD Calculations (BHI 2005) shows that lead will not reach groundwater (and therefore the Columbia River) within 1,000 years.

${ }^{9}$ Copper does not meet all three criteria of the WAC 173-340 three part test for the ACL staging pile footprint. However, because copper has a distribution coefficient value of $22 \mathrm{~mL} / \mathrm{g}$, an evaluation based on the 100 Area Analogous Sites RESRAD Calculations ( $\mathrm{BHI} 2005$ ) shows that copper will not reach groundwater (and therefore the Columbia River) within 1,000 years.

$\mathrm{ACL}=$ above cleanup level

$\mathrm{BCL}=$ below cleanup level

$\mathrm{ND}=$ not detected (in all samples in the data set)

RAG = remedial action goal

WAC $=$ Washington Administrative Code

\subsection{STATEMENT OF PROTECTIVENESS}

This cleanup verification package demonstrates that remedial action at the 118-F-7 site has achieved the remedial action objectives and corresponding RAGs established in the ROD (EPA 2000) and RDR/RAWP (DOE-RL 2005). The contaminated materials from the site have been excavated and disposed at ERDF. The remaining soils at the 118-F-7 site have been sampled, analyzed, and evaluated. The results of this effort 
indicate that residual concentrations will support future land uses that can be represented (or bounded) by a rural-residential scenario and that residual concentrations throughout the site pose no threat to groundwater or the Columbia River. This site has no deep zone; therefore, no institutional controls are required.

The 118-F-7 site is verified to be remediated in accordance with the ROD (EPA 2000) and may be backfilled.

\subsection{REFERENCES}

40 CFR 141, "National Primary Drinking Water Regulations," Code of Federal Regulations, as amended.

65 FR 76708, "National Primary Drinking Water Regulations; Radionuclides; Final Rule," Federal Register, Vol. 65, No. 236, p. 76708, December 7, 2000.

BHI, 2001, Calculation of Total Uranium Activity Corresponding to a Maximum Contaminant Level for Total Uranium of 30 Micrograms per Liter in Groundwater, 0100X-CA-V0038, Rev. 0, Bechtel Hanford, Inc., Richland, Washington.

BHI, 2004, 100 Area Radionuclide and Nonradionuclide Lookup Values for the 1995 Interim Remedial Action Record of Decision, 0100X-CA-V0046, Rev. 0, Bechtel Hanford, Inc., Richland, Washington.

BHI, 2005, 100 Area Analogous Sites RESRAD Calculations, 0100X-CA-V0050, Rev. 0, Bechtel Hanford, Inc., Richland, Washington.

DOE Order 5400.5, Radiation Protection of the Public and the Environment, U.S. Department of Energy, Washington, D.C.

DOE-RL, 1996, Hanford Site Background: Part 2, Soil Background for Radionuclides, DOERL-96-12, Rev. 0, Richland, U.S. Department of Energy, Richland Operations Office, Richland, Washington.

DOE-RL, 1998, Tri-Party Agreement Handbook Management Procedures, RL-TPA-90-0001, Guideline Number TPA-MP-14, "Maintenance of the Waste Information Data System (WIDS)," U.S. Department of Energy, Richland Operations Office, Richland, Washington.

DOE-RL, 2001, 100 Area Burial Grounds Remedial Action Sampling and Analysis Plan, DOE/RL-2001-35, Rev. 0, U.S. Department of Energy, Richland Operations Office, Richland, Washington.

DOE-RL, 2005, Remedial Design Report/Remedial Action Work Plan for the 100 Area, DOE/RL-96-17, Rev. 5, U.S. Department of Energy, Richland Operations Office, Richland, Washington. 
Ecology, 1994, Natural Background Soil Metals Concentrations in Washington State, Publication No. 94-115, Washington State Department of Ecology, Olympia, Washington.

Ecology, EPA, and DOE, 1989, Hanford Federal Facility Agreement and Consent Order, 2 vols., as amended, Washington State Department of Ecology, U.S. Environmental Protection Agency, and U.S. Department of Energy, Olympia, Washington.

EPA, 1994, Guidance Manual for the Integrated Exposure Uptake Biokinetic Model for Lead in Children, EPA/540/R-93/081, Publication No. 9285.7, U.S.

Environmental Protection Agency, Washington, D.C.

EPA, 2000, Record of Decision for the 100-BC-1, 100-BC-2, 100-DR-1, 100-DR-2, 100-FR-2, 100-HR-2, and 100-KR-2 Operable Units, Hanford Site (100 Area Burial Grounds), Benton County, Washington, U.S. Environmental Protection Agency, Region 10, Seattle, Washington.

WAC 173-340, 1996, "Model Toxics Control Act - Cleanup," Washington Administrative Code.

WCH, 2006, "100-F Field Remediation Cleanup Verification," Meeting Minutes to Distribution from S. W. Callison, CCN 127646, dated May 10, 2006, Washington Closure Hanford, Richland, Washington. 
CVP-2006-00007

Rev. 0 


\section{APPENDIX A}

SUMMARY OF VERIFICATION SOIL SAMPLING RESULTS FOR THE 118-F-7 WASTE SITE CONTAMINANTS OF CONCERN 
CVP-2006-00007

Rev. 0

A-ii 
118-F-7 Shallow Zone Verification Sampling Results.

\begin{tabular}{|c|c|c|c|c|c|c|c|c|c|c|c|c|c|c|}
\hline \multirow{2}{*}{$\begin{array}{c}\text { Sample } \\
\text { Location }\end{array}$} & \multirow{2}{*}{$\begin{array}{c}\text { HEIS } \\
\text { Number }\end{array}$} & \multirow{2}{*}{$\begin{array}{c}\text { Sample } \\
\text { Date }\end{array}$} & \multicolumn{3}{|c|}{ Cesium-137 } & \multicolumn{3}{|c|}{ Cobalt-60 } & \multicolumn{3}{|c|}{ Silver-108m } & \multicolumn{3}{|c|}{ Strontium-90 } \\
\hline & & & $\mathrm{pCi} / \mathrm{g}$ & $\mathbf{Q}$ & MDA & $\mathrm{pCi} / \mathrm{g}$ & $\mathbf{Q}$ & MDA & $\mathrm{pCi} / \mathrm{g}$ & $\mathbf{Q}$ & MDA & $\mathrm{pCi} / \mathrm{g}$ & $Q$ & MDA \\
\hline Al & $J 12 \mathrm{~L} 42$ & $6 / 6 / 06$ & 4.03E-01 & & $1.40 \mathrm{E}-01$ & $2.30 E-01$ & $\mathrm{U}$ & $2.30 \mathrm{E}-01$ & $5.90 E-02$ & $\mathrm{U}$ & $5.90 E-02$ & $2.49 E-01$ & & $2.30 \mathrm{E}-01$ \\
\hline $\mathrm{A} 2$ & $J 12 \mathrm{~L} 43$ & $6 / 6 / 06$ & $1.50 E-01$ & & $1.10 \mathrm{E}-01$ & $1.20 \mathrm{E}-01$ & $\mathrm{U}$ & $1.20 E-01$ & $7.70 E-02$ & $\mathrm{U}$ & 7.70E-02 & 8.00E-03 & $\mathrm{U}$ & 2.20E-01 \\
\hline $\mathrm{A} 3$ & $\mathrm{J12L44}$ & $6 / 6 / 06$ & $1.00 E-01$ & $\mathrm{U}$ & $1.00 \mathrm{E}-01$ & $6.30 E-02$ & $\mathrm{U}$ & $6.30 \mathrm{E}-02$ & $4.80 \mathrm{E}-02$ & $\mathrm{U}$ & $4.80 E-02$ & $7.00 E-02$ & $\mathrm{U}$ & $2.60 \mathrm{E}-01$ \\
\hline $\mathrm{A} 4$ & $\mathrm{~J} 12 \mathrm{~L} 45$ & $6 / 6 / 06$ & $9.80 E-02$ & $\mathrm{U}$ & $9.80 \mathrm{E}-02$ & 1.10E-01 & $\mathrm{U}$ & $1.10 \mathrm{E}-01$ & $5.70 \mathrm{E}-02$ & $\mathrm{U}$ & 5.70E-02 & $5.70 E-02$ & $\mathrm{U}$ & $1.80 E-01$ \\
\hline $\begin{array}{c}\text { Duplicate of } \\
\text { J12L45 }\end{array}$ & $J 12 \mathrm{~L} 46$ & $6 / 6 / 06$ & $1.40 \mathrm{E}-01$ & U & $1.40 E-01$ & 2.00E-01 & $U$ & $2.00 E-01$ & $5.70 \mathrm{E}-02$ & U & 5.70E-02 & $6.50 \mathrm{E}-02$ & U & $2.20 E-01$ \\
\hline $\begin{array}{l}\text { Split of } \\
\text { J12L45 }\end{array}$ & $J 12 L 49$ & $6 / 6 / 06$ & 7.77E-02 & & 2.91E-02 & $1.11 \mathrm{E}-02$ & $U$ & $3.04 E-02$ & 5.77E-03 & $\mathrm{U}$ & 2.29E-02 & $5.05 E-02$ & U & 1.05E-01 \\
\hline $\begin{array}{l}\text { Focused } \\
\text { Sample }\end{array}$ & J12LY7 & $6 / 6 / 06$ & $1.10 E-01$ & U & $1.10 \mathrm{E}-01$ & $1.80 E-01$ & U & $1.80 E-01$ & $5.90 E-02$ & U & 5.90E-02 & $1.68 \mathrm{E}-01$ & U & 2.30E-01 \\
\hline
\end{tabular}

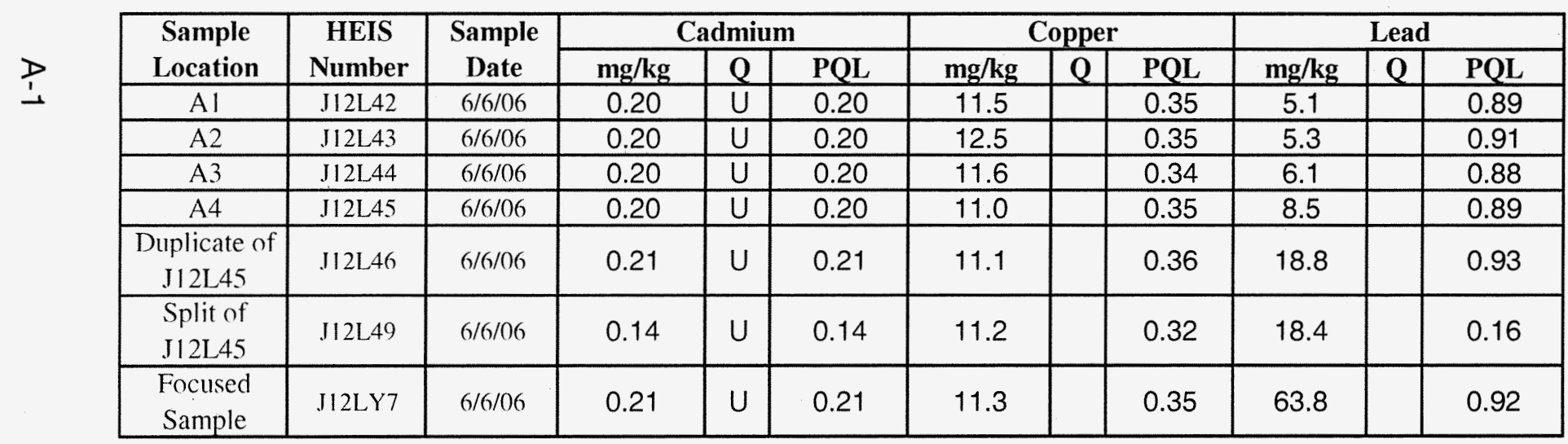

Note: The following abbreviations apply to all Appendix A tables.

Note: Data qualified with $\mathrm{N}$ and $\mathbf{J}$ are considered acceptable values.

$A C L=$ above cleanup levels

$\mathrm{BCL}=$ below cleanup levels

$\mathrm{J}=$ estimated

$\mathrm{MDA}=$ minimum detectable activity

$\mathrm{N}=$ Spiked analyte recovery is outside stated control limits.
$\mathrm{PQL}=$ practical quantitation limit

$\mathrm{Q}=$ qualifier

$\mathrm{U}=$ undetected 
118-F-7 BCL Overburden Verification Sampling Results.

\begin{tabular}{|c|c|c|c|c|c|c|c|c|c|c|c|c|c|c|}
\hline \multirow{2}{*}{$\begin{array}{c}\text { Sample } \\
\text { Location }\end{array}$} & \multirow{2}{*}{$\begin{array}{c}\text { HEIS } \\
\text { Number }\end{array}$} & \multirow{2}{*}{$\begin{array}{c}\text { Sample } \\
\text { Date }\end{array}$} & \multicolumn{3}{|c|}{ Cesium-137 } & \multicolumn{3}{|c|}{ Cobalt-60 } & \multicolumn{3}{|c|}{ Silver-108m } & \multicolumn{3}{|c|}{ Strontium-90 } \\
\hline & & & $\mathrm{pCi} / \mathrm{g}$ & $Q$ & MDA & $\mathrm{pCi} / \mathrm{g}$ & $\mathbf{Q}$ & MDA & $\mathrm{pCi} / \mathrm{g}$ & $\mathbf{Q}$ & MDA & $\mathrm{pCi} / \mathrm{g}$ & $Q$ & MDA \\
\hline $\mathrm{Al}$ & $\mathrm{J} 12 \mathrm{~L} 32$ & $6 / 6 / 06$ & $1.10 \mathrm{E}-01$ & $\vec{U}$ & $.10 E-01$ & $1.90 \mathrm{E}-01$ & $\mathrm{U}$ & $1.90 \mathrm{E}-01$ & $5.70 \mathrm{E}-02$ & $\mathrm{U}$ & $5.70 \mathrm{E}-02$ & $6.00 \mathrm{E}-02$ & $\mathrm{U}$ & $1.60 \mathrm{E}-01$ \\
\hline $\mathrm{A} 2$ & $2 \mathrm{~L} 33$ & & 9.40E-02 & $\mathrm{U}$ & $9.40 \mathrm{E}-02$ & $1.40 \mathrm{E}-01$ & $\mathrm{U}$ & $1.40 \mathrm{E}-01$ & $4.90 \mathrm{E}-02$ & $\mathrm{U}$ & $4.90 \mathrm{E}-02$ & $3.00 \mathrm{E}-03$ & $\mathrm{U}$ & $1.80 \mathrm{E}-01$ \\
\hline $\begin{array}{c}\text { Duplicate of } \\
\text { J12L33 }\end{array}$ & $\mathrm{J} 12 \mathrm{~L} 34$ & $6 / 6 / 06$ & 8.50E-02 & U & 8.50E-02 & 1.00E-01 & U & $1.00 \mathrm{E}-01$ & 5.90E-02 & U & 5.90E-02 & $-7.00 \mathrm{E}-03$ & $\mathrm{U}$ & $1.90 \mathrm{E}-01$ \\
\hline $\mathrm{A} 3$ & $2 \mathrm{~L} 35$ & $0 / 0 / 00$ & 1.20E-01 & $\mathrm{U}$ & $1.20 \mathrm{E}-01$ & $1.80 \mathrm{E}-01$ & $\mathrm{U}$ & $1.80 \mathrm{E}-01$ & $5.40 \mathrm{E}-02$ & $\mathrm{U}$ & $5.40 \mathrm{E}-02$ & $-2.40 \mathrm{E}-02$ & $\mathrm{U}$ & $1.90 \mathrm{E}-01$ \\
\hline $\mathrm{A} 4$ & J12L36 & $6 / 6 / 06$ & $9.90 \mathrm{E}-02$ & $\mathrm{U}$ & $9.90 \mathrm{E}-02$ & $1.60 \mathrm{E}-01$ & $\mathrm{U}$ & $1.60 \mathrm{E}-01$ & $5.40 \mathrm{E}-02$ & $\mathrm{U}$ & $5.40 \mathrm{E}-02$ & $3.20 \mathrm{E}-02$ & $\mathrm{U}$ & 2.00E-01 \\
\hline
\end{tabular}

\begin{tabular}{|c|c|c|c|c|c|c|c|c|c|c|c|}
\hline \multirow{2}{*}{$\begin{array}{c}\text { Sample } \\
\text { Location }\end{array}$} & \multirow{2}{*}{$\begin{array}{c}\text { HEIS } \\
\text { Number }\end{array}$} & \multirow{2}{*}{$\begin{array}{c}\text { Sample } \\
\text { Date }\end{array}$} & \multicolumn{3}{|c|}{ Cadmium } & \multicolumn{3}{|c|}{ Copper } & \multicolumn{3}{|c|}{ Lead } \\
\hline & & & $\mathrm{mg} / \mathrm{kg}$ & $Q$ & PQL & $\mathrm{mg} / \mathrm{kg}$ & $Q$ & $\mathrm{PQL}$ & $\mathrm{mg} / \mathrm{kg}$ & $\mathbf{Q}$ & $\mathrm{PQL}$ \\
\hline $\mathrm{Al}$ & $\mathrm{J} 12 \mathrm{~L} 32$ & $6 / 6 / 06$ & 0.21 & $U$ & 0.21 & 10.4 & & 0.36 & 5.3 & & 0.93 \\
\hline $\mathrm{A} 2$ & J12L33 & $6 / 6 / 06$ & 0.21 & $U$ & 0.21 & 11.5 & & 0.35 & 3.7 & & 0.92 \\
\hline $\begin{array}{c}\text { Duplicate of } \\
\text { J12L33 }\end{array}$ & J12L34 & $6 / 6 / 06$ & 0.21 & $U$ & 0.21 & 10.5 & & 0.35 & 3.8 & & 0.91 \\
\hline $\mathrm{A} 3$ & $\mathrm{~J} 12 \mathrm{~L} 35$ & $6 / 6 / 06$ & 0.20 & $U$ & 0.20 & 10.4 & & 0.35 & 4.8 & & 0.90 \\
\hline $\mathrm{A} 4$ & $\mathrm{~J} 12 \mathrm{~L} 36$ & $6 / 6 / 06$ & 0.21 & $U$ & 0.21 & 10.7 & & 0.35 & 4.4 & & 0.91 \\
\hline $\begin{array}{l}\text { Split of } \\
\text { J12L33 }\end{array}$ & J12L47 & $6 / 6 / 06$ & 0.14 & UN & 0.14 & 12.3 & & 0.32 & 4.0 & & 0.16 \\
\hline
\end{tabular}


118-F-7 ACL Staging Pile Footprint Verification Sampling Results.

\begin{tabular}{|c|c|c|c|c|c|c|c|c|c|c|c|c|c|c|}
\hline \multirow{2}{*}{$\begin{array}{c}\text { Sample } \\
\text { Location }\end{array}$} & \multirow{2}{*}{$\begin{array}{c}\text { HEIS } \\
\text { Number }\end{array}$} & \multirow{2}{*}{$\begin{array}{c}\text { Sample } \\
\text { Date }\end{array}$} & \multicolumn{3}{|c|}{ Cesium-137 } & \multicolumn{3}{|c|}{ Cobalt-60 } & \multicolumn{3}{|c|}{ Silver-108m } & \multicolumn{3}{|c|}{ Strontium-90 } \\
\hline & & & $\mathrm{pCi} / \mathrm{g}$ & $Q$ & MDA & $\mathrm{pCi} / \mathrm{g}$ & $Q$ & MDA & $\mathrm{pCi} / \mathrm{g}$ & $Q$ & MDA & $\mathrm{pCi} / \mathrm{g}$ & $Q$ & MDA \\
\hline $\mathrm{Al}$ & J12L37 & $6 / 6 / 06$ & 1.14E-01 & & $6.60 \mathrm{E}-02$ & $9.60 \mathrm{E}-02$ & $U$ & $9.60 \mathrm{E}-02$ & $5.20 \mathrm{E}-02$ & $\mathrm{U}$ & $5.20 \mathrm{E}-02$ & $8.50 E-02$ & $\mathrm{U}$ & 2.00E-01 \\
\hline $\mathrm{A} 2$ & $.112 \mathrm{~L} 38$ & $6 / 6 / 06$ & $1.30 \mathrm{E}-01$ & $\mathrm{U}$ & $1.30 \mathrm{E}-01$ & $1.50 \mathrm{E}-01$ & $\mathrm{U}$ & $1.50 \mathrm{E}-01$ & $5.80 E-02$ & $\mathrm{U}$ & $5.80 \mathrm{E}-02$ & $8.23 E-01$ & & $2.10 \mathrm{E}-01$ \\
\hline $\mathrm{A} 3$ & $112 \mathrm{~L} 39$ & $6 / 6 / 06$ & $1.91 \mathrm{E}-01$ & & $7.00 \mathrm{E}-02$ & $7.50 \mathrm{E}-02$ & $\mathrm{U}$ & $7.50 \mathrm{E}-02$ & $4.90 E-02$ & $U$ & $4.90 \mathrm{E}-02$ & 1.32E-01 & $\mathrm{U}$ & 2.30E-01 \\
\hline $\begin{array}{c}\text { Duplicate of } \\
\text { J12L40 }\end{array}$ & J12L40 & $6 / 6 / 06$ & $2.25 \mathrm{E}-01$ & & $8.90 E-02$ & $9.50 \mathrm{E}-02$ & U & $9.50 \mathrm{E}-02$ & 5.90E-02 & $U$ & 5.90E-02 & $9.80 E-02$ & U & 2.10E-01 \\
\hline $\mathrm{A} 4$ & $\mathrm{~J} 12 \mathrm{~L} 41$ & $6 / 6 / 06$ & $2.04 \mathrm{E}-01$ & & $9.10 \mathrm{E}-02$ & $1.10 \mathrm{E}-01$ & $\mathrm{U}$ & $1.10 \mathrm{E}-01$ & $6.10 \mathrm{E}-02$ & $\mathrm{U}$ & $6.10 \mathrm{E}-02$ & 5.10E-02 & $\mathrm{U}$ & $2.10 \mathrm{E}-01$ \\
\hline $\begin{array}{l}\text { Split of } \\
\text { J12L40 }\end{array}$ & $\mathrm{J} 12 \mathrm{~L} 48$ & $6 / 6 / 06$ & $1.63 E-01$ & & $2.16 E-02$ & 2.77E-03 & U & $2.51 E-02$ & 2.72E-03 & $U$ & $1.72 \mathrm{E}-02$ & 1.57E-01 & & 1.03E-01 \\
\hline
\end{tabular}

\begin{tabular}{|c|c|c|c|c|c|c|c|c|c|c|c|}
\hline \multirow{2}{*}{$\begin{array}{c}\text { Sample } \\
\text { Location }\end{array}$} & \multirow{2}{*}{$\begin{array}{c}\text { HEIS } \\
\text { Number }\end{array}$} & \multirow{2}{*}{$\begin{array}{c}\text { Sample } \\
\text { Date }\end{array}$} & \multicolumn{3}{|c|}{ Cadmium } & \multicolumn{3}{|c|}{ Copper } & \multicolumn{3}{|c|}{ Lead } \\
\hline & & & $\mathrm{mg} / \mathrm{kg}$ & $\mathrm{Q}$ & PQL & $\mathrm{mg} / \mathrm{kg}$ & $Q$ & PQL & $\mathrm{mg} / \mathrm{kg}$ & $Q$ & PQL \\
\hline $\mathrm{Al}$ & $\mathrm{J12L37}$ & $6 / 6 / 06$ & 0.21 & U & 0.21 & 12.2 & & 0.35 & 17.4 & & 0.92 \\
\hline $\mathrm{A} 2$ & $\mathrm{~J} 12 \mathrm{~L} 38$ & $6 / 6 / 06$ & 0.20 & $\mathrm{U}$ & 0.2 & 11.0 & & 0.35 & 12.2 & & 0.91 \\
\hline A3 & J12L39 & $6 / 6 / 06$ & 0.21 & $\mathrm{U}$ & 0.21 & 11.3 & & 0.36 & 7.4 & & 0.92 \\
\hline $\begin{array}{c}\text { Duplicate of } \\
\text { J12L40 }\end{array}$ & $J 12 \mathrm{~L} 40$ & $6 / 6 / 06$ & 0.21 & U & 0.21 & 10.9 & & 0.35 & 7.6 & & 0.97 \\
\hline A4 & $\mathrm{J} 12 \mathrm{~L} 41$ & $6 / 6 / 06$ & 0.21 & U & 0.21 & 552 & & 0.36 & 31.1 & & 0.93 \\
\hline $\begin{array}{l}\text { Split of } \\
\text { J12L40 }\end{array}$ & $\mathrm{J} 12 \mathrm{~L} 48$ & $6 / 6 / 06$ & 0.14 & UN & 0.14 & 10.4 & & 0.32 & 7.6 & & 0.16 \\
\hline
\end{tabular}


CVP-2006-00007

Rev. 0

A-4 


\section{APPENDIX B}

DATA QUALITY ASSESSMENT

B-i 
CVP-2006-00007

Rev. 0

B-ii 


\section{B1.0 DATA QUALITY ASSESSMENT FOR THE 118-F-7 WASTE SITE}

\section{B1.1 OVERVIEW}

The data quality assessment (DQA) completes the data life cycle (i.e., planning, implementation, and assessment) that was initiated by the data quality objectives process. The DQA includes a review of the field logbook information (WCH 2006d) to verify sample location, date, and time. It also involves a scientific and statistical evaluation of the data to determine if they are of the right type, quality, and quantity to support their intended use for closeout decisions (EPA 2000).

This DQA was performed in accordance with data quality objectives found in the 100 Area Burial Grounds Remedial Action Sampling and Analysis Plan (SAP) (DOE-RL 2001). The DQA is based on the guidelines presented in Guidance for Data Quality Assessment (EPA 2000). Statistical tests used in this DQA were performed as specified in the SAP and the Remedial Design Report/Remedial Action Work Plan for the 100 Area (RDR/RAWP) (DOE-RL 2005). This DQA was performed with respect to the contaminants of concern (COCs) for the 118-F-7 waste site (cesium-137, cobalt-60, silver-108m, strontium, cadmium, copper, and lead) (WCH 2006a).

Prior to performing statistical tests, the field logbook (WCH 2006d), the sample design (WCH 2006b), and sample analytical data are evaluated. A portion of the cleanup verification sample analytical data are validated for compliance requirements (DOE-RL 2001). An evaluation is performed to determine if the laboratory carried out all steps required by the SAP and the laboratory contract governing the conduct of analysis and reporting of the data. Data validation in accordance with validation procedures specified in "Data Validation Procedure for Chemical Analysis" (BHI 2000a) and Data Validation Procedure for Radiochemical Analysis (BHI 2000b) is performed as part of data evaluation. After data evaluation and validation, the appropriate statistical analyses are performed on the adjusted raw analytical data (Appendix $\mathrm{C}$ ) to determine statistical values for each contaminant. The cleanup verification sample analytical data are stored in the Environmental Restoration project-specific database prior to being submitted for inclusion in the Hanford Environmental Information System database and are also summarized in Appendix A.

\section{B1.2 LABORATORY QUALITY MEASURES}

All verification samples are subject to laboratory-specific quality assurance (QA) requirements, including instrument procurement, maintenance, calibration, and operation. Additional laboratory quality control (QC) checks are performed, as appropriate, for the analytical method at a rate of one per sample delivery group (SDG), or 1 in 20, whichever is more frequent. Laboratory internal QC checks include the following: 
- Laboratory Contamination. Each analytical batch contains a laboratory (method) blank (material of similar composition as the samples with known/minimal contamination of the analytes of interest) carried through the complete analytical process. The method blank is used to evaluate samples for false-positive results due to contamination during handling at the laboratory.

- Analytical Accuracy. For most analyses, a known quantity of representative analytes of interest (matrix spike/matrix spike duplicate [MS/MSD]) are added to a separate aliquot of a sample from the analytical batch. The recovery percentage of the added MS is used to evaluate analytical accuracy. For analyses not amenable to MS techniques (e.g., gamma energy analysis) or where analytical recovery is corrected via internal standards (e.g., alpha spectral analyses), accuracy is evaluated from recovery of the QC reference sample (e.g., laboratory control spike or blank spike sample).

- Analytical Precision. Separate aliquots removed from the same sample container (replicate samples) are analyzed for each analytical batch. The replicate sample results (evaluated as relative percent differences [RPDs]) are used to assess analytical precision. However, this method is subject to natural heterogeneities

- QC Reference Samples. A QC reference sample is prepared from an independent standard at a concentration other than that used for calibration, but within the calibration range. Reference samples provide an independent check on analytical technique and methodology.

Laboratories are also subject to periodic and random assessments of the laboratory performance, systems, and overall program. These assessments are performed by the Washington Closure Hanford QA group to ensure that the laboratories are performing within laboratory contract requirements.

\section{B1.3 DATA VALIDATION}

After sampling was completed, all of the fixed-base laboratory data from SDG K0411 were submitted for third-party validation to Level C. Level $\mathrm{C}$ validation procedures are specified in Data Validation Procedure for Radiochemical Analysis (BHI 2000b) and Data Validation Procedure for Chemical Analysis (BHI 2000a).

Level $\mathrm{C}$ validation procedures were used in the review of the following items, as appropriate, for each analytical method:

- Sample holding times

- Method blanks

- MS/MSD recovery

- Surrogate recovery

- Sample replicates (duplicates) 
- Associated batch laboratory control sample results

- Data package completeness

- Achievement of required (or contractual) detection limits (RDLs).

Data flagged by the validator as estimated (i.e., "J") indicate that the associated concentration is an estimate, but that the data may be used for decision-making purposes. Data flagged as below all detection limits (i.e., "U") indicate the contaminant was analyzed for but not detected, and that the concentration is below the minimum detectable activity (MDA) for radionuclides or the practical quantitation limit (PQL) (i.e., reporting limit) for nonradionuclides. For nonradionuclides, nondetects are reported at the PQL. For radionuclides, nondetects report the actual value obtained from analysis (positive or negative but less than the MDA) except for limited analyses where no value can be calculated. In these cases, the MDA is reported. This situation is applicable for sample results that are below detection limits. All other validated results are considered to be accurate within the standard errors associated with the methods.

The adequacy of laboratory QA/QC was evaluated for precision, accuracy, completeness, and RDLs pursuant to the SAP (DOE-RL 2001). The organization performing the data validation reported that, of the data given formal validation, the laboratory met the standards for performance for precision $( \pm 30 \%)$, accuracy $( \pm 30 \%)$, and completeness $(>90 \%)$. Comparison of the RDL with the respective MDA or PQL is discussed in Section B1.4.

SDG K0411 contains 18 samples (J12L32, J12L33, J12L34, J12L35, J12L36, J12L37, J12L38, J12L39, J12L40, J12L41, J12L42, J12L43, J12L44, J12L45, J12L46, J12L48, J12L49, J12LY7). Samples J12L34, J12L40, and J12L46 are field duplicates of samples J12L33, J12L39, and J12L45, respectively. Sample J12LY7 is a focus sample. No equipment blank was collected for this site. SDG K0411 was submitted for thirdparty validation.

- Radionuclides. No major or minor deficiencies were found in the SDG K0411 COC radiological data.

- Nonradionuclides. No major deficiencies were found in the SDG K0411 COC nonradiological data. Minor deficiencies are as follows:

In the field duplicate pair of samples J12L45 and J12L46 there is an elevated RPD for lead of $75 \%$. No qualification is required for elevated RPDs in field duplicate samples. The data are useable for decision-making purposes.

\section{B1.4 LABORATORY DATA EVALUATION}

The following paragraphs include a data evaluation of the remaining verification sample SDGs for the 118-F-7 waste site. Those SDGs are SDGJ 00078, SDG J00080, and 
SDG J00081. SDG J00078 consists of one sample (J12L47), a split of sample J12L33. SDG J00080 consists of one sample (J12L48), which is a split of sample J12L39. SDG J00081 consists of one field sample (J12L49) a split of sample J12L45. The split samples (SDGs J00078, J00080, and J00081) were sent to Severn Trent Laboratories while the bulk of the samples (SDG K0411) were sent to Eberline Analytical Services.

The metals analyses for SDGs J00078, J00080, and J00081 were analyzed at Severn Trent Laboratories' St. Louis, Missouri facility. It is worth noting that not all of the qualifier flags used by the St. Louis laboratory are the same as the standard qualifiers used in the rest of the data set. Because of laboratory reporting conventions forced by shared use of the analytical services contract, some results in SDGs J00078, J00080, and J00081 (samples J12L47, J12L48, and J12L49) were qualified with "N" qualifiers. The "N" qualifier appears in the COC data in Appendix A, qualifying the cadmium results in samples J12L47 and J12L48. The "N" qualifier in this case indicates that there was a problem with the associated MS for cadmium.

The context for assessing the data includes evaluating the sample data using the statistical methodology and parameters specified in the SAP (DOE-RL 2001). This section summarizes the results of the comparison and presents an evaluation of the data.

\section{MAJOR DEFICIENCIES}

Any data anomaly that causes final data to be qualified as rejected ( $R$ flagged) is considered a major deficiency. No major deficiencies were identified in the data.

\section{MINOR DEFICIENCIES}

Sample Holding Times. All of the method-specific holding times were met for all samples in the 118-F-7 data set.

Method Blanks. The method blank is used to evaluate false-positive results in samples due to contamination during handling at the laboratory.

Radionuclides. All of the $\mathrm{COC}$ radionuclide method blank results were within the acceptance criteria.

Nonradionuclides. All of the COC nonradionuclide method blank results were within the acceptance criteria.

MS/MSDs Recoveries. Recovery of spiked analytes in the MS/MSD pair(s) are used to evaluate method efficiency and the effect of the sample matrix on the environmental sample results.

Radionuclides. All MS/MSD recoveries for radionuclide COCs were within acceptance criteria. 
Nonradionuclides. All MS/MSD recoveries for nonradionuclide COCs were within the project-specified acceptance criteria. The MS recovery for cadmium was below the laboratory-specified acceptance criteria at $70 \%$. The laboratory qualified the cadmium data for samples J12L47 and J12L48 with "N" qualifiers to indicate the MS was below their criteria (75\% to $125 \%$ ). The data are within project specified criteria and are useable for decision-making purposes.

RDL Comparison. Reported analytical detection levels for nondetected analytes were compared to the RDLs specified in the RDR/RAWP (DOE-RL 2005). When detected results were obtained, evaluation of detection limits was not performed. The data validation and supplemental data evaluation noted any analyses in which the detection limit (MDA or PQL) was above the SAP RDLs for nondetected analytes.

Radionuclides. All of the reported COC MDAs are sufficiently low for decisionmaking purposes. All values meet the site cleanup criteria as demonstrated in the calculation briefs (Appendix $\mathrm{C}$ ) and discussed in this cleanup verification package.

Nonradionuclides. All of the reported COC MDLs are sufficiently low for decision-making purposes. All values meet the site cleanup criteria as demonstrated in the calculation briefs (Appendix $\mathrm{C}$ ) and discussed in this cleanup verification package.

Precision and Accuracy Evaluation. Analytical accuracy and precision were evaluated by examination of the RPD of the main, duplicate, and split samples (WCH 2006c). Only the COCs detected at five times the target detection limit (or greater) are used for data analysis with respect to accuracy and precision.

Radionuclides. RPDs for the radionuclide analytes were not calculated because an evaluation of the data shows none of the analytes were detected in both the main and duplicate (or split) sample at more than five times the target detection limit.

Nonradionuclides. The RPDs for copper were calculated in the split and duplicate analyses for the shallow zone, overburden (stockpiled soil), and waste staging area footprint. All calculated RPDs for copper were within the range of $0.9 \%$ to $9.1 \%$ and are within the acceptance criterion $(<30 \%)$. The data are useable for decision-making purposes.

RPDs for the remaining COC nonradionuclide analytes were not calculated because an evaluation of the data shows none of the analytes were detected in both the main and duplicate (or split) sample at more than five times the target detection limit. RPDs of analytes detected at low concentrations (less than five times the detection limit) are not considered to be indicative of the analytical system performance. The data are useable for decision-making purposes. 


\section{B1.5 FIELD QUALITY ASSURANCE/QUALITY CONTROL}

Field QA/QC measures were used to assess potential sources of error and cross contamination of soil samples that could bias results. Field QA/QC samples listed in the field logbook (WCH 2006d) are summarized in Table B-1. The main and QA/QC sample results are presented in Appendix A.

Table B-1. Summary of Field Quality Control Samples.

\begin{tabular}{|c|c|c|}
\hline Main Sample & Duplicate & Split \\
\hline $\mathrm{J} 12 \mathrm{~L} 33$ & $\mathrm{~J} 12 \mathrm{~L} 34$ & $\mathrm{~J} 12 \mathrm{~L} 47$ \\
\hline $\mathrm{J} 12 \mathrm{~L} 39$ & $\mathrm{~J} 12 \mathrm{~L} 40$ & $\mathrm{~J} 12 \mathrm{~L} 48$ \\
\hline $\mathrm{J} 12 \mathrm{~L} 45$ & $\mathrm{~J} 12 \mathrm{~L} 46$ & $\mathrm{~J} 12 \mathrm{~L} 49$ \\
\hline
\end{tabular}

Field duplicate samples were collected to provide a relative measure of the degree of local heterogeneity in the sampling medium, unlike laboratory duplicates that are used to evaluate precision in the analytical process. The field duplicates are evaluated by computing the RPD of the duplicate samples for each COC. Only analytes with values above five times the detection limits for both the main and duplicate samples are compared. The $95 \%$ upper confidence limit (UCL) calculation briefs in Appendix C provide details on duplicate pair evaluation and RPD calculation. The data are suitable for the intended purpose of cleanup verification.

Split samples were collected to provide a relative measure of the degree of variability in the sampling, sample handling, and analytical techniques used by commercial laboratories. The field main and split samples are evaluated by computing the RPD of the split samples for each $\mathrm{COC}$ to determine the usability of the verification data. The U.S. Environmental Protection Agency Contract Laboratory Program duplicate sample comparison methodology, USEPA Contract Laboratory Program National Functional Guidelines for Inorganic Data Review (EPA 1994), is used as an initial test of the data from the splits. Only analytes that had values above five times the contractual RDL for both the main and split sample were compared. The 95\% UCL calculation briefs in Appendix $\mathrm{C}$ provide details on split pair RPD calculation. The results are useable for decision-making purposes.

\section{B1.6 SUITABILITY OF DATA}

The DQA for the 118-F-7 waste site determined that the data are of the right type, quality, and quantity to support site cleanup verification decisions within specified error tolerances. The DQA verified that the sample design was sufficient for the purpose of clean site verification. All analytical data were found to be acceptable for decisionmaking purposes. 


\section{B2.0 REFERENCES}

BHI, 2000a, Data Validation Procedure for Chemical Analysis, BHI-01435, Rev. 0, Bechtel Hanford, Inc., Richland, Washington.

BHI, 2000b, Data Validation Procedure for Radiochemical Analysis, BHI-01433, Rev. 0, Bechtel Hanford, Inc., Richland, Washington.

DOE-RL, 2001, 100 Area Burial Grounds Remedial Action Sampling and Analysis Plan, DOE/RL-2001-35, Rev. 0, U.S. Department of Energy, Richland Operations Office, Richland, Washington.

DOE-RL, 2005, Remedial Design Report/Remedial Action Work Plan for the 100 Area, DOE/RL-96-17, Rev. 5, U.S. Department of Energy, Richland Operations Office, Richland, Washington.

EPA, 1994, USEPA Contract Laboratory Program National Functional Guidelines for Inorganic Data Review, EPA 540/R-94/013, U.S. Environmental Protection Agency, Washington, D.C.

EPA, 2000, Guidance for Data Quality Assessment, EPA QA/G-9, QA00 Update, U.S. Environmental Protection Agency, Office of Environmental Information, Washington, D.C.

WCH, 2006a, 100-F Field Remediation Cleanup Verification, CCN 127646, Washington Closure Hanford, Richland, Washington.

WCH, 2006b, 118-F-7 Shallow Zone, ACL, and BCL Overburden Sampling Plan, 0100F-CA-V0267, Rev. 0, Washington Closure Hanford, Richland, Washington.

WCH, 2006c, 118-F-7 Waste Site Cleanup Verification 95\% UCL Calculations, 0100F-CA-V0269, Rev. 0, Washington Closure Hanford, Richland, Washington.

WCH, 2006d, Remedial Sampling, Logbook EFL-1174-1, Washington Closure Hanford, Richland, Washington. 
Rev. 0 
APPENDIX C

\section{CALCULATION BRIEF EXCERPTS}

C-i 


\section{DISCLAIMER FOR CALCULATIONS}

The calculations that are provided in the following appendix have been generated to document compliance with established cleanup levels. These calculations should be used in conjunction with other relevant documents in the Administrative Record.

C-ii 


\section{CALCULATION BRIEFS}

The following calculation briefs have been prepared in accordance with ENG-1, Engineering Services, ENG-1-4.5, "Project Calculations," Washington Closure Hanford, Richland, Washington.

118-F-7 Shallow Zone, ACL, and BCL Overburden Sampling Plan, 0100F-CA-V0267, Rev. 0, Calculation No. 0100F-CA-V0267, Rev. 0, Washington Closure Hanford, Richland, Washington.

118-F-7 Cleanup Verification 95\% UCL Calculations, Calculation No. 0100F-CA-V0269, Rev. 0, Washington Closure Hanford, Richland, Washington.

NOTE: The calculation briefs referenced in this appendix are kept in the active Washington Closure Hanford project files and are available upon request. When the project is completed, the files will be stored in a U.S. Department of Energy, Richland Operations Office repository. Only excerpts of the calculation briefs are included in this appendix. 
CVP-2006-00007

Rev. 0

C-2 


\section{CALCULATION COVER SHEET}

Project Title:

Area

Discipline

Subject

Computer Program
118-F-7 Burial Ground Sample Design

100-F

Environmental Engineering

118-F-7 Shallow Zone, $\mathrm{ACL}$, and $\mathrm{BCL}$

Excel
Job No.

14655

${ }^{*}$ Calc. No. 0100F-CA-V0267

Overburden Sampling Plan

Program No. Excel 2003

The attached calculations have been generated to document compliance with established cleanup levels. These

calculations should be used in conjuction with other relevent documents in the administrative record.

Committed Calculation $\square \quad$ Preliminary $\square \quad$ Superseded $\square \quad$ voided $\square$

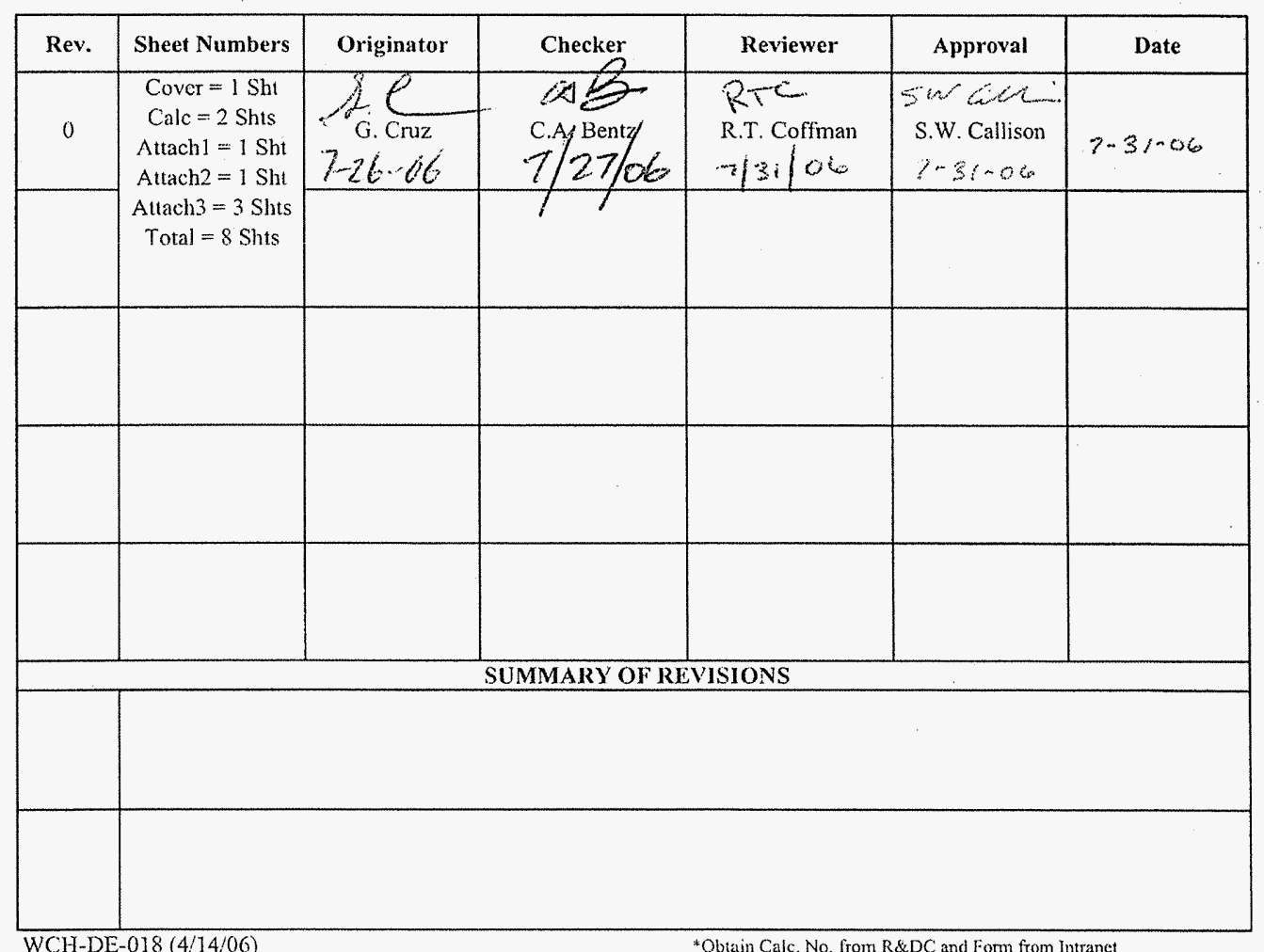


Washington Closure Hanford

Project 118-F-7 Burial Ground Sample Design Subject

\section{CALCULATION SHEET}

Calc. No. 0100F-CA-V0267 Rev. No. 0 Job No. $\frac{14655 \text { Checked } \frac{\text { cDS }}{\text { Sheet No. 1of2 }} 7 / 27 / 06}{\text { Date }}$

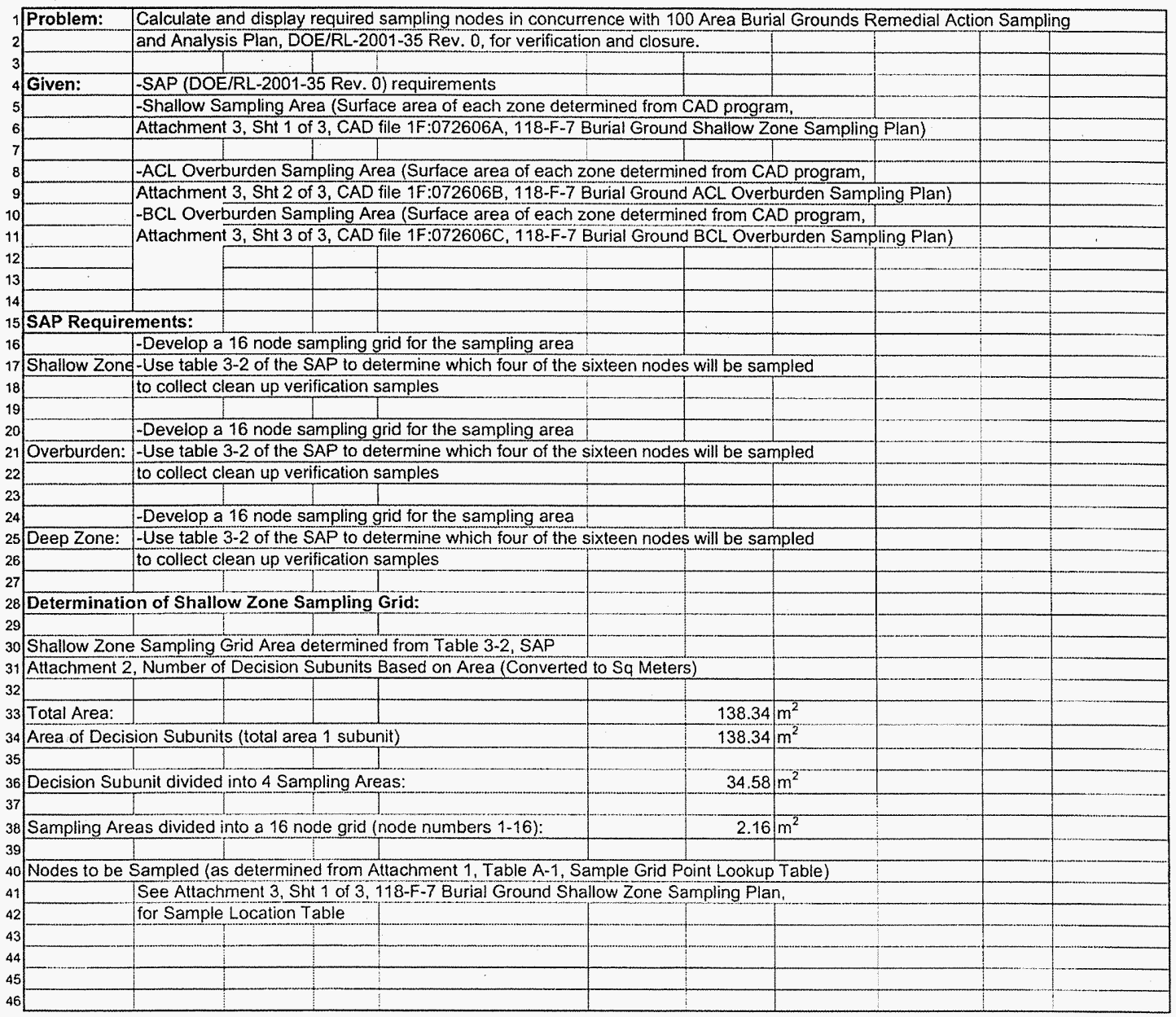




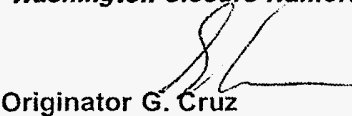

Date $7 / 26 / 2006$

Calc. No. 0100F-CA-V0267 Rev. No. 0

Project 118-F-7 Burial Ground Sample Design Job No. 14655 Checked $\& \&$ Date $7 / 27 / 06$

Subject 118-F-7 Shallow Zone, ACL, and BCL Overburden Sampling Plan Sheet No. 2of2

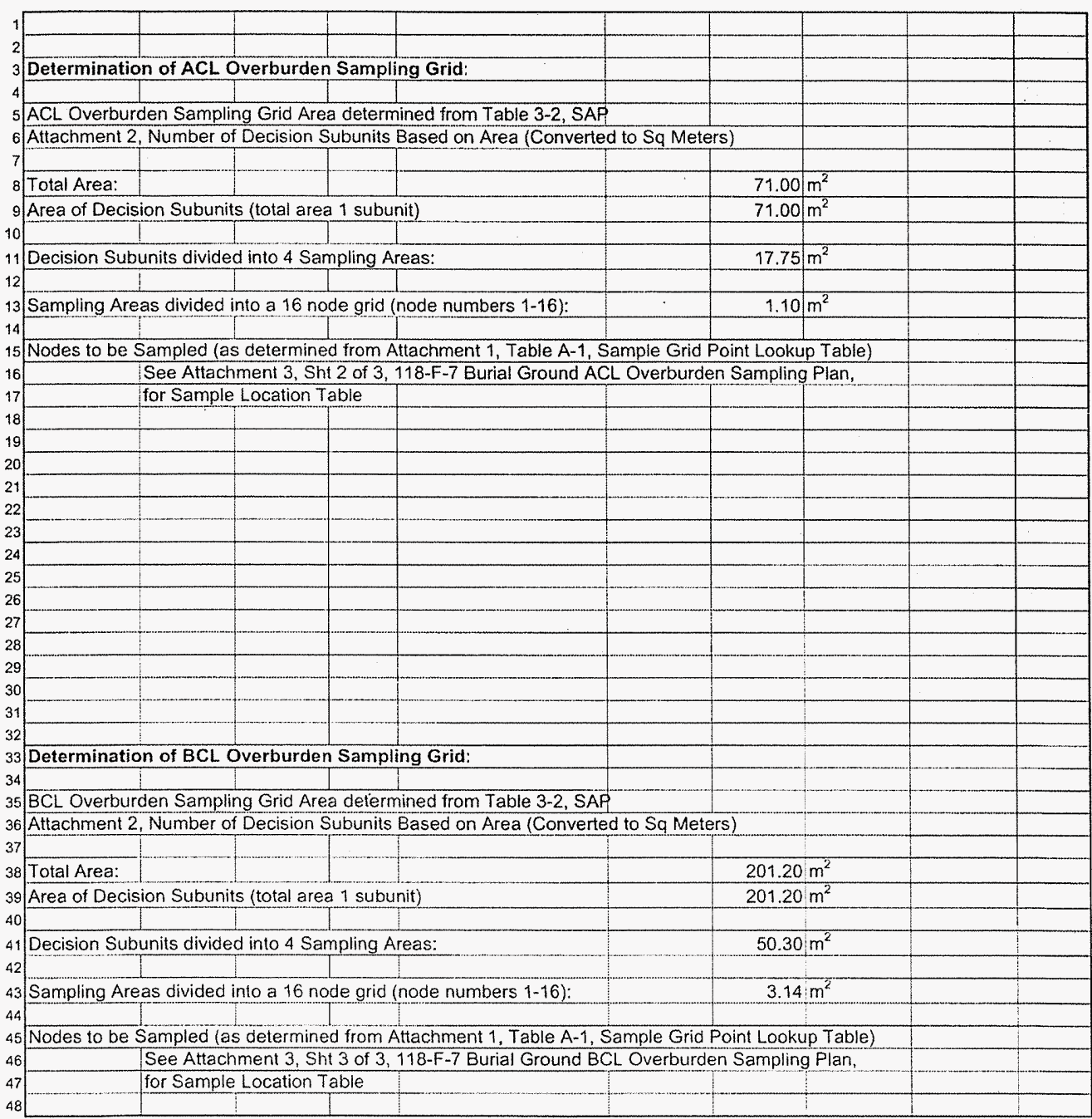




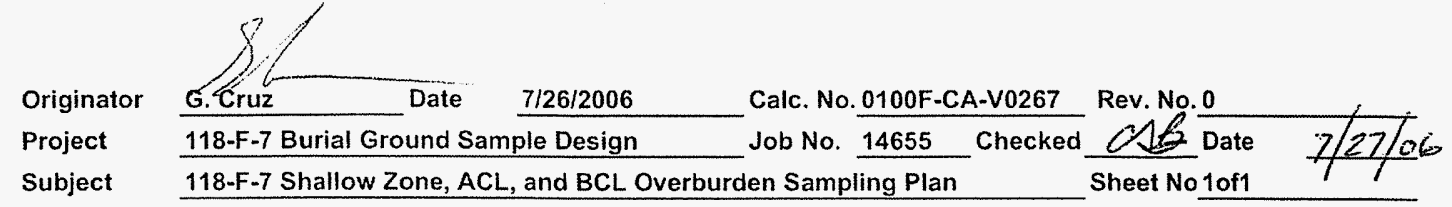

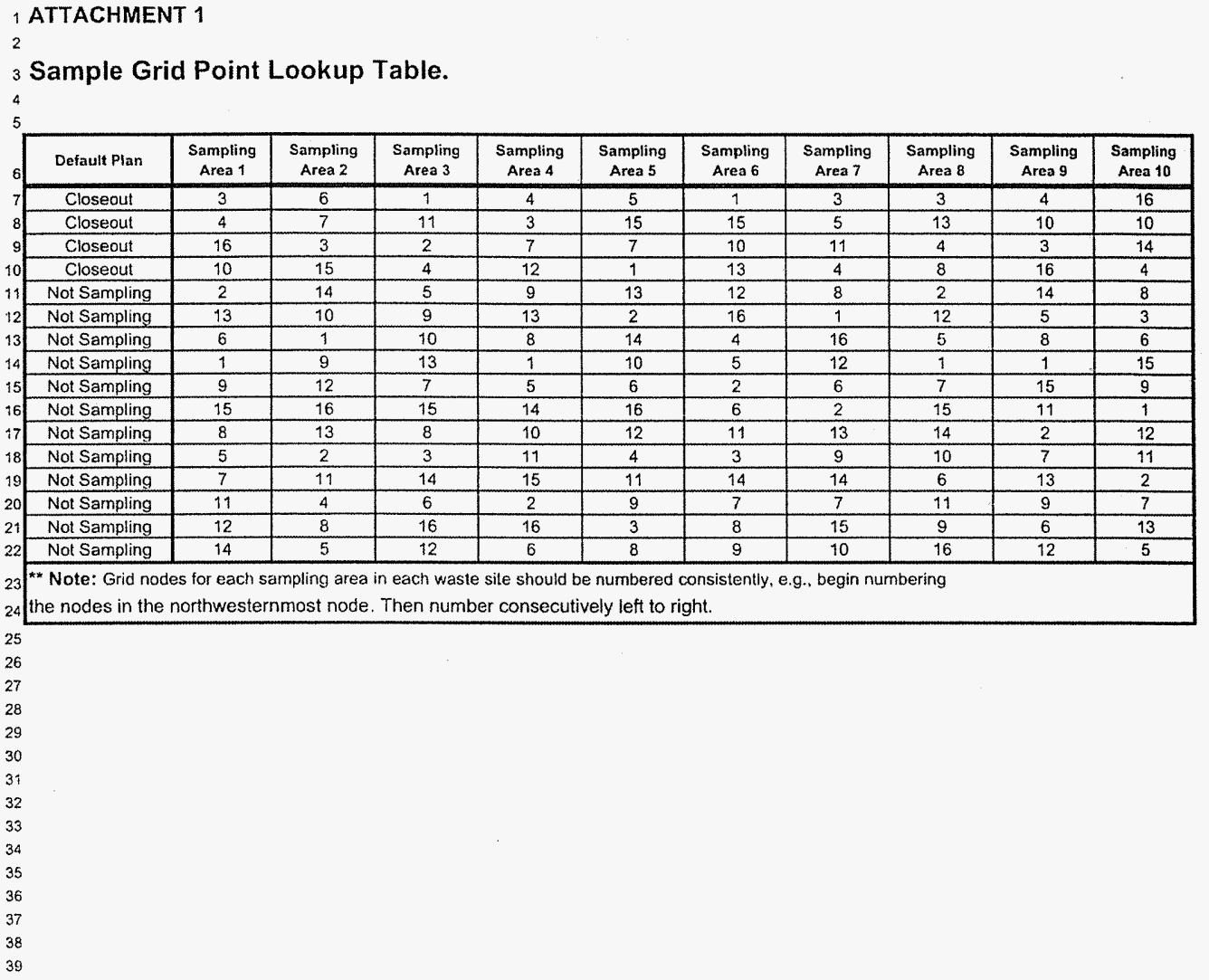


CVP-2006-00007

Rev. 0

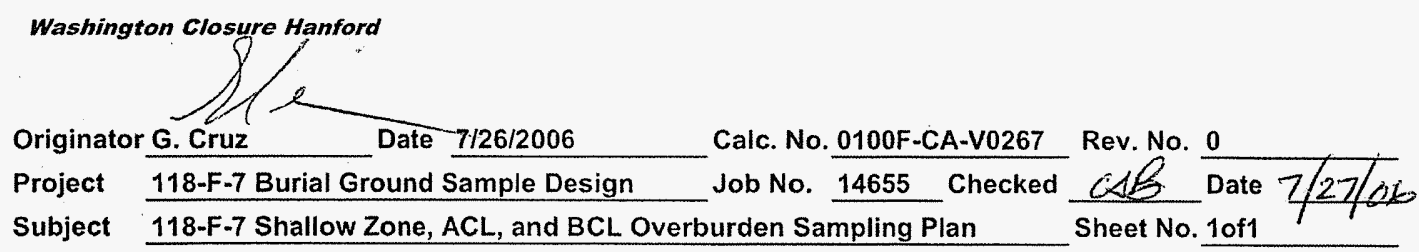

\begin{tabular}{|c|c|c|c|c|c|c|}
\hline \multicolumn{7}{|c|}{${ }_{3}$ Number of Decision Subunits Based on Area. } \\
\hline 8 & \multicolumn{6}{|c|}{ Site Verification Sampling Frequencies Based on Area. } \\
\hline 10 & Decision Unit ${ }^{2}$ & Waste Site Size" & $\begin{array}{l}\text { Decision } \\
\text { Subunits }\end{array}$ & Blocks $^{\mathrm{c}}$ & $\begin{array}{l}\text { Discrete } \\
\text { Samples }\end{array}$ & $\begin{array}{l}\text { Composite } \\
\text { Samples }\end{array}$ \\
\hline 12 & \multirow{3}{*}{$\begin{array}{l}\text { Shallow zonc - } \\
01015 \mathrm{ft}\end{array}$} & Snall: $<100,000 \mathrm{fi}^{2}$ & 1 & 4 & 16 & 4 \\
\hline 13 & & Medium: $>100,000 \mathrm{ft}^{2}<400,000 \mathrm{ft}^{2}$ & 4 & 16 & 64 & 16 \\
\hline 14 & & Large: $>400,000 \mathrm{ft}^{2}$ & 8 & 32 & 128 & 32 \\
\hline 15 & \multirow{3}{*}{$\begin{array}{l}\text { Deep Zone - } \\
>15 \mathrm{ft}\end{array}$} & Small: $<100,000 \mathrm{ft}^{2}$ & 1 & 4 & 16 & 4 \\
\hline 10 & & Medium: $>100,000 \mathrm{ft}^{2}<400,000 \mathrm{ft}^{2}$ & 4 & 16 & 64 & 16 \\
\hline 17 & & Large: $>400.000 \mathrm{ft}^{2}$ & 8 & 32 & 128 & 32 \\
\hline 18 & \multirow{3}{*}{$\begin{array}{l}\text { Overburen/layback } \\
\text { stockpiles }\end{array}$} & Small: $<100,000 \mathrm{ft}^{2}$ & 1 & 4 & 16 & 4 \\
\hline 19 & & Medium: $>100,000 \mathrm{ft}^{2}<400,000 \mathrm{ft}^{2}$ & 4 & 16 & 64 & 16 \\
\hline 19 & & Large: $>400.000 \mathrm{f}^{2}$ & 8 & 32 & 128 & 32 \\
\hline 20 & \multirow{3}{*}{$\begin{array}{l}\text { Staging pile areas } \\
\text { (residual soil) }\end{array}$} & Small: $<100,000 \mathrm{ft}^{2}$ & 1 & 4 & 16 & 4 \\
\hline 21 & & Medium: $>100,000 \mathrm{ft}^{2}<400,000 \mathrm{ft}^{2}$ & 4 & 16 & 64 & 16 \\
\hline 22 & & Large: $>400,000 \mathrm{ft}^{2}$ & 8 & 32 & 128 & 32 \\
\hline
\end{tabular}

- The shallow zone, deep zonc, overburden stockpile, and staging pile areus each represent single decision units. The total number of decision - units will vary because individual waste sites may not have a decp zonc, overburden stockpilc, and/or staging pile areas.

Area of exposed surface after excavalion or area of stockpie base (as applicabic)

'Decision subunits are divided imo four blocks to cnsure that random sampling locations are not bunched together in one are 


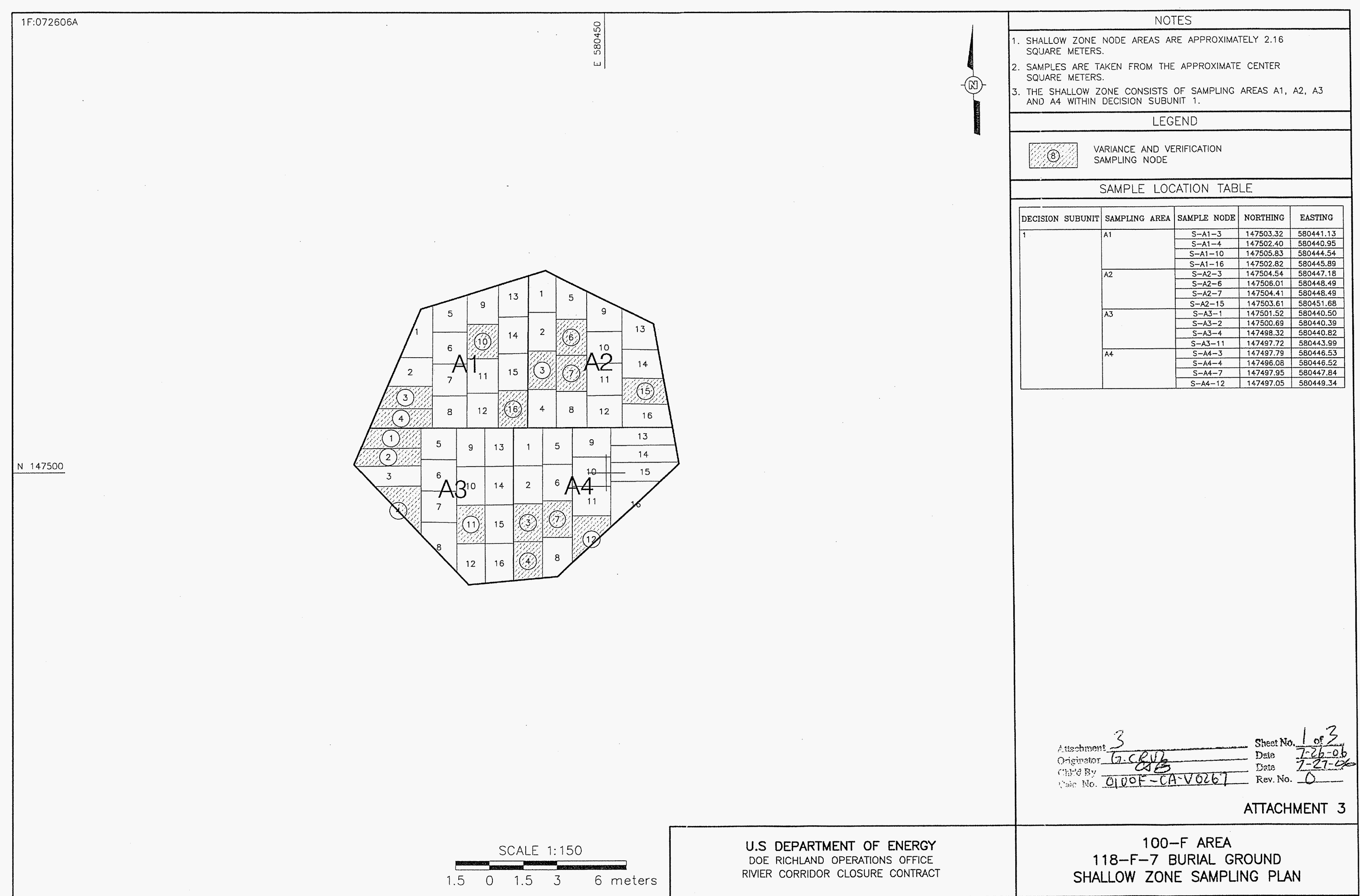




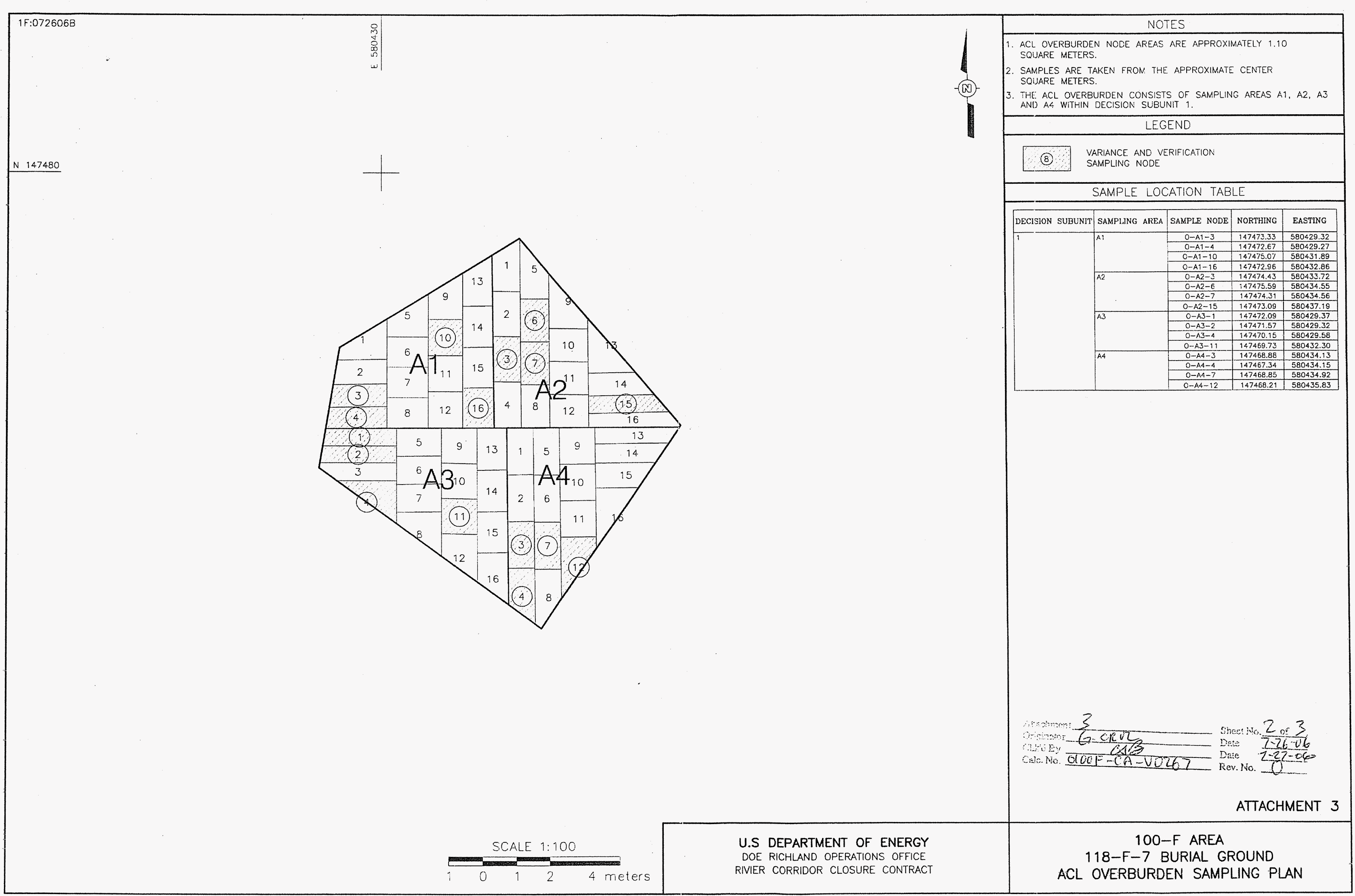




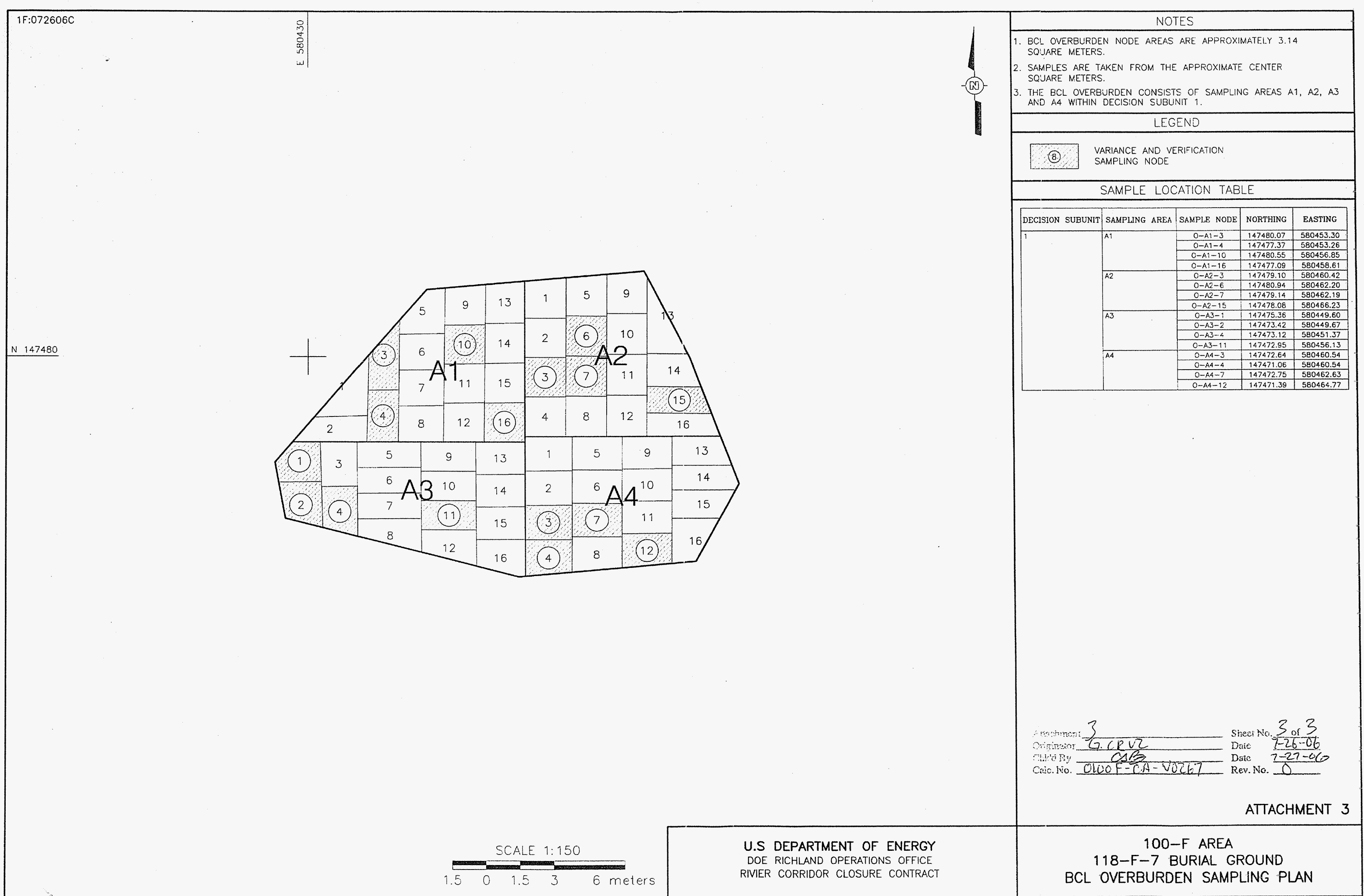




\section{CALCULATION COVER SHEET}

Project Title:

Area

Discipllne

Subject

Computer Program
100-F Area Field Remediation

$100 \cdot \mathrm{F}$

Environmental

${ }^{\star}$ Calc.

$\frac{\text { Excel }}{\text { Program No. }}$
Job No. $0100 \mathrm{~F}-\mathrm{CA}-\mathrm{V} 0260$

Excel 2003

The attached calculations have been generated to document compliance with established cleanup levels. These calculations should be used in conjunction wilh other relevant documents in the administrative record.

\section{Committed Calculation $\square \quad$ Preliminary $\square \quad$ Superseded $\square \quad$ Volded $\square$}

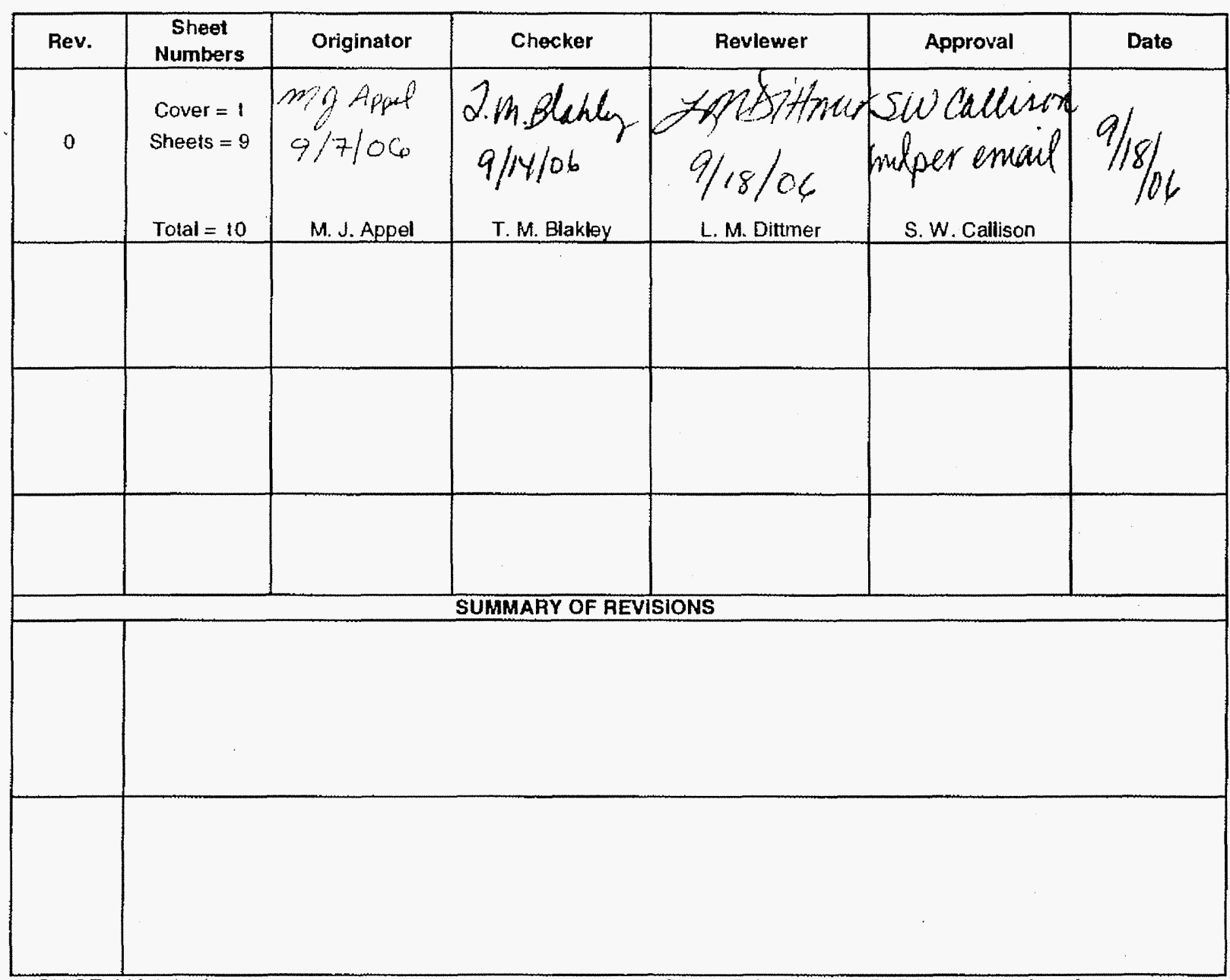


Originator M. J. Appel DOP Propect 100-F Anga Field Ad hediation subject $118-F \cdot 7$ Cleanup Verification $95 \%$ UCL Calculation

\section{CALCULATION SHEET}

Date 09/07/06 ob No. 14655

Ca1c. No. OtDOF-CA-VOzag Chocked T.M. Blakley. $\mathrm{n} 3$
Rev. No. $\frac{0}{\text { Date }}-\frac{9114 / 06}{1 \text { ot } 9}$
Sheet No.

\section{Summary}

1 Purpose:

3 Calculate the $95 \%$ upper confidence limit (UCL) to evaluate compliance with cleanup stenderds tor the subject site. Also, calculate the carcinogenic 4 risk tor applicable nonradionuclida analytes, perform the Washington Administrative Code (WAC) 173-340 (Madel Toxics Control Act [MTCA]) 3-part 5 test, It required, and calculate the ralative percent difference (RPD) tor each contaminant of concem (COC).

6

7 Tabie of Contents:

9 Sheots 1 to 2 - Calculation Sheet Summary

to Sheet 3 - Calculation Sheet Shallow Zone Verification

11 Sheet 4 - Calculation Sheet Overtiunden Veritlcation

12 Sheet 5 - Calculation Sheet Waste Staging Area Veritication

14 Sheets 6 to 8 - Calculation Sheet Split-Duplicate Analysis

Given/Reforences:

7 t) Sample Fesults (Attachment t).

9 2) Background values and remedlal action goals (RAGs) are taken trom DOE-AL (2005b), DOE-RL (200 t), and Ecology (2005)

3) DOE-AL, 200t, Hantord Site Background: Part 1, Soil Background for Nonradioactlve Analytes, DOE/RL-92-24, Rev, 4,

U.S. Department of Energy, Fichlend Operations Ottice. Fichland, Washington.

4) DOE-PL, 2001, 100 Area Burial Grounds Remedial Action Sempling and Analysis Plan, DOE/AL 2001-35, Rev. 0, U.S. Department ol Energy, Fichland Operations Ottice, Fichland, Washington.

5) DOE-RL, 2005b, Remedial Destgn Report/Remedlal Action Work Plan tor the 100 Area (RDR/RAWP), DOE/RL-96-17, Rev. 5, U.S. Department of Eneryy, Richland Operations Office, Richlend, Washington.

6) Ecology, 1992, Statistical Guidance tor Ecology Sile Managers, Publication \$92-54, Washinglon Department of Ecology, Olympia, Washington.

31 7) Ecology, 1993, Statistical Guidence tor Ecology Site Managers, Supplement S-6, Analyzing Site or Background Data with Belowndetection Ulmit or Below-POL Values (Censored Data Sets), Publication \#92-54. Washington Department of Ecology, Olympla, Washington

8) Ecology. 2005. Cleanup Levels and Fisk Calculations (CLARC) Dalahase, Washington State Department of Ecology. Olympia, Washington, <https:i/lortress, wa.gov/ecy/clarc/CLARCHome.aspx>

9) EPA, 1994, USEPA Contract Laboratory Proyram National Functional Guidelines tor trorganic Date Feview,

EPA 540/F-94/013. U.S. Environmental Protection Agency, Washington, D.C.

10) WAC 173-340, 1996, "Model Toxic Control ACt - Cleanup," Washington Administrative Code.

Solution:

Calculation methodology is described in Ecology Pub. \#92-54 (Ecology 1992, 1993), below, and in the RDR/RAWP (DOE-RL 2005b). Use dala trom 44 the attached worksheets to calculate the $95 \%$ UCL, hazard quotients, excess carcinogenic risk, perform the WAC $173-3403-\rho 8$ t test tor 46 nonradionuclides, and catculate the RPD tor each $C O C$ in the primary-dupllcate and primary-split sample pairs.

The subject calculations wera pertormed on data trom soil veritication semples trom the $118-\mathrm{F}-7$ waste site. The data were entered into en EXCEt 502003 spraadsheet and caiculations pertormed by utllizing the buitt-in spreadsheet tunctlons andior craating tormulse within the cells. The statistica 52 evaluation of data tor use in accordanco with the RDRAAWP (DOE-AL 2005D) is documented by this calculetion. Split and duplicate RPD results 53 are used in evaluation of data quality and are presented in the cleanup ventication package (CVP) tor this site.

57 For nonradioactive analytes with $<50 \%$ of the data below delection llmits and all redlonuclide analyes, the statistical value catculated to evaluate the 58 effectiveness of cleanup is the $95 \% \mathrm{UCL}$. For nonedioative an

59 set is used instead of the $95 \%$ UCL. All nonradionuclice data reported as being below detection fimits are set to $/ 4$ the detection limit value tor

60 Calculation of the statistics (Ecology 1993). For redionuclide data, calculation of the statistics wes done on the reported value. In cases where the 62 laboratory does not roport a value below the minimel detectable ectivity (MDA), halt of the MDA is used in the calculation. For the statistical 63 evaluation of primary-dupllcate sample pairs, the samples are averaged betore being included in the data set, after adjus tments tor censored data as 64 described above.

65

67 The COCs tor the 1 t8-F-7 Burial Ground are: Cedmium, Laad, Cobalt-60, Cesium-137, Silver-108m. and Strontlum-90. Based on the metal analysis 68 results, copper was added as a contaminant of concem because of a sirgle delection thet exceeded groundweter and niver water protection in the 69 above cleanup level (ACL) waste slaging tootonnt. All other sampling resulls tor the non-COC metal analyses (shallow zone, overturden, and the 70 waste staging pile area) were below beckground and, theretore, not evaluated.

72

73 For nonradtonuctidas. the WAC $173-340$ statistical guidance suggests that a test tor distributional tom be performed on the deta and the $95 \%$ UC 74 calculated on the appropriate distribution using Ecology soltware. For nonradionuclide small data sets $(n<10)$ and all radionuclide deta sets. the 75 calculatlons are pertormed assuming nonparametric distribution, so no lest tor distribution is performed. For nonradionuclide data sets ot ten or 76 greater, distributional testing is done Lising Ecology's MTCAStat sotware (Ecolngy t993). Background values are subtracted tor epplicable 78 radtonuclides only. Companison against background levels tor nonradionuclldes is included within the CVP. 


\section{Washington Closure Hanford}

Origlnator M. J. Appel $27 / 9,2$

Profect 100 -F Area Fleld Fémedialion

Sublect $t$ t8-F.7 Cleanup Venfication $95 \%$ UCL Calculation

\section{CALCULATION SHEET}

Date 09/07/06

ob No. 14655
Calc. No. 0100F-CA-V0269

Checked T.M. Blekley rara
Rev. No.

Date $9114 / 06$

\section{Summary (continued)}

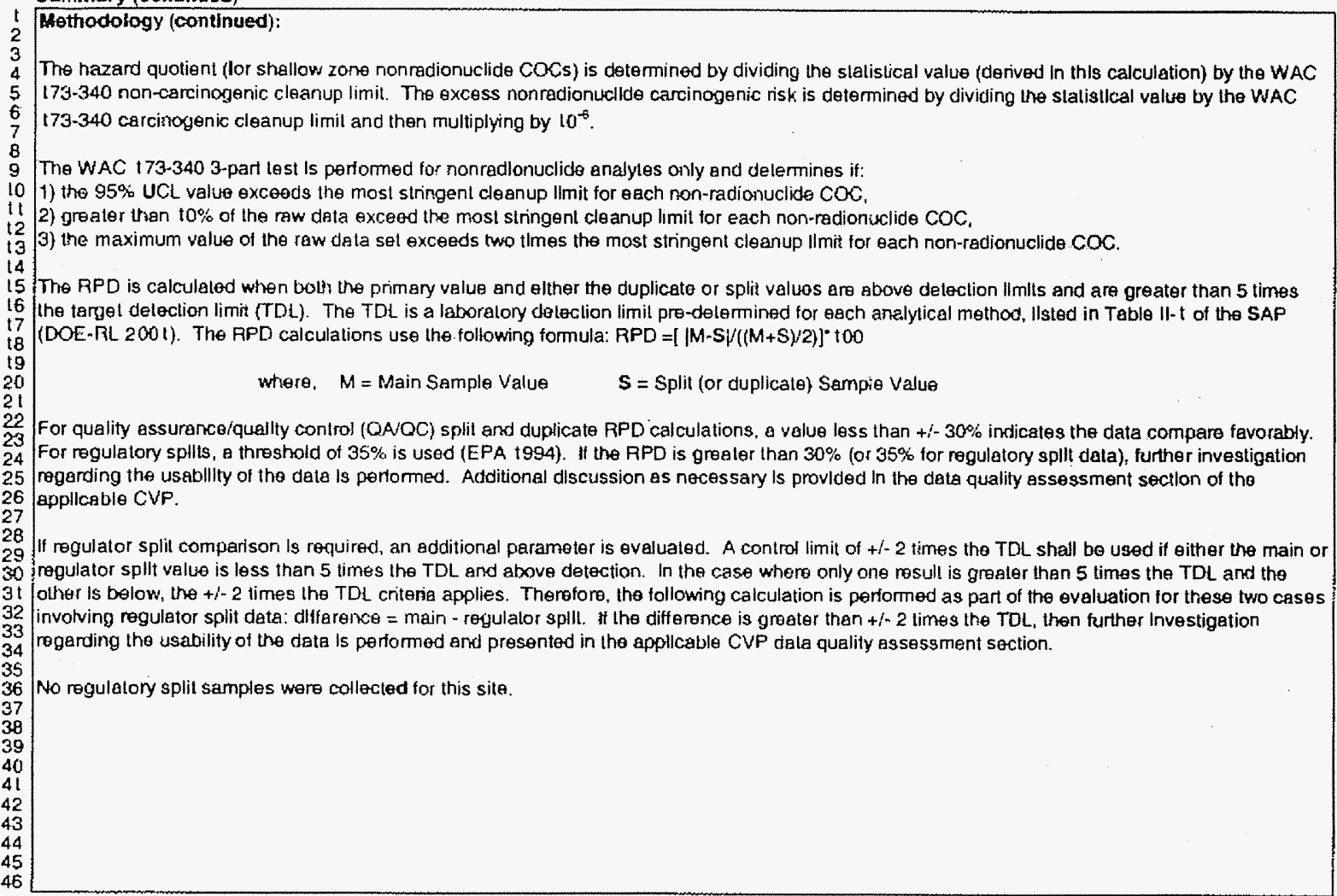


Washington Ciosure Hanford

Ortginator M. J. Appel $T 2 / 1$ Project 100 -F Area Fistd Fómediation

Subject $\frac{100-F \text { Area Fifld Pemediation }}{118-\mathrm{F}-7 \text { Cleanup Verification } 95 \% \text { UCL Calculations }}$

\section{CALCULATION SHEET}

Date 09/07/06
Calc. No. 0100F-CA-V0269 Checked T. M. Blakley in 3

Summary (contlnued)

1 Results:

2 The results presented in the summary tables that follow are for use in the 118-F-7 CVP

\begin{tabular}{|c|c|c|c|c|c|c|c|}
\hline \multicolumn{8}{|c|}{ Results Summary } \\
\hline \multirow{2}{*}{ Analyte } & \multicolumn{2}{|c|}{ Shallow Zone } & \multicolumn{2}{|c|}{ Overburden } & \multicolumn{2}{|c|}{ Waste Stagling Area } & \multirow{2}{*}{ Units } \\
\hline & Result & Quallifer & Result & Quallfier & Result & Qualtiler & \\
\hline Cadmium & $2.1 \mathrm{E}-01$ & U & 2.1E.01 & $\mathrm{U}$ & $2,1 E-01$ & $U$ & $\mathrm{mg} / \mathrm{kg}$ \\
\hline Copper ${ }^{3}$ & $1.22 E+01$ & & $1.08 E+01$ & & $3.69 E+02$ & & $\mathrm{mg} / \mathrm{kg}$ \\
\hline Lead & $1.09 E+01$ & & $5.2 E+00$ & & $2.54 \mathrm{E}+01$ & & $\mathrm{mg} / \mathrm{kg}$ \\
\hline Cobalt- 60 & $2.30 E-01$ & $\mathrm{U}$ & $1.82 \mathrm{E}-01$ & $U$ & $1.50 \mathrm{E}-01$ & $\mathrm{U}$ & $\mathrm{pCi} / \mathrm{g}$ \\
\hline Cesium-137 & $3.01 E-01$ & & $O(<B G)$ & $\mathrm{U}$ & $2.05 E-01$ & & pcivg \\
\hline Silver $-108 \mathrm{~m}$ & $3.51 E-02$ & U & $2.81 E-02$ & $\mathrm{U}$ & $2.98 E-02$ & $\mathrm{U}$ & $\mathrm{pCl} / \mathrm{g}$ \\
\hline Strontium- 90 & $1.83 \mathrm{E}-01$ & & $0(<B G)$ & $\mathrm{U}$ & $5.73 \mathrm{E}-01$ & & pClig \\
\hline
\end{tabular}

3 Strontium-90

$1.83 \mathrm{E}-01$ ।

$5.73 \mathrm{E}-01$ pClig

4 - Included as a COPC tor the Waste Staging Area due to a single detection that exceeded groundwater and river prolection lookup values.

$15 \mathrm{NA}=$ not Eapplicable

$16 \mathrm{U}=$ undetecled

18 WAC 173-340 Evaluation (Shallow Zone)

19

20 3-Part Test:

$2195 \%$ UCL $>$ Cleanup Limil?

$22>10 \%$ above Cleanup Limlt? YES

23 Any sample $>2 \times$ Cleanup Limit? NO

24

25 Because of the "yes" answers to the MTCA 3-part test

26 additional stte-specific evaluation will be pertormed for lead

27 within the CVP

29 Risk Estimate:

30 Nonrad noncarcinogenic index sum: $3.1 E-02$

31 Nonrad carcinogenic risk: 0

32

33 WAC 173-340 Evaluation (Waste Staging Area)

34

35 3-Part Tost:

36 95\% UCL > Cleanup Limir? YES

$37>10 \%$ above Cleanup LImit? YES

38 Any sample $>2 \times$ Cleanup Limit? YES

39

40 Because of the "yes" answers to the MTCA 3-part 1est

41 additional site-specific evaluation will be performed for lead

42 within the CVP.

43

44 Risk Estimate:

45 Nonrad noncarclnogentc index sum: $2.0 E-01$

46 Nonrad carcinogenic risk: 0

47

48

49 Relative Percent Difference Results* QANOC Analysis

\begin{tabular}{|c|c|c|c|c|c|c|c|}
\hline \multirow[t]{2}{*}{50} & \multirow[b]{2}{*}{ Analyte } & \multicolumn{2}{|c|}{ Shallow Zone } & \multicolumn{2}{|c|}{ Overburden } & \multicolumn{2}{|c|}{ Waste Staglng Area } \\
\hline & & $\begin{array}{l}\text { Duplicate } \\
\text { Analysis"* }\end{array}$ & $\begin{array}{c}\text { Split } \\
\text { Analysis"” }\end{array}$ & $\begin{array}{l}\text { Duplicate } \\
\text { Analysis** }\end{array}$ & $\begin{array}{c}\text { Spilt } \\
\text { Analysis"* }\end{array}$ & $\begin{array}{l}\text { Dupllcate } \\
\text { Analysis" }\end{array}$ & $\begin{array}{c}\text { Splih } \\
\text { Analysis }\end{array}$ \\
\hline 2 & Cadmium & & & & & & \\
\hline 53 & Copper" & $0.9 \%$ & $1.8 \%$ & $9.1 \%$ & $6.7 \%$ & $3.6 \%$ & $8.3 \%$ \\
\hline 54 & Lead & & & & & & \\
\hline 55 & Cobait 60 & & & & & & \\
\hline 56 & Cersium-137 & & & & & & \\
\hline 57 & Silver- $108 \mathrm{~m}$ & & & & & & \\
\hline 58 & Strontium-90 & & & & & & \\
\hline
\end{tabular}

59 "A blank cell indicales that APD evaluation was rot requlred

60 " The significance of the reported RPD values, including valwes greater than $3 \% \%$, is addressed within the Dala Quality Assessment section of the CVP tor this site. 61 "included as a COPC tor the Wasle Staging Area due to a single detection that exceeded grounowater and river protection kookup values

$62 \mathrm{NA}=$ not applicable

63 QAVC - qualify assurancelquality control $\quad U=$ undelected

WAC 173-340 Evaluation (Overburden)

\section{3-Part Tes:}

$95 \%$ UCL $>$ Cleanup Limlt?

$>10 \%$ above Cleanup Limll?

NO

Any sample $>2 \times$ Cleanup Limit? NO

Risk Estimate:

Nonrad noncarcinogenlc index sum: 0

Nonrad carcinogenic risk: $0 \quad 0$ 
Washington Closure Hanford

Originator M. J. Appel $M T / 2$

Subject $118-\mathrm{F}-7$ Cleanup Verification 95\% UCL Calculations

Date $97 / 106$
Job No. 14655 $\quad \begin{aligned} & \text { Calc. No. } \frac{0100 F-C A-V 0269}{\text { Checked }} \\ & \text { T. M. Blakley 23m }\end{aligned}$

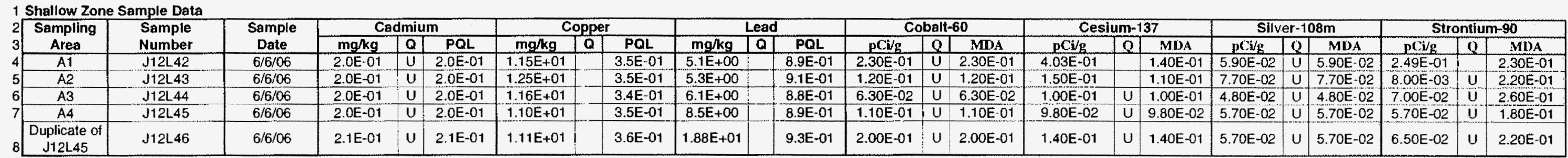

11 Statistical Computation Input Data

\begin{tabular}{|c|c|c|c|c|c|c|c|}
\hline $\begin{array}{c}12 \\
13 \\
13\end{array}$ & $\begin{array}{l}\text { Sample } \\
\text { Number }\end{array}$ & $\begin{array}{c}\text { Sample } \\
\text { Date }\end{array}$ & $\begin{array}{c}\text { Cadmium } \\
\text { mgkg }\end{array}$ & $\begin{array}{c}\text { Copper } \\
\mathrm{mg} / \mathrm{kg}\end{array}$ & $\begin{array}{c}\text { Lead } \\
\text { mg/k }\end{array}$ & $\begin{array}{c}\text { Cobalt-60 } \\
\mathrm{pC} / \mathrm{j} g\end{array}$ & $\begin{array}{c}\text { Ceslum-137 } \\
\mathrm{pC}^{2} / \mathrm{g}\end{array}$ \\
\hline & $J 12 L 42$ & & $1.0 \mathrm{E}-01$ & $1.15 \mathrm{E}+01$ & $5.1 \mathrm{E}+00$ & $1.15 E-01$ & $4.03 E-01$ \\
\hline $\mathrm{A} 2_{2}$ & $J 12 L 43$ & $6 / 6 / 2006$ & $1.0 E-01$ & $1.25 E+01$ & $5.3 \mathrm{E}+\infty 0$ & 6.00E-02 & $1.50 E-01$ \\
\hline A3 & J12L44 & $6 / 6 / 2006$ & $1.0 E-01$ & $\mid \frac{1.16 \mathrm{E}+01}{1.11 \mathrm{E}}$ & $6.1 \mathrm{E}+\infty 0$ & $3.15 \mathrm{E}-02$ & $5.00 \mathrm{E}-02$ \\
\hline $\mathrm{A4}_{4}$ & $J 12 L 45 / J 12 L 46$ & $6 / 6 / 2006$ & $1.0 \mathrm{E} \cdot 01$ & $1.11 E+01$ & $11.37 E+01$ & $7.75 \mathrm{E}-02$ & $5.95 E-02$ \\
\hline
\end{tabular}

18

20 Statistical Computations

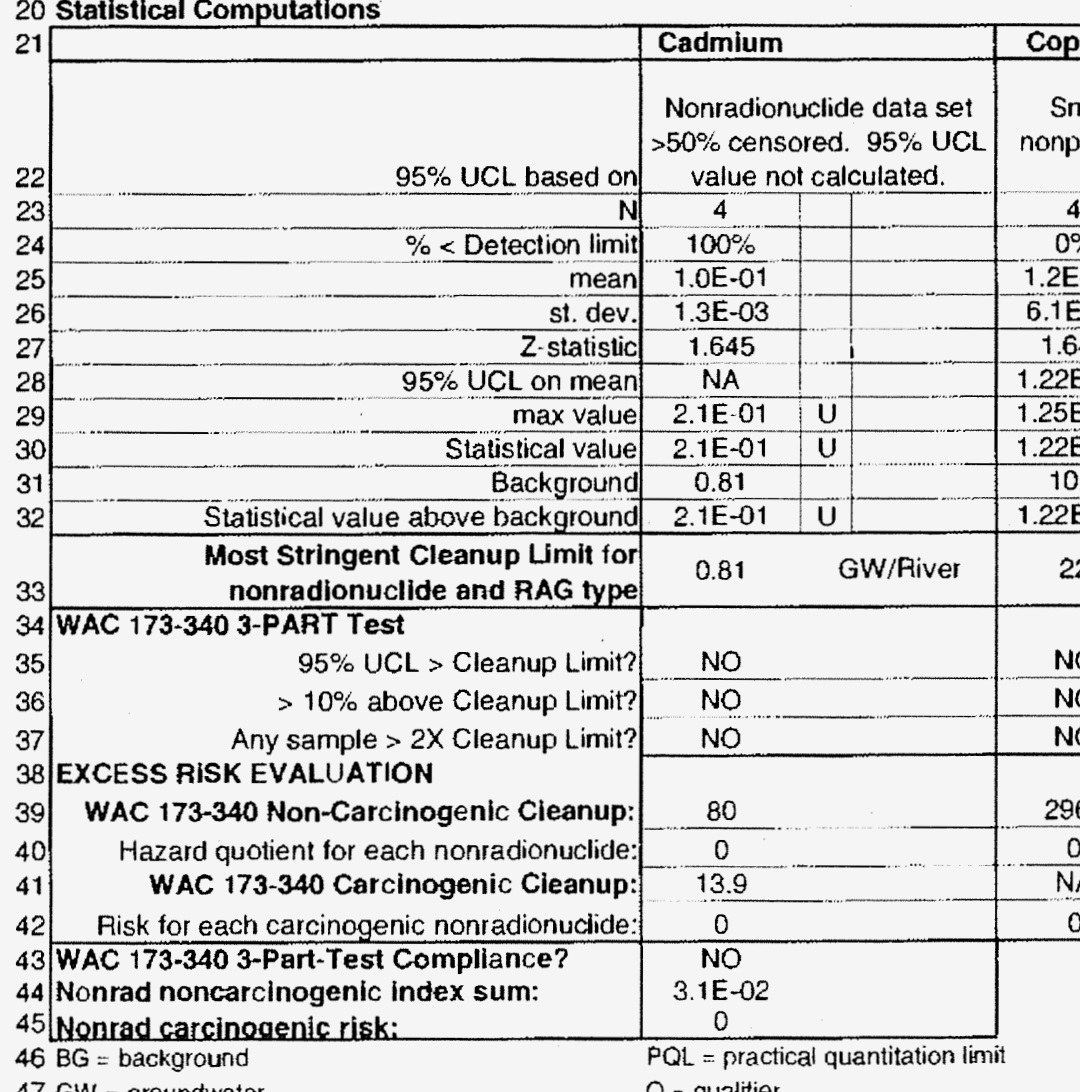

$47 \mathrm{GW}=$ groundwater

$49 \mathrm{MDA}=$ minimum detectable activity
PQL = practín

$\mathrm{O}=$ = qualitier
RAG $=$ remediat action goal
Copper 1 Lead

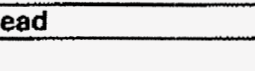

\section{Small data set. Use
nonparametric z-statistic}

$\frac{4}{0 \%}$

\begin{tabular}{r|}
$7.5 \mathrm{E}+\infty$ \\
$4.1 \mathrm{E}+00$ \\
1.645
\end{tabular}

\begin{tabular}{|c|c|}
\hline $4.1 \mathrm{E}+00$ \\
\hline 1.645 \\
\hline $1.09 \mathrm{E}+01$
\end{tabular}

$\left|\begin{array}{c}1.09 E+01 \\ 1.88 E+01 \\ 1.09 E\end{array}\right|$

$\frac{1.09 E+01}{10.2}$

$1.09 \mathrm{E}+01:$

Cobalt-60

Cesium-137

Small data set. Use
nonparametric z-statistic.

$\frac{4}{100 \%}$

$7.1 E-02$

$\frac{1.645}{9.97 \mathrm{E}-02}$ $\frac{\mid 2.30 E-01}{N A}$

\begin{tabular}{|c|c|c|c|}
\hline 22 & BG/River & 10.2 & GW/River \\
\hline No & & YES & \\
\hline
\end{tabular}

NO

NO $\quad$ YES

\begin{tabular}{l|l} 
NO & NO \\
\hline
\end{tabular}

\begin{tabular}{l|l}
2960 & 353 \\
\hline 0 &
\end{tabular}

\begin{tabular}{|l|l|}
\hline 0 & $3.1 \mathrm{E}-02$ \\
\hline $\mathrm{NA}$ & $\frac{N A}{2}$ \\
\hline
\end{tabular}

$U=$ undetected

WAC $=$ Washington Administrative Code

\begin{tabular}{c}
4 \\
$75 \%$ \\
\hline
\end{tabular}

\begin{tabular}{c|c|c|}
\hline & 4 \\
\hline & $100 \%$ \\
\hline
\end{tabular}

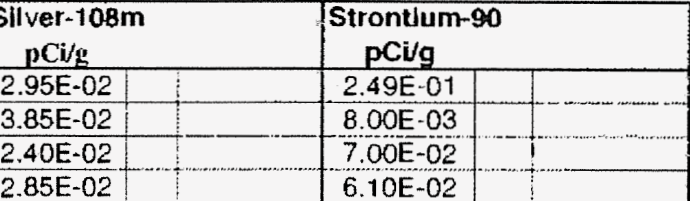

nonparametric 2 -statistic.

nonparametnic z-statistic.

\begin{tabular}{|c|c|}
4 \\
\hline$-75 \%$ \\
\hline 0.75
\end{tabular} $-\frac{75 \%}{9.7 \mathrm{E}-02}$ $1.0 \mathrm{E}-01$
1.645
$1.83 \mathrm{E}-01$ 


\section{Washington Closure Hantor}

Originator M. J. Appel $m g x$

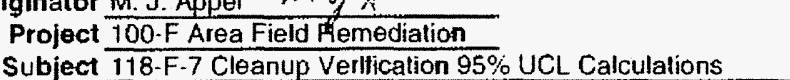

CALCULATION SHEET

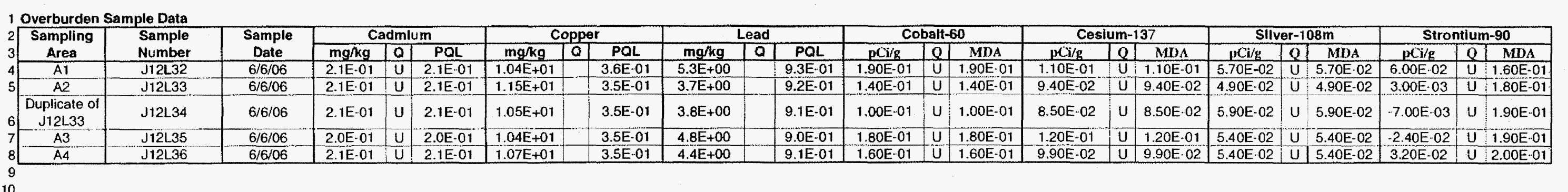
9
10
11 stall

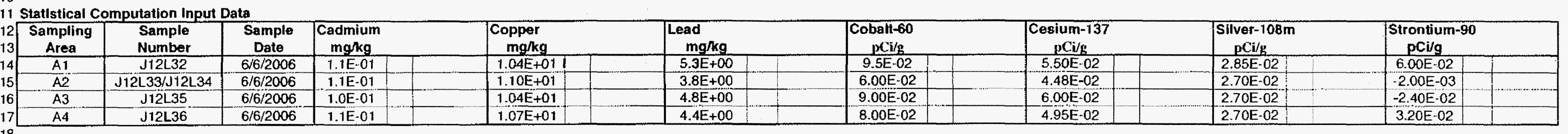
18

20 Statistical Computations

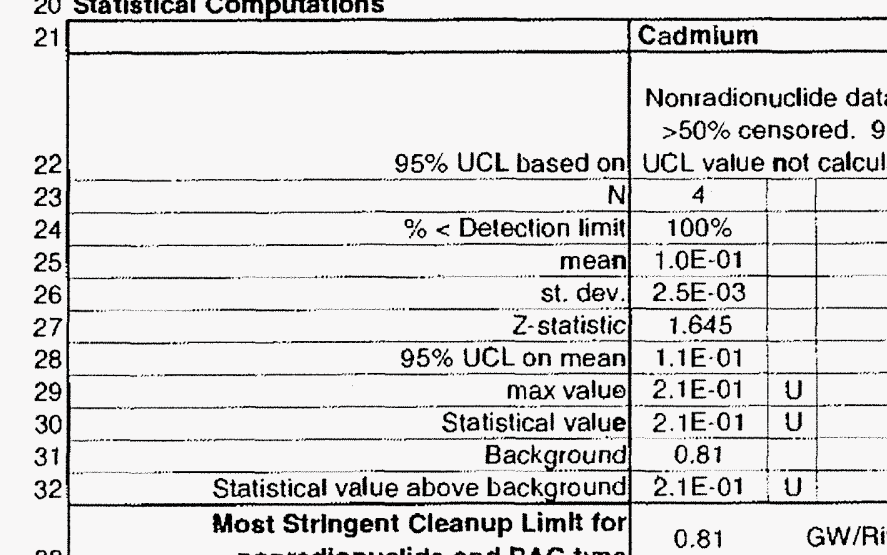

33 Mac 173-340 3-PAART Test

$95 \% \mathrm{UCL}>$ Cleanup Limit? NO

36 Ans $>10 \%$ above Cleanup Limit? $N$

Any sample $>2 X$ Cleanup Limit?
38 EXCESS RISK EVALUATION

9. WAC 173-340 Non-Carcinog

40 Hazard quotient for each nonradionuclide:

WAC 173-340 Carcinogenic Cleanu

nonradionuclide:

WAC 173-340 3-Part-Test

Index sum:

45 Nonrad carcinogenic rist:

$46 \mathrm{BG}=$ background
$47 \mathrm{GW}$ - groundwater

$48 \mathrm{NA}$ - ground applicable

$49 \mathrm{MDA}=$ minimum detectable activity

YES

VES values all cadmium

\begin{tabular}{l|l} 
because all copper values & $\begin{array}{l}\text { Because all lead values ar } \\
\text { beckground }(0.81 \mathrm{mg} / \mathrm{kg})\end{array}$ \\
are below background (22) background (10.2
\end{tabular}

calcuiation of excess

\begin{tabular}{|l|l|l|}
\hline excess risk is not required. & excess risk is not required. \\
\hline
\end{tabular}

$\mathrm{LL}=$ practical quantitation limit $\quad U$ - undetecled

RAG $=$ remedial action goal

$U C L=$ upper contidence limit

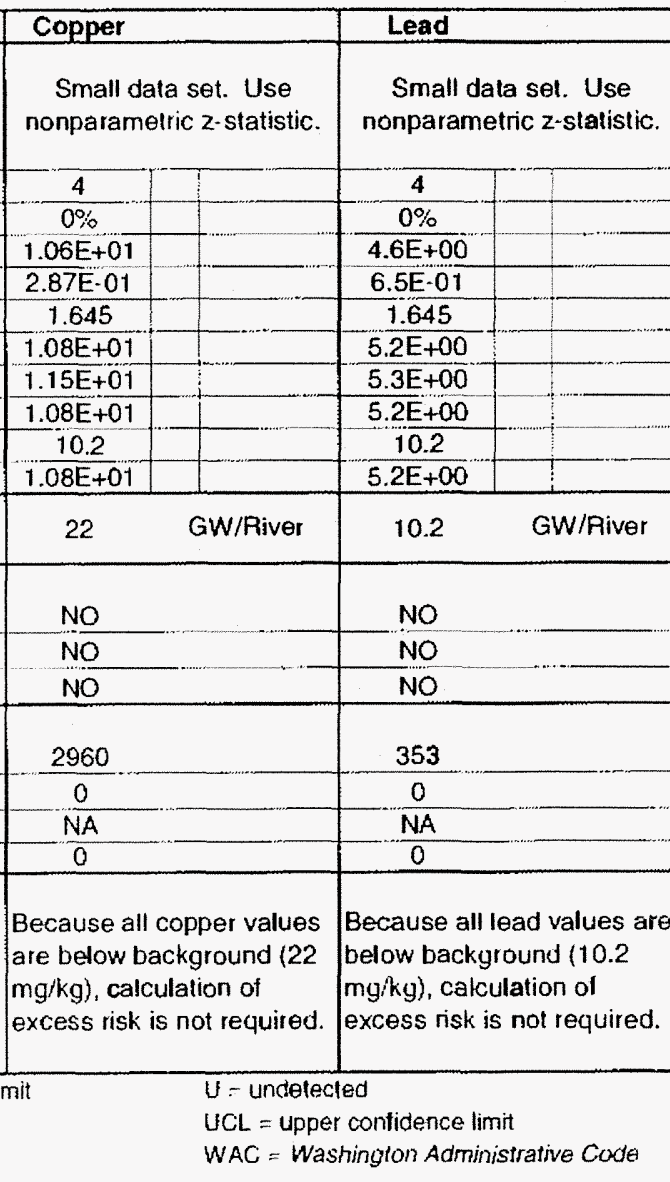


Washington Closure Hanford

Originator M. J. Appel $m g f$

Project 100-F Alea Field Rémediation

95\% UCL Calculations

Date 977106
Job No. 14655
Calc. No. 0100 F-CA-V0269
Checked $\frac{\text { T. M. Blakley frad }}{2}$
Rev. No. $\frac{0}{\text { Date }}$
Sheet No. $\frac{914106}{6 \text { of } 9}$
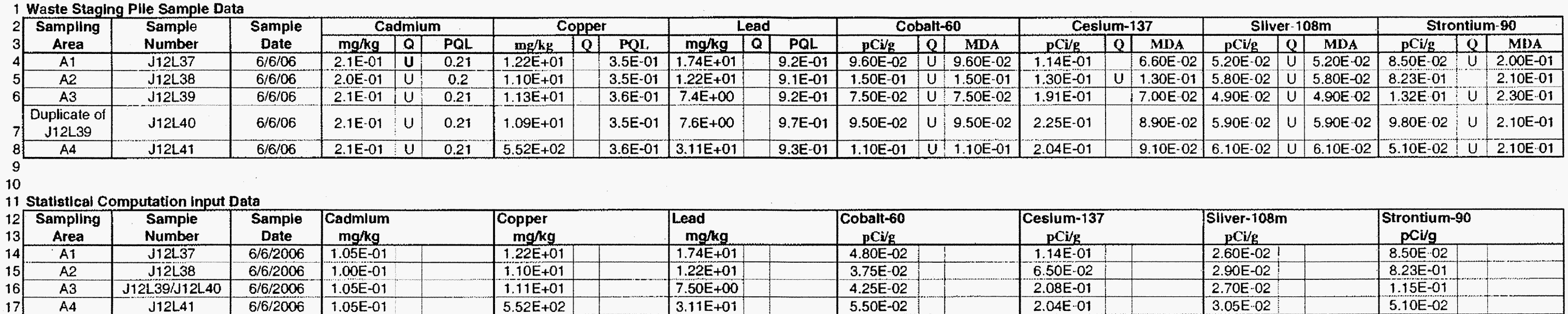
18

19
20
2 Statistical Computations

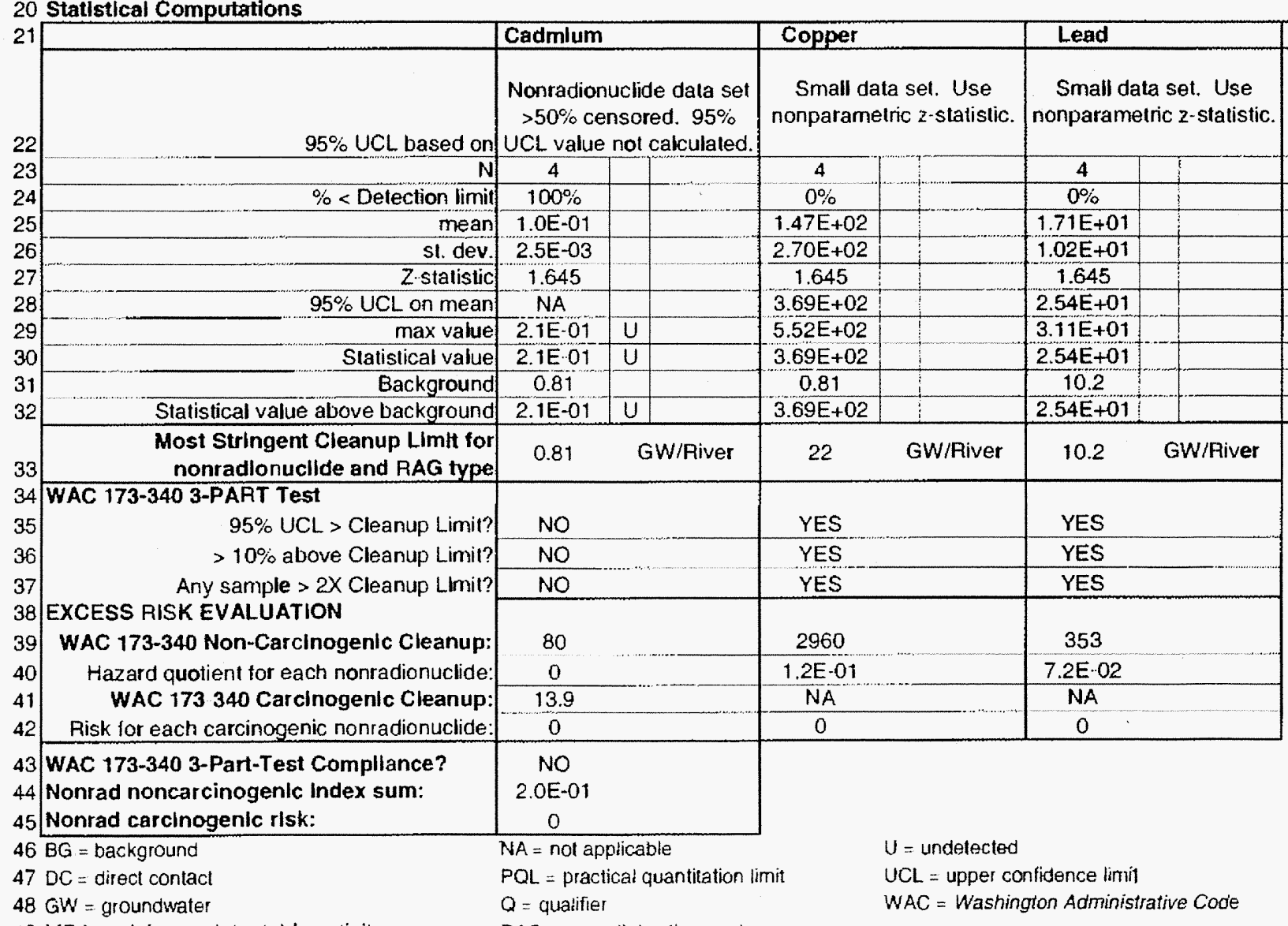


CALCULATION SHEET

Washington Closure Hanford

Originator M. J. Appel $M / Q 7$

Project 100-F Area Field Peemediation

Subject $118-F-7$ Cleanup Verification $95 \%$ UCL Calculation

Spllt-Duplicate Analysis

Shallow Zone Sample Results:

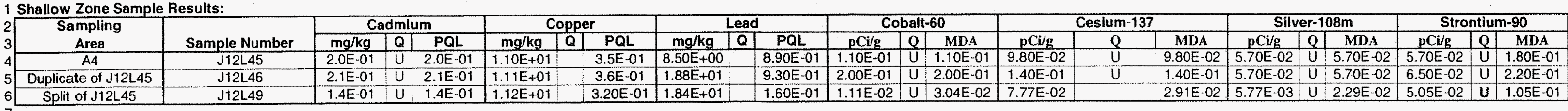

5 Duplicate of J12L

8 Sample Analysis:

\begin{tabular}{|c|c|c|c|c|c|c|c|c|}
\hline 15: & & $\overline{0.2}$ & 1 & 5 & 0.05 & 0.1 & 0.1 & 1 \\
\hline \multirow{3}{*}{ Duplicate Analysis } & Both $>$ PQL or MDA? & No-Stop (acceptable) & Yes (continue) & Yes (contlnue) & No-Stop (acceptable) & No-Stop (acceptable) & No-Stop (acceptable) & No-Stop (acceptable) \\
\hline & Both $>5 \times \mathrm{TDL} ?$ & & Yes (calc RPD) & No-Stop (acceptable) & & & & \\
\hline & $\frac{\mathrm{APD}}{\mathrm{Both}>\mathrm{PQL}}$ & No-Stop (acceptable) & $\begin{array}{c}0.9 \% \\
\text { Yes (continue) }\end{array}$ & Yes (continue) & No-Stop (acceptable) & No-Stop (acceptable) & No-Stop (acceptable) & No-Stop (acceptable) \\
\hline Split Analysis & Both > 5xTDL? & & Yes (calc RPD) & No-Stop (acceptable) & & & & \\
\hline
\end{tabular}

16 Note: The significance of the reported RPD values, including values greater than $30 \%$, is addressed within the Data Quality Assessment tor the Cleanup Verficcation Package for this site.

$17 \mathrm{~B}=$ analyte found in method blank

$18 \mathrm{PA}=$ minh detable $\mathrm{APD}=$ relative percent differer

$20 \mathrm{Q}=$ qualifier
Date $9 / 706$

Job No. 14655

Calc. No. 0100F-CA-V0269

T.M. Blakley $\ln 0$

$\mathrm{U}=$ undetected
Rev. No. $\frac{0}{\text { Date }} \frac{0}{\$ / 7+1 / 0_{6}}$ 


\section{Washington Closure Hanford}

Originator M. J. Appel

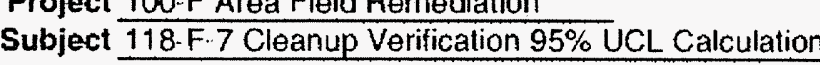

Split-Duplicate Analysis

1 Overburden Sanalysis

\begin{tabular}{|c|c|c|c|c|c|c|c|c|c|c|c|c|c|c|c|c|c|c|c|c|c|}
\hline \multirow{2}{*}{$\begin{array}{c}\text { Samplling } \\
\text { Area }\end{array}$} & \multirow[b]{2}{*}{ Sample Number } & \multicolumn{3}{|c|}{ Cadmlum } & \multicolumn{2}{|c|}{ Copper } & \multicolumn{3}{|c|}{ Lead } & \multicolumn{3}{|c|}{ Cobalt-60 } & \multicolumn{3}{|c|}{ Ceslum-137 } & \multicolumn{3}{|c|}{ Sllver-108m } & \multicolumn{3}{|c|}{ Strontlum-90 } \\
\hline & & $\mathrm{mg} / \mathrm{kg}$ & Q & PQL & $\mathrm{mg} / \mathrm{kg}$ & {$[0]$} & $\mathrm{mg} / \mathrm{kg}$ & का & $\overline{P Q L}$ & $\overline{\mathrm{pCi} / \mathrm{g}}$ & $\bar{Q}$ & $\overline{M D A}$ & pCi/g & $Q$ & MDA & $\mathrm{pCi} / \mathrm{g}$ & 0 & MDA & & (a) & MDA \\
\hline $\mathrm{A} 2^{2}$ & $J 12 L 33$ & $2.1 \mathrm{E}-01$ & $\mathrm{U}$ & $2.1 \mathrm{E} \cdot 01$ & $1.15 \mathrm{E}+01$ & $3.5 \mathrm{E}-01$ & $3.7 \mathrm{E}+00$ & & $9.2 \mathrm{E}-01$ & $1.40 \mathrm{E}-01$ & $U$ & $1.40 \mathrm{E}-01$ & $9.40 \mathrm{E}-02$ & & $9.40 \mathrm{E}-02$ & $4.90 \mathrm{E}-02$ & & $4.90 \mathrm{E}-02$ & E.03 & U & $1.80 \mathrm{E}-01$ \\
\hline Duplicale of J12L33 & J12L34 & $2.1 \mathrm{E}-01$ & & $2.1 E-01$ & $1.05 E+01$ & $3.5 \mathrm{E}-01$ & $3.8 \mathrm{E}+00$ & & $9.1 \mathrm{E}-01$ & $1.00 \mathrm{E}-01$ & $U$ & $1.00 \mathrm{E}-01$ & $8.50 \mathrm{E}-02$ & $u$ & $8.50 \mathrm{E}-02$ & $5.90 \mathrm{E}-02$ & u & $5.90 \mathrm{E}-02$ & $7.00 \mathrm{E}-03$ & U & $1.90 \mathrm{E}-01$ \\
\hline Split of J12L33 & $J 12\llcorner 47$ & $1.4 \mathrm{E}-01$ & UN & $1.4 \mathrm{E}-01$ & $1.23 E+01$ & $3.20 \mathrm{E}-01$ & $4.0 \mathrm{E}+00$ & & $1.6 \mathrm{E}-01$ & $6.85 \mathrm{E}-03$ & $u$ & $2.00 \mathrm{E}-02$ & $4.12 \mathrm{E}-03$ & $u$ & $1.88 \mathrm{E}-02$ & $1.05 \mathrm{E}-03$ & u & $1.29 \mathrm{E}-02$ & $92 \mathrm{E}-03$ & $\mathrm{u}$ & $1.36 \mathrm{E}-01$ \\
\hline
\end{tabular}

7

Date $9 / 7 / 06$

Job No. 1465

-
Calc. No. 0100F.CA-V0269

$\ln B$
Rev. No.

V. No. 0

Date $\frac{9 / 14 / 06}{8 \text { of } 9}$

\begin{tabular}{|c|c|c|c|c|c|c|c|c|}
\hline & & & & \\
\hline \multirow{3}{*}{\begin{tabular}{l|l}
0 & Duplicale Analysis \\
1 & Dicis \\
\end{tabular}} & Both > PQL or MDA? & No-Stop (acceptable) & Yes (continue) & Yes (continue) & No-Stop (acceptable) & No-Stop (acceptable) & No-Stop (acceptable) & No Stop (acceptable) \\
\hline & Both $>5 \times T D L ?$ & & Yes (calc RPD) & No-Stop (acceptable) & & & & \\
\hline & RPD & & $9.1 \%$ & & & & & \\
\hline \multirow[b]{2}{*}{ Split Analysis } & Both > PQL? & No-Stop (acceptable) & Yes (contlnue) & Yes (continue) & No-Stop (acceptable) & No-Stop (acceptable) & No-Stop (acceptable) & No-Stop (acceptable) \\
\hline & Both > 5xTDL? & . & Yes (calc RPD) & No-Stop (acceptable) & & & & \\
\hline
\end{tabular}

16 Note: The significance of the reported RPD values, including values greater than

$17 \mathrm{~B}=$ analyte found in method blank

$18 \mathrm{MDA}=$ minimum detectable activily

$19 \mathrm{~N}=$ Spiked analyte recovery is

$Q=$ qualifier

$\mathrm{RPD}=$ relative percent difterence

$\mathrm{TDL}=$ target detection limi
$U:=$ undetected 
CALCULATION SHEET

\section{Washington Closure Hanford}

Originator M.J.Appel mil A

Project 100. Apel

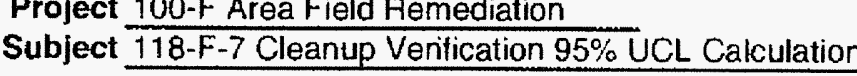

Date $9 / 7 / 06$
Job No. $\frac{9655}{14655}$

Job No. 1465
Calc. No. 0100F-CA-V0269 Checked T.M. Blakley
Rev. No. $\quad 0$

Date $\frac{0}{\frac{9+404}{909}}$

Spilt-Duplicate Analysis

\begin{tabular}{|c|c|c|c|c|c|c|c|c|c|c|c|c|c|c|c|c|c|c|c|c|c|c|}
\hline \multirow{2}{*}{\begin{tabular}{|c|c|}
$\begin{array}{c}\text { Sampling } \\
\text { Area }\end{array}$ \\
$A 3$
\end{tabular}} & \multirow[b]{2}{*}{ Sample Number } & \multicolumn{3}{|c|}{ Cadmium } & \multicolumn{3}{|c|}{ Copper } & \multicolumn{3}{|c|}{ Lead } & \multicolumn{3}{|c|}{ Cobalt-60 } & \multicolumn{3}{|c|}{ Ceslum-137 } & \multicolumn{3}{|c|}{ Sllver-108m } & \multicolumn{3}{|c|}{ Strontium-90 } \\
\hline & & $\mathrm{mg} / \mathrm{kg}$ & a & $\mathrm{PQL}$ & $\mathrm{mg} / \mathrm{kg}$ & Q & $\mathrm{POL}$ & $\mathrm{mg} / \mathrm{kg}$ & Q. & $\mathrm{POL}$ & $\mathrm{pCi} / \mathrm{g}$ & Q & MDA & $\mathrm{pCi} / \mathrm{g}$ & $Q$ & MDA & $\mathrm{pCi} / \mathrm{g}$ & Q & MDA & $\mathrm{pCi} / \mathrm{g}$ & Q1 & MDA \\
\hline & J12L39 & 0.21 & $u$ & 0.21 & $1.13 \mathrm{E}+01$ & & 0.36 & 7.4 & & 0.92 & $7.50 \mathrm{E}-02$ & $\vec{u}$ & $7.50 \mathrm{E}-02$ & $1.91 \mathrm{E}-01$ & & $7.00 \mathrm{E}-02$ & $4.90 \mathrm{E}-02$ & U & $4.90 \mathrm{E}-02$ & $1.32 \mathrm{E}-01$ & $\vec{U}$ & 01 \\
\hline Duplicate of J12L39 & $J 12 L 40$ & 0.21 & $\mathrm{u}$ & 0.21 & $1.09 \mathrm{E}+01$ & & 0.35 & 7.6 & & 0.97 & $9.50 \mathrm{E}-02$ & $U$ & $9.50 \mathrm{E}-02$ & $2.25 \mathrm{E}-01$ & & $8.90 \mathrm{E}-02$ & $5.90 \mathrm{E}-02$ & $U$ & $5.90 \mathrm{E}-02$ & $9.80 \mathrm{E}-02$ & $u$ & $2.10 \mathrm{E}-01$ \\
\hline Split of J12L39 & $J 12 L 48$ & 0.14 & UN & 0.14 & $1.04 E+01$ & & 0.32 & 7.6 & & 0.16 & $2.77 \mathrm{E}-03$ & $u$ & $2.51 \mathrm{E}-02$ & $1.63 \mathrm{E}-01$ & & $2.16 \mathrm{E}-02$ & $2.72 \mathrm{E}-03$ & $u$ & $1.72 \mathrm{E}-02$ & $1.57 \mathrm{E}-01$ & & $1.03 E-01$ \\
\hline
\end{tabular}

\section{Sample Analysls:}

\begin{tabular}{|c|c|c|c|c|c|c|c|c|}
\hline & $\pi$ & 0.2 & 1 & 5 & 0.05 & 0.1 & 0.1 & 1 \\
\hline \multirow[b]{2}{*}{ Duplicate Analysis } & Both $>$ PQL or MDA? & No-Stop (acceptable) & Yes (continue) & Yes (continue) & No-Stop (acceptable) & Yes (continue) & No-Stop (acceptable) & No-Stop (acceptable) \\
\hline & $\begin{array}{c}\text { Both > 5 5 TDL? } \\
\text { RPD }\end{array}$ & & Yes (calc RPD) & No-Stop (acceptable) & & No-Stop (acceptable) & & \\
\hline \multirow[b]{2}{*}{ Split Analysis } & Both $>$ PQL? & No-Stop (acceptable) & Yes (continue) & Yes (continue) & No-Stop (acceptable) & Yes (continue) & No-Stop (acceptable) & No-Stop (acceptable) \\
\hline & Both $>5 \times$ TDL? & & Yes (calc RPD) & No-Stop (acceptable) & & No-Stop (acceptable) & & \\
\hline
\end{tabular}

16 Note: The significance of the reported RPD values, including values greater than $30 \%$, is addressed within the Data Quality Assessment for the Cleanup Venfication Package for this site.

$17 \mathrm{~B}=$ analyte found in method blank

RPD = relative percent difference

$19 \mathrm{~N}=$ Spiked analyte recovery is outside stated control limits $\quad \mathrm{TLL}=$ target detection limit

$U=$ undetected 


\section{DISTRIBUTION}

U.S. Department of Energy

Richland Operations Office

D. C. Smith (5)

A3-04

DOE-RL Public Reading Room

$\mathrm{H} 2-53$

Fluor Hanford, Inc.

J. P. Shearer (WIDS)

A0-21

Washington Closure Hanford

M. T. Hughes

$\mathrm{H} 4-23$

M. J. Appel

$\mathrm{H} 4-23$

M. A. Buckmaster

X9-07

S. W. Callison

$\times 9-07$

R. A. Carlson

$\mathrm{X} 4-08$

S. W. Clark

$\mathrm{H} 4-23$

J. S. Decker

X4-08

L. A. Dietz

$\mathrm{H} 4-22$

L. M. Dittmer

$\mathrm{H} 4-23$

J. E. Thomson

$\mathrm{H} 4-22$

Document Control

H4-11

Hanford Technical Library

P8-55 
CVP-2006-00007

Rev. 0

Distr-2 